Acta Theriologica 42 (4): 399-451, 1997.

PL. ISSN 0001-7051

\title{
Factors shaping population densities and increase rates of ungulates in Bialowieża Primeval Forest (Poland and Belarus) in the 19th and 20th centuries
}

\author{
Bogumiła JĘDRZEJEWSKA, Włodzimierz JĘDRZEJEWSKI,
}

\author{
Aleksei N. BUNEVICH, Lech MIŁKOWSKI and Zbigniew A. KRASIŃSKI
}

Jędrzejewska B., Jędrzejewski W., Bunevich A. N., Mitkowski L. and Krasiński Z. A. 1997. Factors shaping population densities and increase rates of ungulates in Bjałowieza Primeval Forest (Poland and Belarus) in the 19th and 20th centuries. Acta Theriologica 42: 399-451.

Population dynamics of ungulates (European bison Bison bonasus, elk Alces alces, red deer Cervus elaphus, roe deer Capreolus capreolus, wild boar Sus scrofa, non-native fallow deer Dama dama, and cattle) were analysed in the Bialowieża Primeval Forest (BPF, $1250 \mathrm{~km}^{2}$ ), one of the largest remaining tracts of ancient mixed and deciduous forests in the lowlands of Europe. Forty percent of BPF belongs to Poland, and 60\% to the Belarus Republic. Polish and Belarussian game departments inventories of ungulate numbers (1946-1993) and archival data on censuses and hunting statistics (1798-1940) are presented. The recorded ranges of densities of native wild ungulates were: European bison $0-1.5 \mathrm{inds} / \mathrm{km}^{2}$, elk $0-0.6$, red deer $0-5.4$, roe deer $0.6-4.8$, and wild boar $0.2-3.8$ ind $s / \mathrm{km}^{2}$. Fallow deer were introduced in 1890 (maximum density reached in 1914 was 1.2 inds $/ \mathrm{km}^{2}$ ) and were eradicated by 1920 . Cattle were traditionally pastured in the Forest, and its grazing impact was heaviest in 1880-1914 (maximum recorded density 6.7 inds $/ \mathrm{km}^{2}$ ). In $1798-1993$, the community of wild ungulates consisted of three to six species, with total densities varying from $<2$ to 14.4 inds $/ \mathrm{km}^{2}$ (65 to $1180 \mathrm{~kg}$ of crude biomass per $1 \mathrm{~km}^{2}$ ). Roe deer, wild boar, and red deer were usually the dominants. However, in 1860-1971, cattle constituted from $15 \%$ to $80 \%$ by numbers and from $37 \%$ to $87 \%$ by biomass of all ungulates in Bialowieża Forest.

Data on population trends within a five-species assemblage of native wild ungulates were subject to multiple regression analysis to determine the roles of predation (by wolves Canis lapus and lynxes Lynx $(y n x)$, competition, food, weather variables, and humans in shaping population densities and increase rates of ungulates. Growth of the mean annual temperature had positive effect on densities of all ungulates, probably through improving food supply and feeding conditions. Bison and elk were shaped by intra- and interspecific competition for food. Bison numbers have heen significantly limited by humans, due to both uncontrolled exploitation in years of political instability and deliberate culling in years of protection. Red deer and roe deer were primarily shaped by predation from wolves and lynx, respectively. Competition for food influenced red and roe deer when they had erupted after predator extermination. Wild boar was influenced predominantly by food availability, especially the highly variable crops of oak seeds.

Mammal Research Institute, Polish Academy of Sciences, 17-230 Bialowieża, Poland, e-mail: wlodek@bison.zbs.bialowieza.pl (BJ, WJ); State National Park Belovezhskaya Pushcha, Brest Oblast, Kamenec Raion, 225063 Kamenyuki, Belarus (ANB); 17-230 Bjałowieża, Krzyże 27, Poland (LM); Bialowieża National Park, 17-230 Bialowieża, Poland (ZAK)

Key words: temperate forests, predation, competition, climate, food supply, human impact, lynx, wolf, European bison, elk, red deer, roe deer, wild boar 


\begin{tabular}{lr}
\multicolumn{1}{c}{ Contents } & \\
Introduction & 400 \\
Study area & 402 \\
History of the status and occurrence of ungulates in Bialowieża Primeval Forest & 404 \\
Material and methods & 407 \\
Methods of inventories of ungulates in BPF & 407 \\
Human impact on ungulates & 409 \\
Numbers of wolves and lynxes & 409 \\
Weather variables & 410 \\
Indices of food abundance to ungulates & 410 \\
Statistical analysis & 410 \\
Results & 411 \\
Ctimatic conditions of Bialowieza Forest in the 19th and 20th centuries & 413 \\
Estimated numbers and population dynamics of ungulates & 412 \\
Community of ungulates in Bialowież Primeval Forest - changes in time & 417 \\
Factors affecting population densities and increase rates of wild ungulates & 420 \\
Discussion & 429 \\
Reliability of estimates and reconstructions of ungulate numbers & 429 \\
$\quad$ Multifactorial explanation of ungulate dynamies & 431 \\
References & 435 \\
Appendix I. Numbers of European bison in 1802-1993 & 440 \\
Appendix II. Numbers of elk in 1798-1993 & 441 \\
Appendix III. Numbers of red deer in 1750-1993 & 443 \\
Appendix IV. Numbers of roe deer in 1890-1993 & 445 \\
Appendix V. Numbers of wild boar in 1890-1993 & 447 \\
Appendix Vl. Numbers of introduced fallow deer in 1890-1935 & 450 \\
Appendix VII. Indices of cattle abundance in 1700-1992 & 450
\end{tabular}

\section{Introduction}

To draw reliable conclusions about the patterns and mechanisms of population change in ungulates, we need a series of data covering at least a few decades. For instance, Peterson et al. (1984) and McLaren and Peterson (1994) showed that 16-38-year cycles of numbers can occur in the natural population of moose Alces alces in the temperate-boreal forest of North America. But estimating the number of ungulates, especially those inhabiting forests, is a very difficult and laborious task (eg Pucek et al. 1975, Staines and Ratcliffe 1987, Aulak and Babińska-Werka 1990). In consequence, there are numerous long-term data on small rodents (eg Henttonen et al. 1987, Pucek et al. 1993), forest birds (eg Tomiałojć et al. 1984, Tomiałojć and Wesołowski 1994), but few such series on ungulate numbers (eg Peterson et al. 1984, Ratcliffe 1984, Putman and Sharma 1987, Gasaway et al. 1992).

Long series of data on ungulate abundance (inventories conducted as part of game management duties) are known from some countries of central and eastern Europe, where in old national parks, hunting preserves (eg in 'zapovedniks' in the 
former USSR) and forests of special significance, inventories of ungulates have been conducted for decades, sometimes since the 1930s (eg Filonov 1989). In exceptional cases, such as in the Białowieża Primeval Forest, they began in the end of the 18th century (Karcov 1903, Hartman 1939). However, because of the difficulty of applying critical analysis to such largely qualitative data, these series of records bave so far contributed very little to our understanding of the functioning of ungulates in the Holarctic region.

Factors that affect densities and population dynamics of ungulates have been investigated in North America (eg Messier 1991, Seip 1992), Africa (eg Sinclair and Norton-Griffiths 1982), Europe and Asia (eg Skogland 1985, Filonov 1989). Stimulated by interest in sustainable harvesting, rational management and protection, or basic ecological questions, numerous empirical studies had to cope with problems of appropriate time and spatial scale, and the counfounding variable of human impact ( $\mathrm{cf}$ Peek 1980). Most investigations were concerned with one or two factors. The role of predation was examined in North America (eg Gasaway et al. 1983, Van Ballenberghe and Ballard 1994) and Africa (Schaller 1972, Sinclair 1985), where local ungulate communities coexist with assemblages of predators. Importance of food and competition for ungulates was investigated in Africa and Europe (Coe et al. 1976, Bobek 1977, Dublin et al. 1990, Jędrzejewska et al. 1994).

Saether (1997) reviewed several studies on ungulates on four continents and concluded that their population dynamics were influenced by a combination of stochastic variation in the environment and population density, both acting through changes in life history traits of ungulates. According to Putman et al. (1996) density-independent factors (eg climate) primarily influence mortality level of ungulates, whereas effects of density are particularly manifest in changing recruitment rates. It must be noted, however, that both Saether (1997) and Putman et al. (1996) analysed the studies done in predator-free environments.

In Europe, the functioning of ungulate communities has long been shadowed by the destructive impact of humans. The main vectors of human disturbance were pointed at ungulates, their ancestral habitats (forests), and large predators. In this respect, Białowieża Primeval Forest, located on the Polish-Belarussian borderland, provides invaluable opportunity of insight into the forest-ungulate-predator relationships. One of the best preserved forests of its size, Bialowieża survived with Europe's richest community of ungulates that includes European bison Bison bonasus, elk Alces alces, red deer Cervus elaphus, roe deer Capreolus capreolus, and wild boar $S u s$ scrofa, coexisting with their predators, the wolf Canis lupus and the Iynx Lynx lynx.

This paper is an attempt to reconstruct and analyse long-term data on ungulate abundance. Inventories of ungulates (first of bison, only) began here at the end of the 18th century and have been conducted to now, generally by the same methods based on snowtracking. Moreover, the drive censuses were conducted several times from 1950-1994, concurrently with the traditional snowtracking methods. This gave the opportunity to verify and interpret the results of previous snowtracking 
surveys. We present here a 200-year series of population data on European bison, elk, and red deer, and 100-year data on roe deer and wild boar numbers. All information available on intensity of cattle grazing in Białowieża Forest during the last two centuries is also given. Then, we also present the synthesis of documentary data on numbers and population dynamics of wolves (from Jędrzejewska et al. 1996), and lynxes (from Jędrzejewski et al. 1996), as well as weather variables and indices of food resources. We aimed at elucidating and quantifying the roles of humans, wolf and lynx predation, climate, and food resources in shaping the numbers and population trends of bison, elk, red deer, roe deer, and wild boar in the 19th and 20th centuries.

\section{Study area}

Białowieża Primeval Forest (BPF, 52 $30^{\prime}-53^{\circ} \mathrm{N}, 23^{\circ} 30^{\prime}-24^{\circ} 15^{\prime} \mathrm{E}$ ) is a vast woodland connected by continuous forests with other large forest tracts (Ruzhana Forest in $\mathrm{NE}$, Shereshevo Forest in SE, Knyszyn Forest in NW) (Fig. 1). It lies in the zone of temperate deciduous and mixed forests, and is composed of rich multispecies tree stands. In its historical borders, BPF covers $1250 \mathrm{~km}^{2}$ but in recent. decades its administrative coverage has increased to nearly $1500 \mathrm{~km}^{2}$ due to acquisition (in both Polish and Belarussian parts) of peripheral woods and woodlots, mostly of secondary origin.

From the 15 th to the end of 18 th century, BPF was protected as the royal hunting forest of Polish kings and Lithuanian dukes. In the 19th century and until 1914 (under Russian rule), it became a protected forest for monarchial hunts of the Russian tsars. Industrial exploitation of timber in BPF was begun in 1915 (during World War I) by German occupants. After WW I, the Polish state forestry and the English company The Century European Timber Corporation continued exploitation. In 1921, the most valuable and nearly untouched oldgrowth located in the heart of BPF was proclaimed the Biatowieża National Park. The remaining part of BPF underwent economic exploitation of timber until 1941.

In 1945, the new state border between Poland and the Soviet Union (Belarussian SSR) divided the BPF into two parts (Fig. 1) with different management rules. Since 1981, when the Soviets built a 2.5-m high wire fence along the border, it has been an actual barrier to ungulate movements. The Polish part of BPF $\left(580 \mathrm{~km}^{2}\right)$ includes Bialowieża National Park (BNP) and the exploited forests administered by the State Forestry. BNP $\left(47.5 \mathrm{~km}^{2}\right)$ is a strict nature reserve where no hunting, timber exploitation or motor transportation is allowed. The rich deciduous tree stands dominated by oak Quercus robur, lime Tilia cordata, and hornbeam Carpinus betulus cover 48\% of the Park's area. A mixed coniferous forest dominated by pine Pinus silvestris and spruce Picea abies (with admixtures of oak) cover 17\%, and wet alder Alnus glutinosa and ash Fraxinus excelsior forests $18 \%$. The average age of tree stands is 130 years. In the 1970s, the Park became one of UNESCO's Man \& Biosphere Reserves and World Heritage Sites. In 1996, BNP was expanded to cover $100 \mathrm{~km}^{2}$. The exploited forests on the Polish side of the border are managed by means of small clearcuts (0.1-6 ha) and selective cutting of large trees, and replantation. Mixed coniferous forests dominated by pine and spruce (with admixtures of oak) cover $54 \%$ of the area of exploited forest, alder and ash forests $20 \%$. and oak-lime-hornbeam forests $13 \%$. The average age of tree stands is 72 years. The Belarussian part of BPF $\left(870 \mathrm{~km}^{2}\right)$ has been partially protected since 1945 . Cutting is small and selective (ciead and dying trees only, no clearcuts). Coniferous forests dominated by pine and mixed coniferous forests composed of pine and spruce (with admixtures of oak) cover $69 \%$ of the area, oak-lime-hornbeam forests $6 \%$, and wet alder-ash forests $16 \%$. The average age of tree stands is 100 years. In 1991, the whole Belarussian part of BPF became a State National Park iwith some strict reserves but mostly with a partial protection regime) and UNESCO's Man \& Biosphere Reserve. More information about 

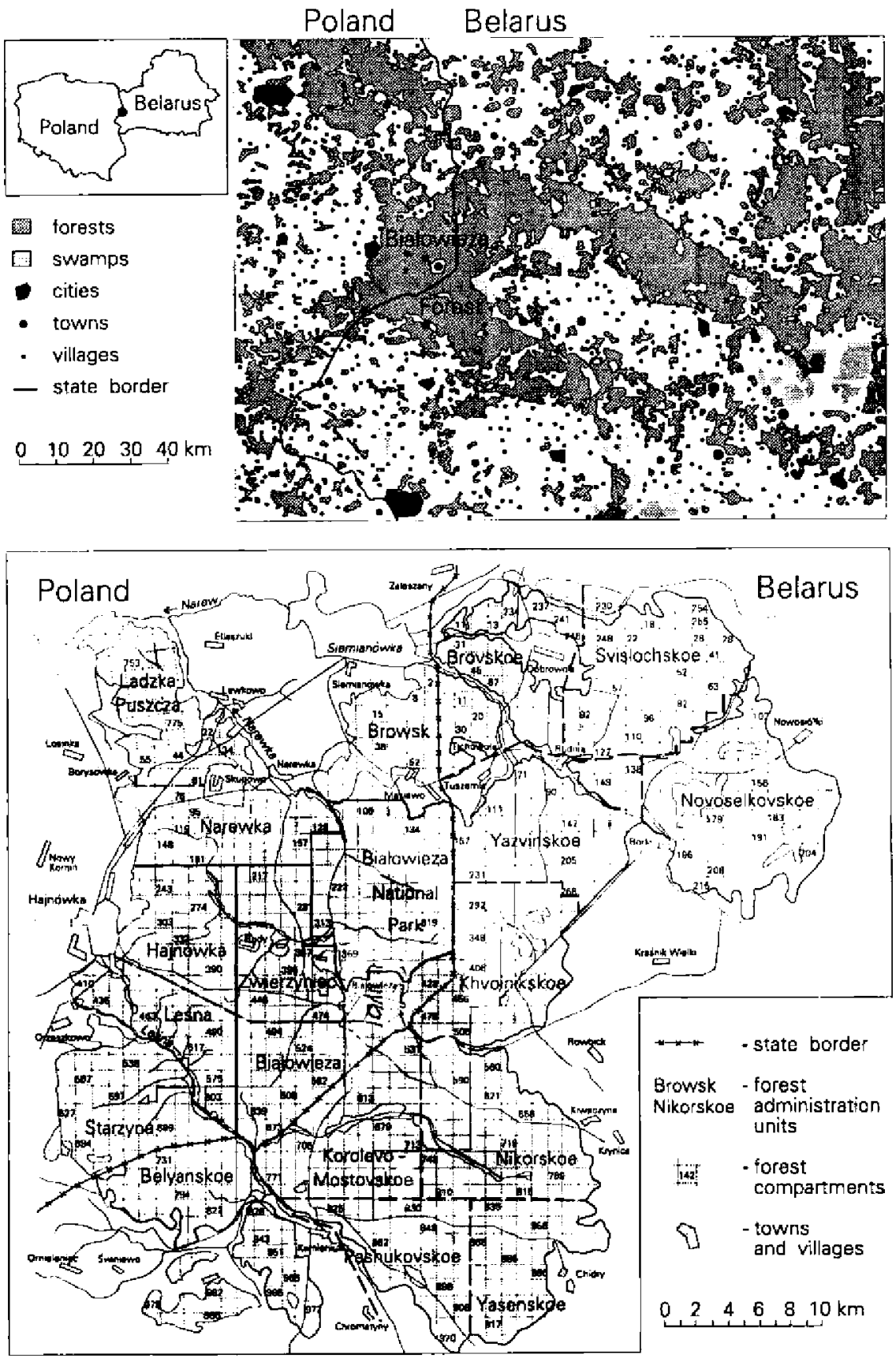

Fig. 1. Upper panel: Bialowieża Primeval Forest among woodlands of eastern Poland and western Belarus. Lower panel: schematic map of BPF with division into forest administration units (names) and forest compartments (small squares, some of them are numbered as examples). 
the vegetation of BPF is given by Falinski (1986). Further details on forest structure can be found in Jẹdrzejewska et al. (1994) and Jędrzejewski and Jędrzejewska (1995). Nowadays. BPF harbours two species of large predators, the lynx and the wolf. The native brown bear Ursus arctos was exterminated in the 2nd half of the 19th century. Few reintroduced bears lived in BPF from 1938 till 1950 (Buchalczyk 1980, Jędrzejewska et al. 1995). Average density of human population in BPF is 2-3 people/ $/ \mathrm{km}^{2}$.

\section{History of the status and occurrence of ungulates in Białowieża Primeval Forest}

In BPF, bison, elk, and red deer had a status of royal game and were protected since the 15 th century. The protection had economical and strategical purposes of keeping the reserves of food for the maintenance of the court and for special occasions. For instance, in 1409, "Whadystaw [Jagielto], King of Poland, enjoying the hunt in Biatowieża for eight days, had killed a great quantity of game. which, salted in barrels, was floated by the Narew and Vistula rivers to Plock, as a supply ready for the future war," wrote Jan Dlugosz, the chronicler (this and further translations by BJ). Since 1518 , again and again the monarchs reminded the administrators of BPF, "not to hunt and not to allow anyone to hunt" for bison, elk, and red deer. The privilege to hunt bison remained with kings, who rarely allowed magnates to kill few individuals (eg in 1577, Stefan Batory granted permissions to dises Radziwill and Zamojski to hunt four bison each). Royal hunts for bison were irregular (at few to several year intervals with some longer breaks). The method of hunts had not changed much from the 16th to the 19th century (Hussovianus 1523, Karcov 1903; the first described and the last such hunts occurred in 1504 and 1860, respectively). A large fenced enclosure (wooden fences supported by strong hemp nets) of a few square kilometers was built in the central part of BPF. For several days before the hunt, bison and all kinds of medium-sized and large game were driven to it by hundreds of peasants directed by the local forest administration officers. During one of the most spectacular hunts (in 1752), 42 bison were killed (Table 1).

Also, the traditional land management in BPF was very favourable for bison. From at least the 15 th century, abundant and rich wet meadows along rivers in the Forest were scythed by local people for hay. For centuries, this practice has prevented the encroachment of the forest into these grasslands, and improved grazing conditions for bison. The local administration of BPF deliberately left some stacks of hay in meadows for bison, the practice, which an official correspondence from 1802 mentioned as very old duty of game wardens (Hartman 1939). Two common species, wild boar and roe deer were exploited sustainably by the local inhabitants (Hedemann 1939).

Parallel to formal measures of game protection, a number of practical measures were also undertaken by the kings. Already in the early 16 th century, BPF had a well established local administration and about 200 guards which had been settled in small villages around the Forest. This professional forest and game service, with hereditary posts, was investitured a few times with land; eg in 1639 by king Whadyslaw IV Waza and in 1744 by August III Saxon (Hedemann 1939). This system of protection temporarily broke down during times of wars and political turmoil (eg in 1655-1660, 1700-1710; Hedemann 1936). Nonetheless, until the third partition of Poland in 1795, it was an efficient barrier against colonisation and uncontrolled exploitation of forest resources. The class of forest and game wardens, located in the social hierarchy higher than villeins and endowed with many privileges, had personal interest in protecting the Forest against the incursions of the third parties.

By the end of the 18th century, Poland lost independence. During the first two decades of Russian rule, BPF suffered from uncontrolled exploitation of timber and slaughter of game by poachers. A huge forest fire in 1811, a passage of Napoleon's army in 1812, and a Polish national insurgence in 1830-1831 were the most important factors moulding the character of BPF in the first half of the 19 th century (Więcko 1984). Game (except for bison) was heavily exploited by the local forest service, 
Table 1. Results of monarchial hunts in 1752-1902 and estimates of ungulate numbers. Data for 1860-1902 from Karcov (1903), and for 1752 from a sandstone obelisk built in Bialowieża village after the hunt. afallow deer were brought to Bialowieza for the hunt from the nearby private captive breeding center; ${ }^{b}$ approximate numbers interpolated between censuses in 1893 and 1896.

\begin{tabular}{|c|c|c|c|c|c|c|c|c|c|}
\hline \multirow{2}{*}{$\begin{array}{l}\text { Year } \\
1752\end{array}$} & \multicolumn{2}{|c|}{$\begin{array}{c}\text { Number of hunted } \\
\text { ungulates and estimated } \\
\text { population size }\end{array}$} & \multirow{2}{*}{$\begin{array}{r}\text { Bison } \\
\\
-. \\
42\end{array}$} & \multirow{2}{*}{$\begin{array}{r}\text { Elk } \\
\\
13\end{array}$} & \multirow{2}{*}{$\begin{array}{r}\begin{array}{r}\text { Red } \\
\text { deer }\end{array} \\
0 \\
0\end{array}$} & \multirow{2}{*}{$\begin{array}{c}\begin{array}{c}\text { Fallow } \\
\text { deer }\end{array} \\
\text { - }\end{array}$} & \multirow{2}{*}{$\begin{array}{r}\begin{array}{c}\text { Roe } \\
\text { deer }\end{array} \\
2\end{array}$} & \multirow{2}{*}{$\begin{array}{c}\text { Wild } \\
\text { boar }\end{array}$} & \multirow{2}{*}{$\begin{array}{r}\text { Total } \\
\\
57\end{array}$} \\
\hline & Hunted & $N$ & & & & & & & \\
\hline \multirow[t]{3}{*}{1860} & Hunted & $N$ & 117 & 3 & 0 & $14^{\mathrm{a}}$ & 36 & 23 & 179 \\
\hline & & $\%$ & 65 & 2 & 0 & - & 20 & 13 & 100 \\
\hline & Population size & & 1575 & $?$ & 0 & - & $?$ & $?$ & $?$ \\
\hline \multirow[t]{4}{*}{1894} & Hunted & $N$ & 7 & 20 & 1 & 0 & 15 & 33 & 76 \\
\hline & & $\%$ & 9 & 26 & 1 & 0 & 20 & 44 & 100 \\
\hline & Population size & & 496 & 404 & 373 & 32 & 835 & $900^{\mathrm{lt}}$ & 3040 \\
\hline & & $\%$ & 16 & 13 & 12 & 1 & 28 & 30 & 100 \\
\hline \multirow[t]{4}{*}{1897} & Hunted & $N$ & 37 & 36 & 25 & 3 & 69 & 16 & 186 \\
\hline & & $\%$ & 20 & 19 & 13 & 2 & 37 & 9 & 100 \\
\hline & Population size & & 637 & 545 & 849 & 189 & 1690 & 1100 & 5010 \\
\hline & & $\%$ & 12 & 11 & 17 & 4 & 34 & 22 & 100 \\
\hline \multirow[t]{4}{*}{1900} & Hunted & $N$ & 40 & 36 & 53 & 26 & 325 & 138 & 618 \\
\hline & & $\%$ & 6 & 6 & 9 & 4 & 53 & 22 & 100 \\
\hline & Population size & & 727 & 700 & 2100 & 600 & 4500 & 1500 & 10127 \\
\hline & & $\%$ & 7 & 7 & 21 & 6 & 44 & 15 & 100 \\
\hline \multirow[t]{4}{*}{1902} & Hunted & $N$ & 1 & 3 & 42 & 14 & 51 & 37 & 148 \\
\hline & & $\%$ & 1 & 3 & 28 & 10 & 34 & 25 & 100 \\
\hline & Population size & & 665 & 450 & 2500 & 700 & 5000 & 1800 & 11115 \\
\hline & & $\%$ & 6 & 4 & 23 & 6 & 45 & 16 & 100 \\
\hline \multicolumn{10}{|c|}{ Percentage of hunted } \\
\hline & ungulates (mear & SD) & $9 \pm 8$ & $13 \pm 11$ & $13 \pm 11$ & $4 \pm 4$ & $36 \pm 13$ & $25 \pm 14$ & - \\
\hline \multicolumn{10}{|c|}{ Percentage share in ungulate } \\
\hline & community tme: & SD) & $10 \pm 5$ & $9 \pm 4$ & $18 \pm 5$ & $4 \pm 2$ & $38 \pm 8$ & $21 \pm 7$ & - \\
\hline
\end{tabular}

their guests, and poachers. During the following few decades (especially after another insurgence in 1863-1864), most of the former wardens were gradually transformed into villeins (Karcov 1903). With insuffieient land to live from farming alone, and with gradual annulment of their ancient rights to forest resources, the former guards of BPF often became desperate poachers (Genko 1902-1903). After 1860 , in consequence of the first hunt by the Russian tsar Alexander II in BPF, the whole Forest becane a tsar's hunting ground with very restricted timher exploitation, but with an intense modern hunting management based on German models (Karcov 1903). The main rules of this management were: extermination of predators (large, medium-sized and small species of predatory mammals and birds of prey), promotion of ungulates, reintroduction of red deer, introduction of fallow deer Dama dama, and provision of winter fodder for all species of ungulates. Over 50 years of such management, together with large scale pasturing of cattle in BPF (see below), changed the character of the Forest so much, that German occupants during World War I described BPF as 'Kulturwald', a caltural forest, rather than 'Urwald', a primeval forest (Voit 1917). 
In the 20th century, the Forest experienced the heaviest timber exploitation in its history. In 1915, the tsar's court evacuated east before the invasion of the German army. The following 4 years witnessed the unprecedented slaughter of game by German and Russian soldiers and the local people. In 1919, W. Szafer visiting Bialowieża wrote: "The Forest is as if deserted. In the whole Bialowieza Primeval Forest, I am told, live few dozen red deer, fallow deer and roe deer, and quite many wild boar". The last free-living bison was shot by a poacher in 1919 (Pucek 1991a, b). Also, elk were exterminated. From 1929 till 1939, the Bialowieża Forest was a place of magnificent hunts organised by the Polish president for foreign diplomats. Therefore, red and roe deer and wild boar enjoyed partial protection and steadily increased in numbers. European bison, by a prestigious national project, became restituted from captive-bred animals and reintroduced to the Forest in 1929. The bison lived and were bred in the forest enclosure until the early 1950s, when first individuals were released to the wild (Krasinski 1967, 1993, Pucek 1991a, b). During World War II, BPF was under the Soviet rule (1939-1941), and then following, it was a Reichjagdgebiet of the Nazi occupants (1941-1944). Since 1945, despite different game management practices in the Polish and the Belarussian parts of BPF, numbers of ungulates steadily grew in both parts. In the exploited forests of the Polish part, red deer, roe deer, wild boar, and elk were subject to hunting according to the annual harvest plans (Miłkowski 1970, 1982). Bison, as a protected species, has been a subject of annual culling by the staff of BNP. In the Belarussian part, game was officialiy protected but in the $1950 \mathrm{~s}-1970 \mathrm{~s}$, a harvest by the officials of the communistic authorities took place. In recent decades, culling and relatively small hunting harvests (less than that in the Polish part) of all species of ungulates have been done every year.

The privilege to pasture livestock in the Crown Forest was one of the most ancient rights of people inhabiting BPF and serving as game and forest wardens since the 15 th century. As time past, more and more people from outside BPF got the right for such utilisation of forest resources (Hedemann 1939), However, for few centuries, the pastoral use of the forest was restricted to meadows along rivers and forest outskirsts. In 1506, one of the royal documents confirmed the old rights of the forest and game wardens to "feed and keep their cattle on scythed meadows in winter" (Hedemann 1939). The increasing numbers of settlements around BPF and on glades in its interior caused - inevitably - the increase of domestic ungulate numbers and their spread into the woods. By 1700 , the forest authorities, fully understanding the destructive effect of pasturing in woodlands, did not allow "to drive livestock further than a quarter of a mile $\mid 1$ mile $=7.15 \mathrm{~km}$ ] into forest interior" (Hedemann 1939). In 1781, annual payments made by livestock owners to the Treasury were: 15 grosz for a horse, 6 grosz for a goat, and 3 grosz for either swine or sheep (Hedemann 1939). No cattle were mentioned perhaps because it was less common than the above listed species. In 1795 , when BPF passed under the Russian rule, a law forbidding pasturing in the Forest was issued. Jarocki (1830) found that law sti.l more or less obeyed, and noticed that inhabitants of BPF kept their animals on fenced pastures near their settlements. Nonetheless, local people obviously still utilised the open meadows along rivers. A complaint written in 1829 to the Ministry of Treasure said that wolves killed 18 horses, 30 oxen, 101 cows, 70 calves, 128 swine, 344 sheep and 121 geese (Karcov 1903). While sheep are still the most numerous domestic ungulates, goats disappeared and cattle began to play a more important role.

Probably after 1840 , pasturing of livestock in the woods became common. With a quickly growing human population in the second half of the 19th century, by 1875 livestock grazing was such a threat to the survival of bison, that authorities of $\mathrm{BPF}$ decided upon construction of woden fences separating the bison's part of the forest from that used by cattle (Genko 1902-1903, Karcor 1903). At that time. goats were not mentioned in official documents and sheep were listed as uncommon. Sheep and swine were allowed free access to the woods; the owners were charged for cattle oaly. Horses were not pastured in the woods but in the open meadows along rivers. In the following decades, the wooden fence was not mended and its remains were to remind the local people of the demarcation line between the 'wild' and 'utilised' parts of the forest. However, that line was often trespassed (Karcov 1903). Official statisties reported 6000-8300 cattle pastured in BPF in 1886-1949 (Genko 1902-1903, Karcov 1903, Wróblewski 1927). However, Karcov (1903) believed that the real numbers were still 
higher because the cowherds often cheated and paid charges for fewer cattle than they actually pastured. At its worst. pasturing officially occupied $475 \mathrm{~km}^{2}$ of BPF, that is $38 \%$ of its area. Moreover, since the early 19th century, large herds of livestock were annually driven through BPF. Jarocki (1830) reported herds of oxen driven by merchants from Russia. In the late 19th and early 20th centuries, every year about $3000-4000$ cattle and up to 1000 sheep were driven through BPF, the shortest way to livestock markets in the towns of Bielsk. Brześc, Bialystok, Goniądz, and Narew (Wróblewski 1927).

Although no written documents are available, it is certain that pasturing declined substantially for few years during WW I (1915-1918), when many inhabitants temporarily evacuated east with their livestock and belongings, and during WW 11 (1941-1944) in consequence of fussilades and burning of villages by Nazis. After WW II, the number of cattle depastured in BPF markedly declined. Changes in land ownerships and husbandry pattern in the Soviet part of BPF after 1945, nationalisation of many formerly private meadows along rivers in the Polish part, and decline in human population in the villages around and within the Forest were conducive to the abandonment of that ancient mode of animal husbandry. In the exploited forests of the Polish part, pasturing of cattle was eventually forbidden as late as 1973 by the decision of the State Forestry. At that time, about 1000-1500 cattle grazed in the Polish part of BPF. In the Belarussian part, in the early 1990s, about 600 cattle were still allowed on an area of $69 \mathrm{~km}^{2}$, mainly in the open meadows in river valleys. Therefore, in the 1980s and 1990s, BPF has been relieved from the impact of domestic ungulates for the first time since the turn of the 18 th and 19 th centuries. In this paper, data on cattle pasturing are given only as a background information for presenting the community of wild ungulates. Quantitative data on cattle numbers are anyway too scarce to include them into numerical analysis of the wild ungulate population. The problem of the impact of cattle and wild ungulates on the forest regeneration and functioning will be subject of a separate analysis.

\section{Material and methods}

\section{Methods of inventories of ungulates in BPF}

Inventories of ungulates in BPF (detailed data presented in Appendices I-VII) have over a 200-year tradition; they evolved from the ancient practices of watching game. Since the 16th century, the basic duty of over 200 game wardens was to "keep watch on the beast year round and particularly during the rut season" (from documents cited in Hedemann 1939). In practice, the wardens were expected to possess and perfect the knowledge on where and in what numbers the game could be found when the king or other authorized person arrived for a hunt. Such knowledge was acquired by frequently visiting the respective fragments of the Forest, making tours of inspection on all roads and paths and counting tracks after new snow falls. Because wardens' posts were hereditary, a very intimate knowledge about the beasts was passed through generations. From I798 comes the first information that this duty had heen a regular formal inventory (called "revision of game") done on the same day or few days after the new snow fall by the whole personnel of BPF. The written reports were filed at the office of BPF administration (Hedemann 1935, Hartman 1939). These documents did not persist until now, except for two pieces of correspondence that mentioned the censuses of bison and elk (Hartman 1939).

After several years of breakdown in the administrative protection system of BPF in consequence of the third partition of Poland, counts of bison were resumed under the Russian rule in 1809 . Those of other ungulates were begun in 1890 (Karcov 1903). A detailed description of the technique of bison counting was first given by Jarocki (1830). It was based on a combination of two methods: (1) year-round observations of the herds of bison by each warden in bis district, and (2) snowtracking on a new snow fall. "As soon as the first snow falls, stand out all shooters under the wardens' eyes $[$... and each shooter counts bison's tracks in his district $|\ldots|$ and quietly follows the tracks until he 
catches sight of the animals or becomes convinced that they had not left his district" (Jarocki 1830). On the basis of several individual reports, the chief warden elaborated the final report for the whole area of $\mathrm{BPF}$. In the 18 th and the early 19 th centuries, the counts were based on surveying a fairly reguiar grid of forest roads and paths that marked the division of BPF into 12 units ('straze'), each composed of several smaller (about $10 \mathrm{~km}^{2}$ ) districts ('obchody' or 'obręby'). Totally, 130 people from the forest personnel surveyed the area of about $1000 \mathrm{~km}^{2}$ (Jarocki 1830). Five decades later, Gloger (1881) reported the same method of counting bison and gave even such technical details as that the shooters went with two wooden sticks; on the longer one they notched the number of bison which had gone out of their district, and on the shorter one those which had come into it. "This way" ascertained Gloger, "the count is crosschecked, for each bison notched as a runaway by one shooter must be notched as an arrival in a neighbour's district". Stil!, the acquaintance of each shooter or warden with year round inhabitation of his district by game played an important role in veryfying the results of the snowtracking count.

In the mid 19th century, BPF was divided into forest compartments (first, rectangles $1066 \times 2132 \mathrm{~m}$ and then quadrats $1066 \times 1066 \mathrm{~m}$ ) separated by narrow lines cut in S-N and W-E directions. These lines, in addition to the forest roads and paths, were then used during snowtracking censuses. The grid of snowtracking transects became denser. Alt lines were supposed to be surveyed and most of them were. The number of employed forest and game personnel was about 200 people (Karcov 1903). The whole area of BPF (about $1250 \mathrm{~km}^{2}$ ) was covered in 1-3 days. The total number of animals was a sum of individual reports brought by trackers. For a few days before snowtracking, all feeding racks in the Forest were left empty to make unguhates move around and leave tracks. In 1890, in addition to the usual censuses of bison, all other wild ungulate species were surveyed. However, the first years of censuses yielded unreliable data because the method applied, suitable for animal as large as bison, strongly underestimated the numbers of small species, especially the roe deer. With the construction of about 180 feeding racks (on average, one rack per $7 \mathrm{~km}^{2}$ ) where hay, beetroots, and dried clover were provided in winter, the observations of game at these racks by game wardens had developed into a serious auxiliary method of counting ungulates. This method of visual observations was first. attempted in 1894. Thus, after 1895-1896, when both snowtracking and counts at feeding racks were fully worked out and conducted, the surveys of deer and wild boar yielded more reliable numbers (Karcov 1903). No information is available on how the ungulates were censused in 1925-1940, but most likely the snowtracking method was practiced (Milkowski 1969).

After WW II, snowtracking on the grid of forest compartment lines $(1066 \times 1066 \mathrm{~m}$ ) was done annually (by about 100 people in each census) in the Belarussian part of BPF by the Game Management and Hunting Department staff of Belovezskaya Pushcha. Similarly, snowtracking was the basic survey method applied in the exploited forests of the Polish part and in BNP. In this method, all ungulate tracks were counted and their direction marked on a map. The difference between entering and leaving tracks gave the number of animals present in a given compartment. This method was tested in the Belarussian part in 1949 by Sablina (1955), and in the exploited forests of the Polish part in 1969-1973 by Pucek et al. (1975). In all cases, the results of snowtracking, as compared to drive censuses (so far the most accurate method of survey) in the same plots, appeared to be underestimated (details in Appendices II-V). Sablina (1955) has also compared the results of snowtracking censuses conducted on grids $1066 \times 1066 \mathrm{~m}$ and $533 \times 533 \mathrm{~m}$. The latter grid size yielded numbers of ungulates close lo absolute ones because the proportion of undetected anjmals (je those that stayed inside the quadrats) was very smali.

In the Belarussian part of BPF, the snowtracking method was modified. It was still conducted on a grid $1066 \times 1066 \mathrm{~m}$, but twice during each winter, usually on two consecutive days or at few days' interval, and the tracks counted on the first day were obliterated. Double count increased the detectability of animals. Moreover, correction coefficients (a ratio of drive census to snowtracking results) worked out by Sablina (1955) were considered in final reports on game numbers.

In the exploited forests of the Polish part of BPF. data on game numbers (red and roe deer, moose, wild hoar 1 are available from 1946, 1950, and 1958-1993. Snowtracking was the most common 
method, but it was not applied every year. During the winters poor in snow, numbers of ungulates were assessed based on the latest censuses fron the previous year, known hunting harvest. year-round observations by game wardens, and counts of wild boar at several baiting sites. Obviously, such assessments were rather arbitrary and suffered from errors of underestinate, too. In the Polish part of BPF, drive censuses were done by the staff of Game Management of the Forestry Administration on six years in the exploited forests $(1969,1971,1973,1991,1992,1993)$ and by the staff of the Mammal Research Institute and Białowieza National Park on two years in BNP (1991 and 1992) (Pucek et al. 1975, Jędrzejewska et al. 1994). In the exploited forests, drive censuses covered from 29 to $55 \mathrm{~km}^{2}(5-13 \%$ of the total area). Forest compartments to be surveyed were randornly selected. In BNP. these censuses were conducted on $11.2 \mathrm{~km}^{2}$ ( $24 \%$ of the BNP area). During a drive census, each forest compartment or block of adjoining compartments to be censused was surrounded by observers, who stationed themselves at intervals of $50-100 \mathrm{~m}$ (to keep visual contact). The observers along three sides of a censused compartment or block of compartments remained stationary, while those along the fourth side noved inward and went through the entire area. Each observer kept visual contact with the nearest neighbour while moving in an extended line (battue line). The observers (both stationary and moving ones) noted the ungulates passing through a line of observers (on their right hand side only) and going out of or in to the closed area being censused. The drive censuses yielded the numbers of ungulates close to real ones, and served us as reference points for verifying al: other estimates. Mean ratio of drive census to snowtracking results was applied as correction coefficient to the numbers of ungulates obtained by snowtracking (Appendices II-V). Bison population was censused annually by counts at winter feeding sites and snowtracking conducted by the staff of Bialowieża National Park. Additionally, we used data on the snowtracking of ungulates in BNP conducted in 1957-1962 (courtesy of A. Kawecki), 1987 (Jędrzejewski et al. 1992) and in 1992 (courtesy of BNP headquarters). Ungulates were surveyed on the grid of transects covering $47.5 \mathrm{~km}^{2}$ (entire $\mathrm{BNP}$ in 1957-1962 and 1992, and on $11.2 \mathrm{~km}^{2}$ (SW part of BNP) in 1987. In cases, when no data were available (in 1947-1949,1951-1957 in the exploited forests of the Polish part and in most years in BNP), numbers of ungulates were reconstructed based on highly significant correlations between the censused numbers in the Polish and Belarussian parts of BPF (details in Appendices III-V). Other sources of information on ungulates (hunting statistics, mortality data, etc) were used as auxiliary data to assess the reliability of various indices of ungulate abundance. Full sets of data, detailes of methods of calculating densities, and the analysis of reliability of data are given in Appendices I-VIl, separately for each species of ungulate.

\section{Human impact on ungulates}

Direct impact of humans on ungulates included legal hunting harvest, poaching by local people. and slaughters executed during the warfare times by both foreigners and local people. Quantitative data on all types of exploitation of ungulates are scanty and only rarely were the numbers reliable, eg results of monarchial hunts in $1752-1903$ and hunting quotas in the Polish part of BPF in 1960-1993. Indices of poaching intensity (annual numbers of carcasses found in snares by game wardens) were available from the Polish part in 1984-1994 (Okarma et al. 1995). In addition, numerous descriptive evaluations of all types of human exploitation of game were found in written documents and reports. From all these quantitative and qualitative data a clear picture emerged: since wild ungulates have always been a source of 'free' food to people, human impact on their populations grew with worsening of political and economic instability in the region. Hence, to indirectly assess the human disturbance to ungulate community, we ranked the political and economic stability in each year (1795-1993) according to an arbitrary scale from 5 (peace and prosperity) to I (world wars).

\section{Numbers of wolves and lynxes}

Historical account of wolf and lynx management, control, and protection, the demography of these predators, and full data on their densities are presented by Jegdrzejewska ef al (1996) and 
Jędrzejewski et al. (1996). Quantitative data on wolf numbers in BPF cover years 1847-1993. For 1847-1915, estimates of wolf population size were reconstructed based on numbers of wolves killed For 1928-1993, results of winter censuses (by snowtracking) were given. Estimates of lynx population density are available for the period of 1869-1993, first (before 1915) as reconstructions based on intense hunting harvest, and later (after 1928) as results of winter censuses.

\section{Weather variables}

A meteorological station has been operated in Biatowieża since 1948. From its records we obtained data on temperature and snow cover. Mean daily snow cover was calculated for the period of 1 November - 30 March. Long-term (1780-1980) records of temperature from Vilnius and Warsaw (published by Paczos 1993) made it possible for us to reconstruct the temperature in Białowieża in 1780-1947. Vilnius (Lithuania) is located $247 \mathrm{~km} \mathrm{NNE}$, and Warsaw (Poland $200 \mathrm{~km}$ SWW of Białowieża village. A series of 33 years (1948-1980) covered by temperature measurements from all three localities was used for correlations in pairs Białowieża-Vilnius and Biatowieża-Warsaw. Both pairs showed very high correlation coefficients, but better fit was obtained in Biafowieza-Vilnius series (mean temperature of January; $r=0.96, p<0.0005, n=33$ years; mean temperature of July: $r=0.86, p<0.0005$; mean annual temperature: $r=0.88, p<0.0005$ ). Based on regression equations and known temperature from Vilnius, we reconstructed the temperature of Bialowieza in 1780-1947.

\section{Indices of food abundance to ungulates}

Data on oak seed crops in 1958-1993 (listed in Appendix V) were provided by the Bialowieza Forest Administration. The indices of crops (in kilograms) were the annual purchases (for replantation purposes) of acorns from the local people, who gathered them in Białowieza Forest District (exploited forests of the Polish part of BPF). The amount of acorns gathered by people depended primarily on seed crop, but it might also have been influenced by current prices. We think that the latter factor caused serious underestimate of crop in 1989 only, when low prices (due to inflation) discouraged the collectors. Based on our own observations, we assessed the 1989 crop as superabundant.

\section{Statistical analysis}

To investigate the roles of density-independent variables in population dynamics of wild ungulates, we plotted ungulate densities and annual increase rates against various extrinsic (environmental and human-related) factors. By annual increase rate of population we meant a difference in population numbers in year $n$ and $n+1$, expressed as percentage of numbers in year $n$. Besides using annual records of each parameter, we smoothed some variables by calculating moving averages (Chatfield 1989). This procedure was applied to population sizes and increase rates of bison, elk, red deer, roe deer, and wild boar to reduce the possible effect of sampling error (3-year moving averages). When testing the impact of temperature on ungulates, we computed 5-year moving average of the mean annual temperature (including years $n-4, \ldots, n$ ), because annual temperature was used both as a direct measure of climatic trends and as an indirect index of food availability and supply for ungulates. To test for the existence of density-dependence in the variation of population sizes of the wild ungulates, we applied the randomization test of Pollard et al. (1987). The procedure is based on comparing some statistics calculated for the observed series of data with those obtained for a large enough number of random permutations of the data (we did 1000 permutations).

Finally, to assess the roles of density-dependent and density-independent factors in population dynamics of Bialowieża's ungulates, we conducted multjple regression analysis with (1) population density and (2) population increase rate as dependent variables, and various environmental and intrinsic factors as independent variables. Furthermore, for each factor that contributed to the total variation explained, semipartial correlation squared was calculated. This measure expresses the unique contribution of a given factor (independent variable) as a proportion of the total variance explained of a dependent variable (Tabachnick and Fidell 1983). We are aware of the fact that the applied methods of analysis can only show correlations and not cause-and-effect relationships. When 
attributing causality to any of the revealed correlations, we proceed from facts to interpretation; this is done in Discussion.

\section{Results}

\section{Climatic conditions of Bialowieza Forest in the 19th and 20th centuries}

Between 1780 and 1995 , the mean annual temperature in $\mathrm{BPF}$ averaged $7.0^{\circ} \mathrm{C}$ (range $5.1-9.2^{\circ} \mathrm{C}, n=215$ years; Fig. 2). The 10-year moving average showed that years $1780-1820$ and $1920-1970$ were markedly cooler than the long-term mean conditions. Warmer than average were the 50-year period between $1820-1870$ and the recent 25 years (1970-1995). In 1870-1920, annual temperature oscillated around the long-term average level (Fig. 2). In the whole 215-year series, no consistent trend of either increase or decrease of the mean annual temperature was detected. Mean temperature of July varied from 15.2 to $22.5^{\circ} \mathrm{C}$ (on average $18.4^{\circ} \mathrm{C}$ ) and it showed a slight (not significant) trend of decline (by $0.3^{\circ} \mathrm{C}$ per 100 years). More variable was the mean temperature of January: it ranged from -16.8 to $1.8^{\circ} \mathrm{C}$ (mean $-4.8^{\circ} \mathrm{C}$ ) and showed a trend of increase at a mean rate of $0.6^{\circ} \mathrm{C}$ per 100 years. In consequence, during the 19 th and 20 th centuries, the climate of Bialowieza was characterised by decreasing amplitude between July and January mean temperatures $\left(Y=39.711-0.009 X, n=215, R^{2}=0.15, p=0.03\right)$; winters became milder and summers slightly cooler. It means a trend of change from a continental-type to an Atlantic-type climate. In the cold seasons (1 Nov - 31 Mar) of 1948/49-1995/96, the mean daily snow cover varied from 1 to $42.5 \mathrm{~cm}$ (mean $10 \mathrm{~cm}$ ) (Fig. 3). Correlation between mean temperature of January and snow cover

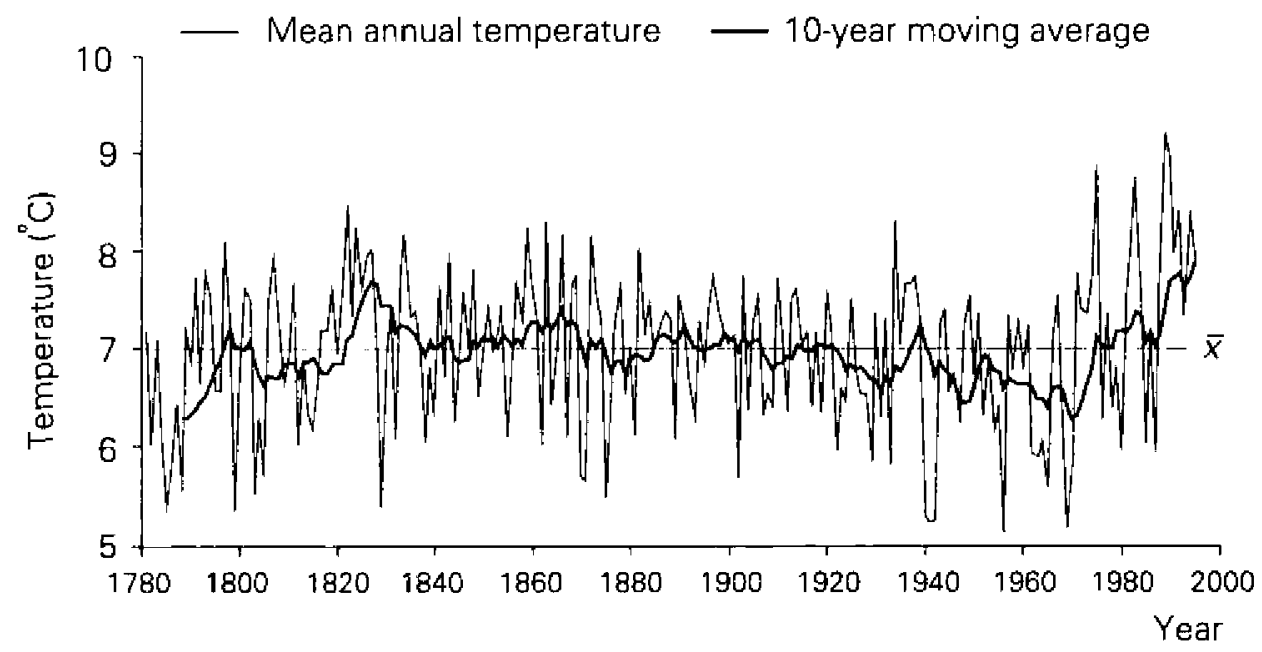

Fig. 2. Mean annual temperature of Bialowieża in 1780-1995. Records from 1948-1995 come from Bialowieża meteorological station. Data from 1780-1947 are reconstructed based on temperature records in Vilnius. Ten-year moving average gives, for each year, a value averaged for a given year and nine preceding years. 


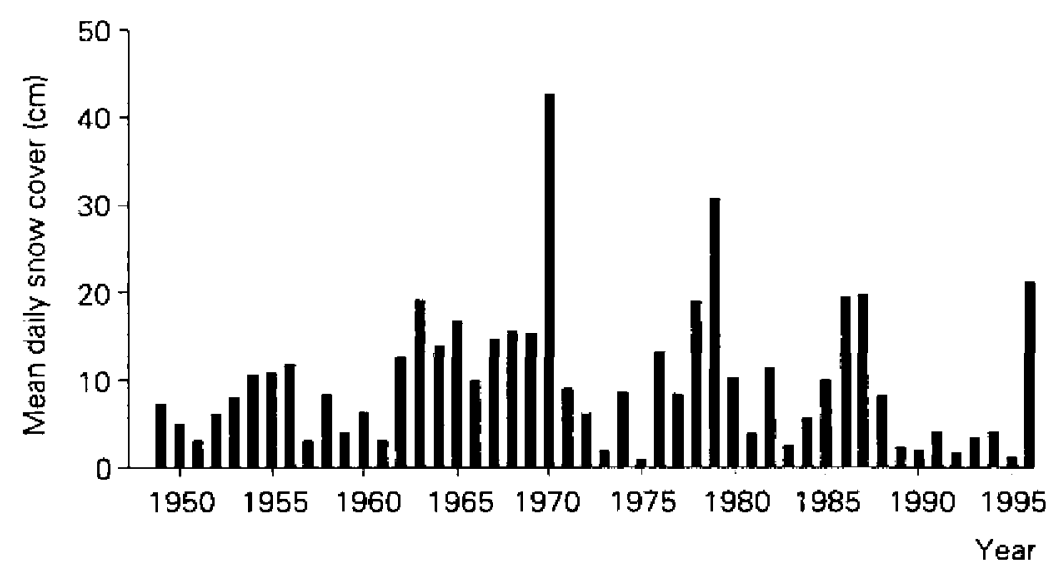

Fig. 3. Mean daily snow cover in the cold seasons (1 November - 31 March) of 1948/49-1995/96 in Bialowieża.

in the cold season, although highly significant, was not strong $(r=0.50, p<0.0005$, $n=47$ years).

\section{Estimated numbers and population dynamics of ungulates}

How many bison lived in BPF before 1800 can only be assessed indirectly. In 1860-1902, the number of bison killed during monarchial hunts and the estimated population size were significantly correlated $(Y=463.508+8.824 X, n=5, r=0.95$, $p=0.014$ ) (Table 1). From the regression equation, we estimated that in 1752 (when 42 bison were killed during a hunt), population of bison could have been about 830 head. A similar figure ( 700 head), probably based on inventories that did not persist until present, was given by Brincken (1828) for the end of the 18th century. If so, there were about 0.7 bison $/ \mathrm{km}^{2}$ (at that time BPF covered ca $1000 \mathrm{~km}^{2}$ ). Also, the detailed description of BPF from 1796 ("Opisanie puszcz ekonomii brzeskiej..." by J. Szczepanowski, cited after Hedemann 1939) reported that bison inhabited 11 out of 13 forest administration units (it was not reported from Dziadówka and Podbiala units, SE region of BPF); ie about $80 \%$ of the Forest's area. It indicates that bison must have been numerous at that time, because the area utilised by bison is known to increase with growing population numbers (Krasiński et al. 1994).

In 1798-1807, when BPF passed under the Russian rule and its north-west border became the border of Russian and Prussian occupation zones, bison were intensively poached by local people and intruders from beyond the Prussian border. Protection and supplementary winter feeding ceased, and the numbers of bison dropped to slightly above 200 in 1802 (Hartman 1939). Later, when protection resumed, the bison began to grow in numbers (Fig. 4), until they reached high population of 1898 head (density $1.5 \mathrm{inds} / \mathrm{km}^{2}$ ) in 1858 . Although this figure may 

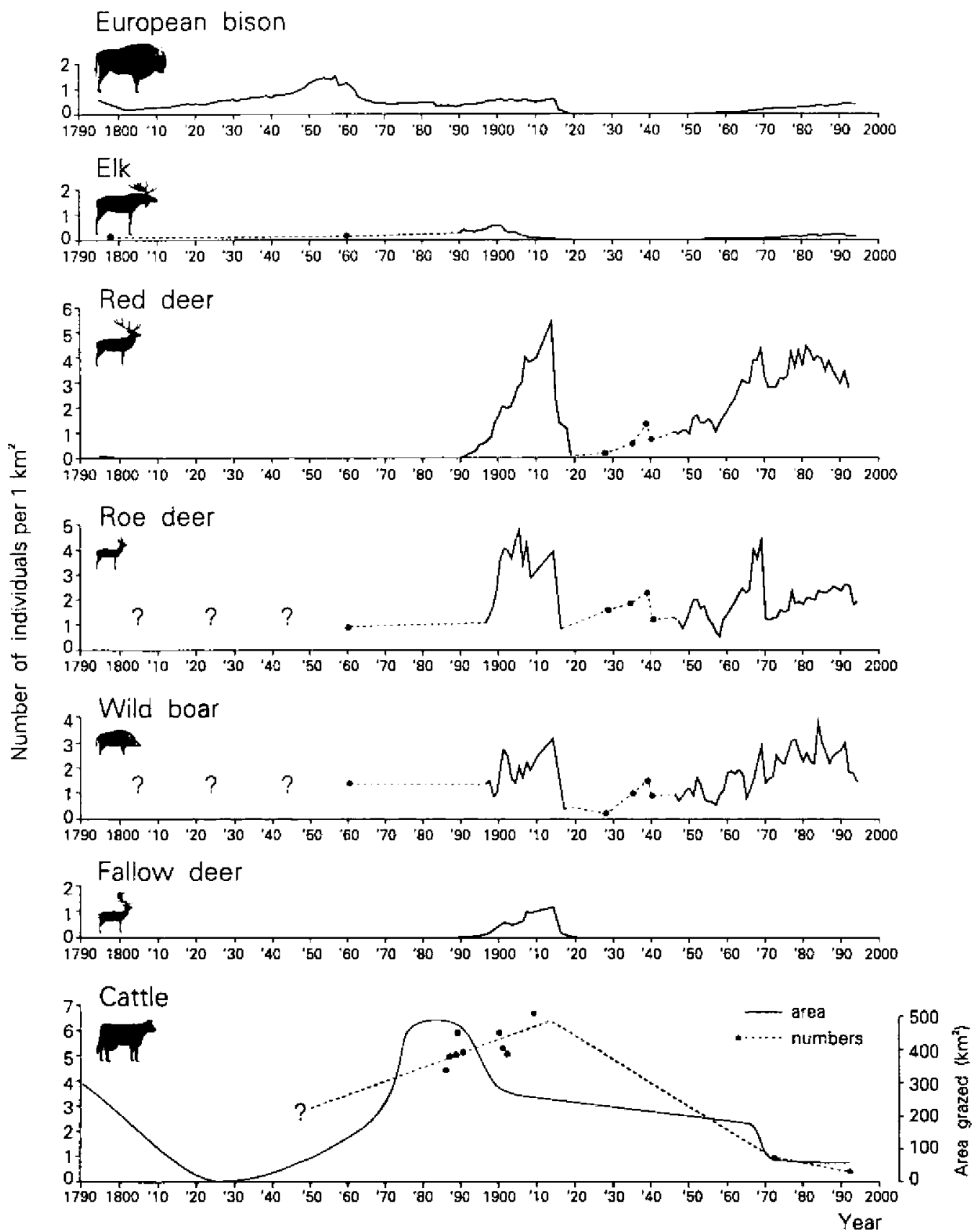

Fig. 4. Multi-annual variation in densities of wild and domestic ungulates and area grazed by cattle in BPF in 1798-1993. Methods of censuses and reconstructions in Appendices I-VII. Solid lines and points - data based on censuses, dashed lines - interpolations. 
be an overestimate (see Pucek 1991a), undoubtedly, the bison population was dense at that time. Decline in bison numbers began in 1861. It was deepened during the Polish national insurgence in 1863-1864, and continued afterwards as well. During 10 years (1857-1868), the numbers of bison declined over 3-fold. Data on bison mortality gathered by the forest administration and cited in full by Karcov (1903) do not indicate any epizooty or other obvious reasons for increased mortality. The irreversible decline in bison population coincided with a rapid increase in numbers of cattle at that time. The lowest numbers of bison ( 380 head in 1889 , ie $0.3 \mathrm{inds} / \mathrm{km}^{2}$ ) were reported when the area grazed by cattle was largest (Appendix VII). Soon, the restrictions in pasturing were issued and the numbers of bison began to recover. The population stabilised at about 700 individuals (0.5-0.6 inds $/ \mathrm{km}^{2}$ ) in 1900-1915 (Fig. 4). Extermination of bison during World War I took 4 years (1915-1919), and it proved that at any time of political turmoil and poverty, this large slow animal with very low reproductive rate, excellent meat and hide, may be threatened by extinction.

After reintroduction in the early 1950 s, bison population has been growing steadily. From the 1970s, livetrapping (in order to relocate) and culling of bison takes place annually at the average level of $11 \%$ of recorded numbers in the Polish part of BPF, and $2-5 \%$ in the Belarussian part (Krasinski et al. 1994). Natural mortality of bison is very low, about $3 \%$ in both parts of BPF (Krasinski et al. 1994). In the 1990s, numbers of bison (stabilised by annual culling) were 520-590 head (about 0.4 bison $/ \mathrm{km}^{2}$ ) and, for the first time in recent centuries, the bison have been living in the forest nearly free of cattle (Fig. 4).

Elk have usually been the least common ungulate in BPF. The first records of elk killed during the large-scale monarchial hunts are from 1752 and 1860 (Table 1). By comparison to other monarchial hunts in 1894-1902, we estimated that roughly 300 elk $\left(0.3 / \mathrm{km}^{2}\right)$ lived in BPF in 1752 and $170\left(0.1 / \mathrm{km}^{2}\right)$ in 1860 . The count done in 1798 yielded a figure of $125 \mathrm{elk}$, ie $0.1 / \mathrm{km}^{2}$ (Hartman 1939). In 1899 , population reached a maximum of 730 head $\left(0.6 \mathrm{inds} / \mathrm{km}^{2}\right)$ and began to decline (Fig. 4). During WW I, elk were eradicated from BPF. An attempt at reintroduction was undertaken in the late $1930 \mathrm{~s}$, but no captive-bred individuals were released to the wild before 1939 when the project was discontinued (Karpinski 1951). After 1945, elk began to recolonise BPF from north-east. In 1946 it was recorded in the Belarussian part, but only in 1967 did the elk permanently return to the Polish part of BPF. The censuses of elk done separately in each part of BPF after 1945 , showed the increase of numbers (up to 318 individuals, ie $0.2 / \mathrm{km}^{2}$ in 1990). Data collected in the Polish and Belarussian parts in 1967-1980 (ie after elk recolonised both parts but before the border fence divided the population) are significantly correlated ( $r=0.81, n=16$ years, $p=0.0001$ ). In 1992-1993, in the Polish part, elk declined due to deliberately elevated hunting plans (on average $30 \%$ of winter numbers) (Fig. 5).

The native red deer occurred in BPF in the 15th-16th century as can be judged from hunting privileges granted by the kings (Hedemann 1939). Probably during 

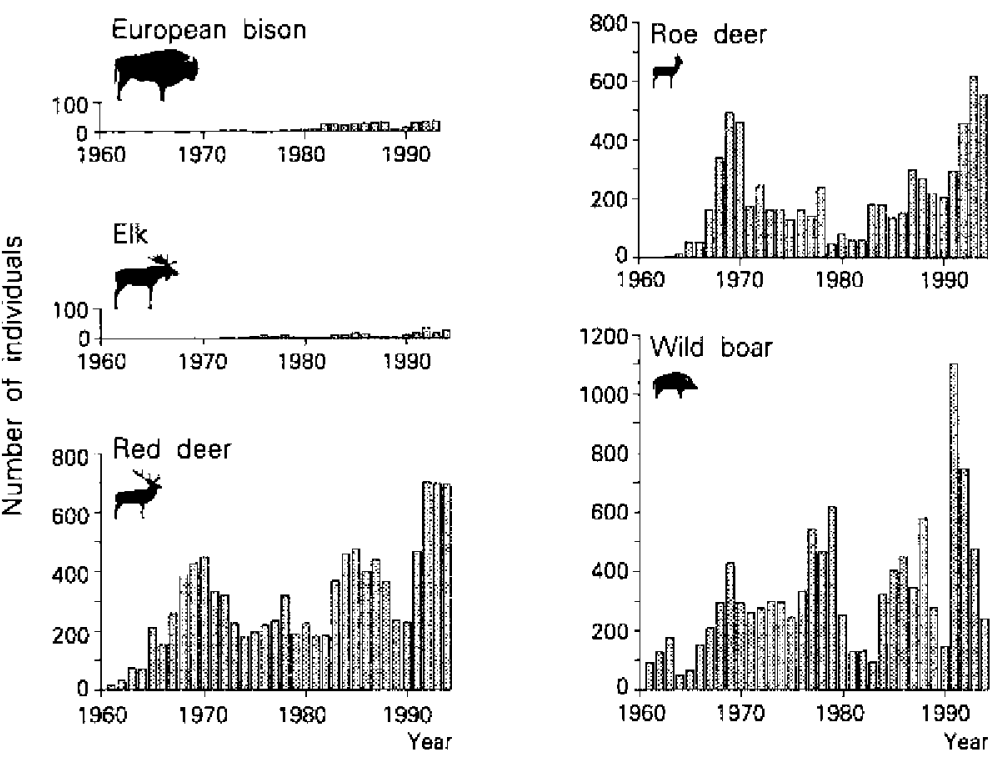

Fig. 5. Annual culling of European bison and hunting harvests of elk, red deer, roe deer, and wild boar in the exploited forests of the Polish part of $\mathrm{BPF}$ in 1960-1994.

the Little Ice Age (17th century), red deer declined. It was not reported as a trophy of the hunt by August III Saxon in 1752 (Table 1). Brincken (1828) wrote that in the mid 18th century, 50-60 red deer inhabited BPF but the series of severe winters (cf Fig. 2) caused their extinction before 1800. Jarocki (1830) found no red deer in BPF, but game wardens told him that red deer antlers were occasionally found in rivers by fishermen. In the second half of the 19th century, the decision to re-establish red deer in the tsar's hunting ground was made and deer brought from Silesia were bred in the large forest enclosure in BPF (Karcov 1903). In 1890, the first individuals were released to the wild. The free-living population, supported by further releases of deer from the enclosure, began to grow exponentially and reached 6800 individuals $\left(5.4 \mathrm{deer} / \mathrm{km}^{2}\right)$ in 1914 (Fig. 4).

After the decimation of the population during WW I, the red deer was saved from heavy hunting pressure in 1920-1960 and slowly recovered. In 1969, population comprised over 6000 head ( $4.3 \mathrm{deer} / \mathrm{km}^{2}$, Fig. 4), which was the highest numbers since 1914. An exceptionally severe winter in 1969/70 reduced the population by $25 \%$. In the exploited forests of the Polish part alone, 809 earcasses of red deer that died from starvation and cold were found by game wardens (Okarma et al. 1995). However, deer recovered by 1977, and since that time their numbers varied from 2.8 to $4.4 \mathrm{inds} / \mathrm{km}^{2}$ (Fig. 4). Since 1991, because of complaints by foresters on damage caused by ungulates (mainly red deer) in forest replantations, the annual hunting harvest in the exploited forests of the Polish part 
increased to about $25 \%$ of the late winter number (Fig. 5). This contributed to stabilisation, indeed a decline of red deer numbers in recent years. The results of deer censuses conducted in 1946-1980 separately in the Polish and Belarussian parts were significantly correlated $(r=0.81, n=24$ years, $p<0.0001)$.

At least over the period recorded, roe deer population have maintained a continuous presence in BPF. During the tsar's hunt in 1860 , 36 roe deer were killed (Table 1), which by comparing to other monarchial hunts, allowed us to estimate the population size as 1200 roe deer (ie about 1 deer $/ \mathrm{km}^{2}$ ). Regular censuses that began at the end of the 19th century, revealed similar densities (1.1 roe deer $/ \mathrm{km}^{2}$ in 1896), which increased rapidly to reach $2.9-4.3 \mathrm{inds} / \mathrm{km}^{2}$ in 1900-1915 (Fig. 4). Roe deer, although hunted intensively during WW I, suffered relatively little compared to other species and began to recover in the between-war period. After WW II numbers of roe deer were extremely variable. They slowly increased in 1946-1954, then began to grow exponentially until 1969, when 4.4 roe deer $/ \mathrm{km}^{2}$ were recorded (ie numbers as high as those in 1900-1915). During that period there was little hunting pressure on roe deer (Fig. 5). An exceptionally severe winter of $1969 / 70$ reduced the numbers of roe deer by $70 \%$. During that winter, game wardens found 1226 carcasses of roe deer that died from starvation and cold in the exploited forests of the Polish part of BPF (Okarma et al. 1995). The results of roe deer counts conducted in the Polish and Belarussian parts in $1969-1980$ were significantly correlated $(r=0.92, n=10$ years, $p=0.0002)$. Since the $1980 \mathrm{~s}$, the roe deer densities oscillated at 2.0 to $2.6 \mathrm{inds} / \mathrm{km}^{2}$. In the early $1990 \mathrm{~s}$, the annual hunting harvest in the exploited forests of the Polish part intensified (to 25\% of winter numbers, on average; Fig. 5) and contributed to the decline of the roe deer.

Wild boar has been a permanent inhabitant of BPF. During the first hunt of the Russian tsar in 1860, 23 wild boar were driven to a large hunting enclosure (Table 1). By comparing that figure to results of other monarchial hunts, we estimated that at least 1000 wild boar $\left(0.8 \mathrm{inds} / \mathrm{km}^{2}\right)$ lived at that time in BPF. Bobrovskii (1863) reported that in 1840 a great number of wild boar died from starvation and cold during periods of severe frosts and deep snow. Lairs with 20-30 dead wild boar were often found in the forest, and their numbers were low after that event. Similar natural reductions of wild boar numbers occurred in 1882 and 1889 (Karcov 1903). Thus, the regular censuses that began at the end of the 19 th century, first reported very low numbers of wild boar $\left(0.8 \mathrm{inds} / \mathrm{km}^{2}\right)$. In $1896-1915$, the population size was highly variable but increasing to 3.15 boar $/ \mathrm{km}^{2}$ in 1914 (Fig. 4). In 1915-1921 wild boar, as all other species of ungulates, were the subject of intense killing (for food) by soldiers and local inhabitants. Scarce data from 1917-1940 indicate low and moderate abundance of wild boar $(0.2-1.5$ boar $/ \mathrm{km}^{2}$ ). The results of censuses conducted separately in the Polish and Belarussian parts after 1945, showed an increase (although with high fluctuations and periodical declines) of wild boar numbers, up to 3.8 inds $/ \mathrm{km}^{2}$ recorded in 1984 (Fig. 4). The data from the two parts of BPF from 1946-1980 were significantly 
correlated ( $r=0.72, n=25$ years, $p<0.0001)$. Hunting harvest of wild boar in the Polish part followed the fluctuations in boar numbers (Fig. 5).

In the late 19th century, fallow deer was introduced to BPF to "enrich" the tsar's hunting preserve. After few years of breeding in a large forest enclosure, dozen individuals were released to the wild in 1890 . Supported by abundant winter feeding and lack of large predators (Jędrzejewska et al. 1996, Jędrzejewski et al. 1996), the fallow deer population grew to nearly 1500 head $\left(1.2 \mathrm{inds} / \mathrm{km}^{2}\right)$ in 1914 (Fig. 4). During WW I, they were eradicated by soldiers and poachers. After 1920 no fallow deer remained in $\mathrm{BPF}$.

In BPF, pasturing of cattle intensified throughout the 19th century (see the earlier section on History of the status and oecurrence of ungulates in BPF). During $1875-1889$, the forest area grazed by cattle $\left(457-475 \mathrm{~km}^{2}\right)$ was larger then ever. Numbers of cattle peaked in 1909 , when 8342 head $\left(6.7 \mathrm{inds} / \mathrm{km}^{2}\right)$ were recorded (Fig. 4). We assumed that the rate of increase in cattle densities, reported by statistics available from $1886-1909\left(Y=-97.619+0.054 X, n=8\right.$ years, $R^{2}=0.45$, $p=0.07$, where $Y$ - density of cattle in $N / \mathrm{km}^{2}, X$ - calendar year), reflected the long-term trend in 1850-1914. In the second half of the 20th century, abundance of cattle pastured in the forest declined steadily, to about $1-2.5 \mathrm{head} / \mathrm{km}^{2}$ in the $1960 \mathrm{~s}$ and $<0.5 \mathrm{head} / \mathrm{km}^{2}$ in the $1990 \mathrm{~s}$ (Fig. 4). More importantly, during the recent decades, pasturing was taking place in riverside meadows and larger glades rather than in the forest proper.

Community of ungulates in Bialowieźa Primeval Forest - changes in time

After the extinction of native red deer by 1800 , the community of ungulates consisted of four species (bison, elk, roe deer, and wild boar) for nearly 100 years. Although very scarce data are available on that period, all sources indicate that roe deer and wild boar were dominating, followed by bison. Elk were the least numerous. We estimated that in $1860-1899$, the abundance of all wild ungulates was fairly low (4-6 inds $/ \mathrm{km}^{2}$ and $510-660 \mathrm{~kg}$ of biomass $/ \mathrm{km}^{2}$ ). In terms of biomass, bison predominated constituting probably over half of total biomass of wild ungulates (Figs 6 and 7). The situation changed soon after 1900, when restitution of red deer and introduction of fallow deer became successful, and numbers of bison and elk declined. Total densities of wild ungulates reached the highest ever recorded level of $14.4 \mathrm{inds} / \mathrm{km}^{2}$ (Fig. 6). Red deer dominated ( $38 \%$ of total numbers), followed by roe deer (28\%) and wild boar (22\%). In 1914, total biomass of wild ungulates reached $1180 \mathrm{~kg} / \mathrm{km}^{2}$ and was dominated by red deer $(46 \%)$, wild boar (21\%), and bison (20\%) (Fig. 7).

Through the second half of the 19th century, the number of cattle grazing in BPF grew steadily. In the first decade of the 20th century, cattle made up 30-40\% of all ungulate numbers, and as much as $60-70 \%$ of biomass (Figs 6 and 7 ). Thus, by 1914, the average square kilometer of the forest sustained (or rather suffered from), on average, 21 ungulates (wild and domestic animals combined) and 3110 $\mathrm{kg}$ of ungulate biomass. Already in the first decade of the 20th century, the 


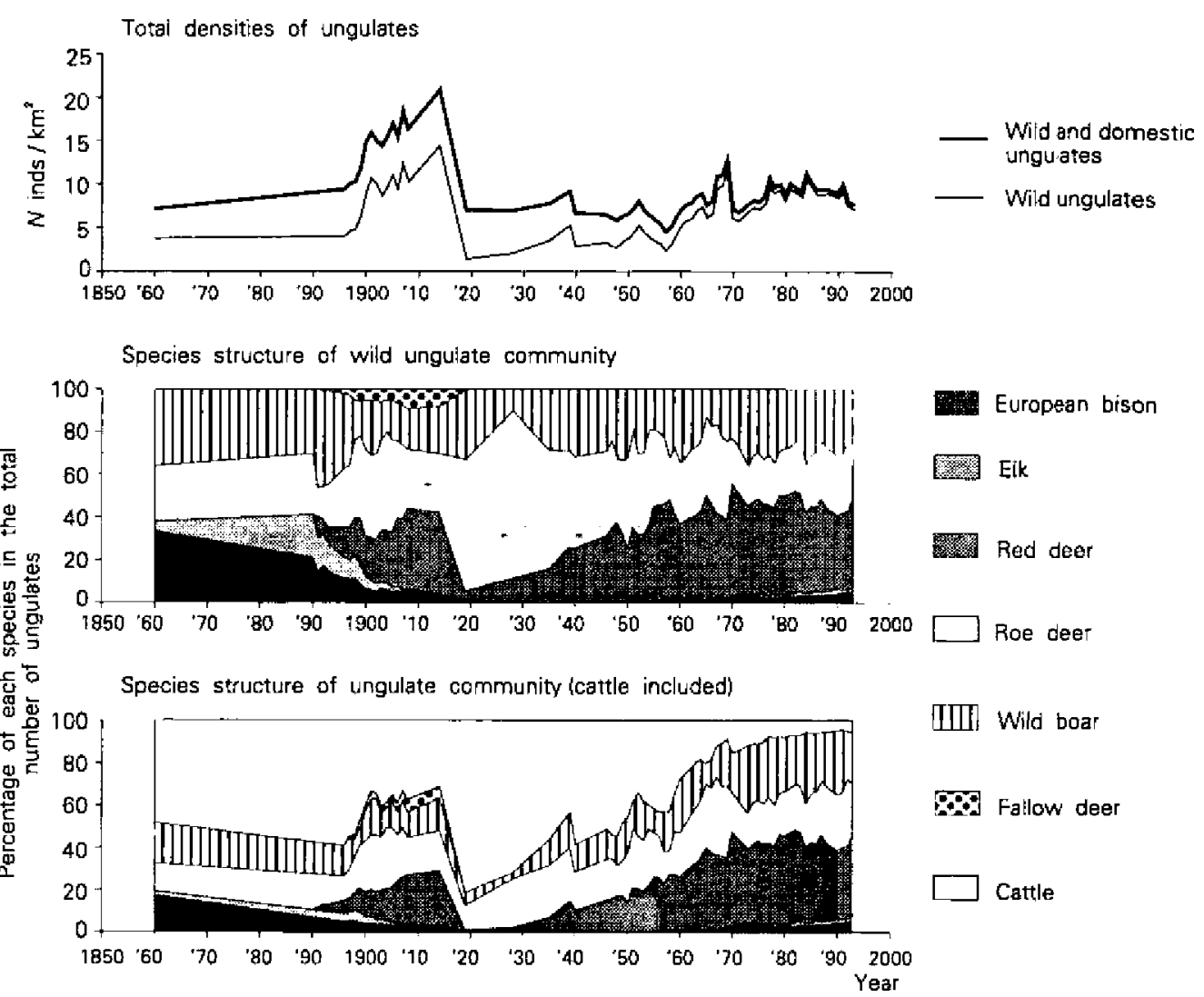

Fig. 6. Upper graph: variation in the total densities of ungulates in BPF in 1860-1993. Data in Appendices I-VII. Two lower graphs: changes in species structure of the ungulate community (with and without cattle). The share of each species shown as percentage in the total numbers of ungulates. Note that two periods (1860-1897 and 1909-1946) are represented by few data joints (see Fig. 2).

symptoms of overcrowding were recorded (poor quality of antlers and low body mass, Karcov 1903; epizooty in 1909, Wróblewski 1927) but it was only the prolonged slaughter by man during WW I that caused a 10 -fold decline in numbers of wild ungulates (18-fold decline in biomass) and extermination of three out of six species between 1914 and 1919 (Figs 4, 6, and 7). In 1919, < 2 wild ungulates $/ \mathrm{km}^{2}$ were recorded (about $65 \mathrm{~kg} / \mathrm{km}^{2}$ ), with $61 \%$ of numbers being roe deer, $32 \%$ wild boar, and $6 \%$ red deer.

For the following 33 years (1920-1952), the community of ungulates consisted of three species only (roe deer, wild boar, red deer), which lived at fairly low densities (up to 5 inds $/ \mathrm{km}^{2}$, and $300-340 \mathrm{~kg}$ of biomass $/ \mathrm{km}^{2}$; Figs 6 and 7 ). The proportion of red deer was rapidly growing at that time. After 1952, restitution of the free-living population of bison and spontaneous recolonisation of BPF by elk enriched the community. The numbers of wild ungulates peaked again in 1969 


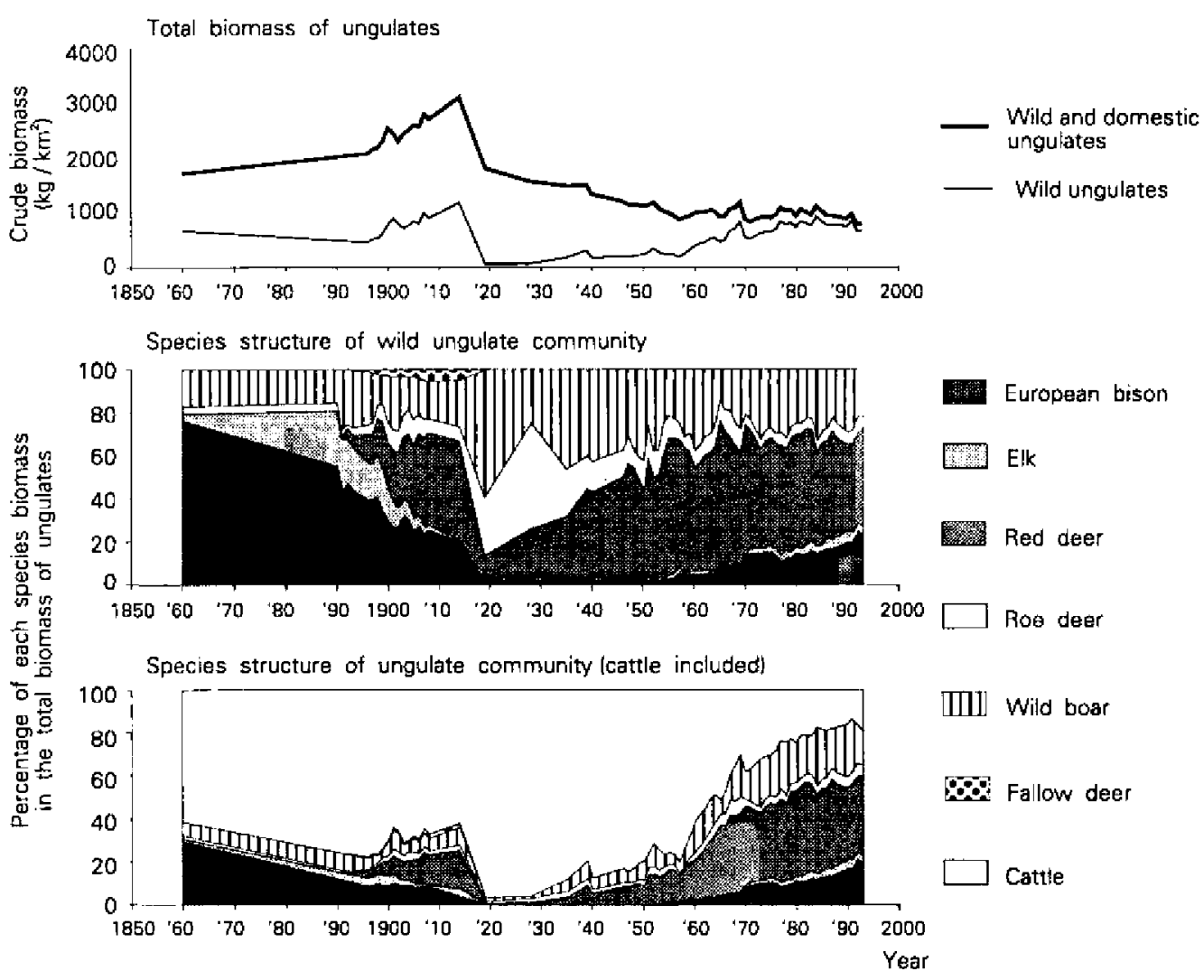

Fig. 7. Upper graph: variation in the total crude biomass (in $\mathrm{kg} / \mathrm{km}^{2}$ ) of ungulates in BPF in 1860-1993. For calculation of biomass, the density of each species $\left(N\right.$ inds $/ \mathrm{km}^{2}$ ) was multiplied by mean body mass: European bison - $400 \mathrm{~kg}$ (Krasińska 1988), elk - $200 \mathrm{~kg}$ (Pucek 1984), red deer $100 \mathrm{~kg}$ (Dzięciolowski 1969), fallow deer - $50 \mathrm{~kg}$ (Pucek 1984), roe deer - $20 \mathrm{~kg}$ (Milkowski 1970, Pielowski 1988), wild boar - $80 \mathrm{~kg}$ (Pucek 1984), cattle - $300 \mathrm{~kg}$ (Skolasiŕski et al. 1966). Two lower graphs: changes in species structure of the ungulate community (with and without livestock). The share of each species biomass shown as percentage in the total biomass of ungulates. Other explanations as in Fig. 6.

(11.7 inds $/ \mathrm{km}^{2}$ ) whereas their biomass was highest in $1984\left(920 \mathrm{~kg} / \mathrm{km}^{2}\right)$. Despite a sharp decline of ungulates in the extremely severe winter of $1969 / 70$, the entire community entered the most stable period in its bicentennial history. In 1975-1993, numbers (from 7.1 to $10.7 \mathrm{inds} / \mathrm{km}^{2}$ ) and biomass (from 650 to 920 $\left.\mathrm{kg} / \mathrm{km}^{2}\right)$ were fairly high. The community was dominated by red deer $(34-52 \%$ of numbers, $41-56 \%$ of biomass), followed by wild boar (18-35\% of numbers, $15-32 \%$ of biomass), and roe deer (21-33\% of numbers, $5-8 \%$ of biomass). Bison was uncommon ( $2-5 \%$ by numbers) but it formed $10-25 \%$ of total biomass of wild ungulates in 1975-1993. In the early 1990s, livestock pastured in BPF (almost all 
in the Belarussian part) made only $5 \%$ by numbers and $10 \%$ by biomass of all ungulates (Figs 6 and 7).

Factors affecting population densities and increase rates of wild ungulates

Densities of bison were positively correlated with mean annual temperature (Fig. 8). From 1802-1993, annual temperature was the only factor significantly affecting the density of bison (Table 2). However, climatic variability explained only $9 \%$ of the total variation in bison numbers; thus, the factors underlying the major part of that variation were not detected. Population increase rate of bison depended on the political stability in the region (Fig. 9). Even short-term breakages of the administrative protection system caused rapid declines of the bison

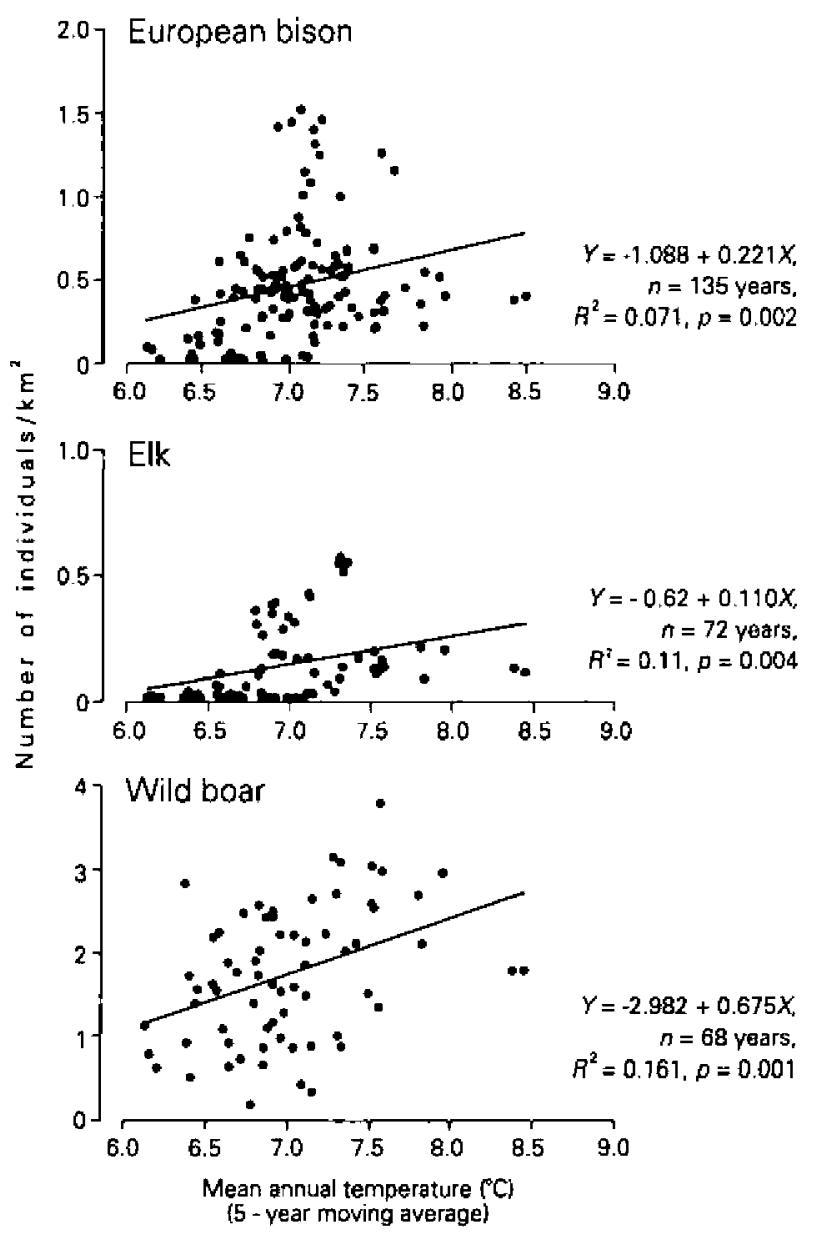

Fig. 8. Densities of European bison (1802-1993), elk (1798-1993), and wild boar (1890-1993) in relation to the mean annual temperature (5-year moving average) in BPF. Each point denotes one year. 
Table 2. Multiple regression analysis of the impact of various factors on densities of ungulates in BPF. Series of data cover years 1802-1993 in bison, and 1860, 1890-1993 in other ungulates. For wild boar two analyses were conducted: for 1860, 1890-1993 (whole material on boar numbers but incomplete data on snow cover and acorn crops), and for 1960-1993 (information on acorn crops and snow cover available). Semipartial correlation squared $\left(s r^{2}\right)$ expresses the unique contribution of a given factor (independent variable) as a proportion of the total variance explained of the ungulate numbers (dependent variable). ( + ) positive correlation, ( - ) negative correlation. Significance of independent variables: ${ }^{*} p<0.05,{ }^{* *} p<0.01,{ }^{* * *} p<0.001$

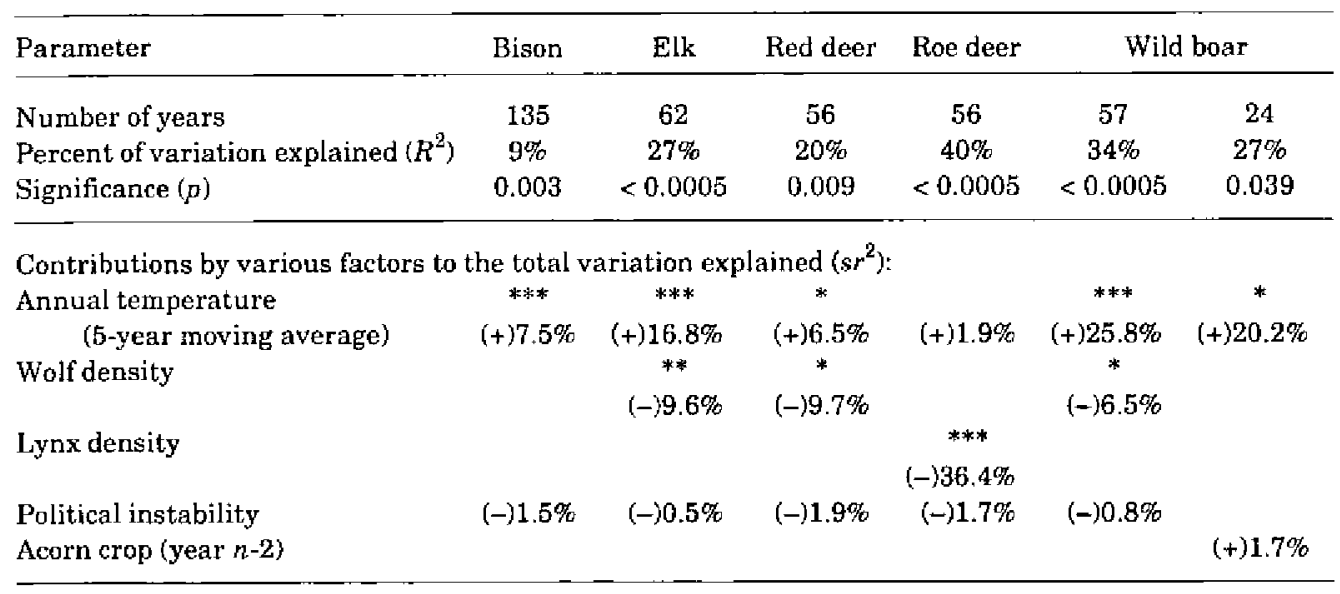

population. If we exclude years of warfare, the population increase of bison was negatively correlated to its own density and to the total biomass (per unit area) of other wild ungulates (Fig. 10). Indeed, a strong density dependence was detected in the time series of bison abundance (Pollard, Lakhani and Rothery's randomization test, $p=0.001$ ). The multiple regression analysis has shown that political instability, own density of bison, and total biomass of other wild ungulates explained $77 \%$ of the total variation in the increase rate of bison population (Table 3 ). Large predators affected neither density nor population increase rate of bison.

It may be suspected that the extensive grazing of domestic cattle in BPF in 1860-1970 also had a competitive effect on bison. We had very scarce data on cattle numbers, but for a rough analysis, indices of cattle abundance were read from regression lines showing multiannual trends in cattle increase or decline in BPF (see Fig. 4). However, inclusion of this index as an additional independent variable to the multiple regression increased the total variation explained only very slightly from $77 \%$ to $79 \%$ (cf Table 3 ).

In 1798-1993, densities of elk were positively correlated with the mean annual temperature (Fig. 8) and, negatively, with the densities of wolves ( $Y=0.192-$ $0.024 X, R^{2}=0.102, n=62$ years, $p=0.012$ ). Multiple regression analysis revealed that $27 \%$ of variation in elk densities was explained by three factors: temperature, wolf densities, and political instability in the region of BPF (Table 2). The last one was not significant in the whole time series; humans markedly affected the 
Table 3. Multiple regression analysis of the impact of various factors on population increase rates (3-year moving average) of ungulates in BPF (1890-1993). For bison two analyses were done: for 1802-1993 (whole material on bison numbers but incomplete data on biomass of other ungulates) and 1890-1993 (information on numbers of other ungulates available). Also, for wild boar two analyses were conducted: for 1890-1993 and for 1960-1993 (see explanation to Table 2). In the shorter series (23 years), annual records (and not moving averages) of population increase rate and densities of wild boar were used. See Table 2 for explanation of statistical denotations.

\begin{tabular}{|c|c|c|c|c|c|c|c|}
\hline \multirow{2}{*}{$\frac{\text { Parameter }}{\text { Number of years }}$} & \multicolumn{2}{|c|}{ Bison } & \multirow{2}{*}{$\begin{array}{c}\text { Elk } \\
52\end{array}$} & \multirow{2}{*}{$\frac{\text { Red deer }}{40}$} & \multirow{2}{*}{$\frac{\text { Roe deer }}{44}$} & \multicolumn{2}{|c|}{ Wild boar } \\
\hline & 97 & 49 & & & & 44 & 23 \\
\hline Percent of variation & & & & & & & \\
\hline explained $\left(R^{2}\right)$ & $42 \%$ & $77 \%$ & $34 \%$ & $60 \%$ & $45 \%$ & $33 \%$ & $75 \%$ \\
\hline Significance $(p)$ & $<0.0005$ & $<0.0005$ & $<0.0005$ & $<0.0005$ & $<0.0005$ & 0.003 & $<0.0005$ \\
\hline \multicolumn{8}{|c|}{ Contributions by various factors to the total variation explained $\left(s r^{2}\right)$ : } \\
\hline Density of own species & $* *$ & $* * *$ & $*$ & $* * *$ & $* *$ & $* * *$ & $* *$ \\
\hline (3-year moving average) & $(-) 4.2 \%$ & $(-) 11.4 \%$ & $(-) 7.6 \%$ & $(-) 29.0 \%$ & $(-) 11.2 \%$ & $(-) 22.2 \%$ & $(-) 13.2 \%$ \\
\hline \multicolumn{8}{|l|}{ Biomass of other wild } \\
\hline ungulates (3-year & & $*$ & $* *$ & & & & \\
\hline moving average) & & $(-) 2.8 \%$ & $(-) 12.9 \%$ & & & & \\
\hline \multirow[t]{2}{*}{ Political instability } & *** & $* * *$ & & & & & \\
\hline & $(-) 35.7 \%$ & $(-) 61.9 \%$ & $(-) 0.5 \%$ & $(-) 2.2 \%$ & $(-) 5.0 \%$ & $(-) 2,4 \%$ & \\
\hline Annual temperature & & & & *** & * & $* *$ & \\
\hline (5-year moving average) & & & & $(+) 14.6 \%$ & $(+) 7.8 \%$ & $(+) 19.9 \%$ & \\
\hline Acorn crop in the & & & & & & & $* * *$ \\
\hline preceding year & & & & & & & $(+) 27.2 \%$ \\
\hline Combined density & & & & **** & & & \\
\hline of wolf and lynx & & & & $(-) 27.5 \%$ & & & \\
\hline \multirow[t]{2}{*}{ Lynx density } & & & & & $* * *$ & & \\
\hline & & & & & $(-) 32.6 \%$ & & \\
\hline Wolf density & & & & & & $(-14.7 \%$ & \\
\hline Snow cover & & & & & & & $(-) 2.7 \%$ \\
\hline
\end{tabular}

rate of elk population increase only during the war (Fig. 9). In years of peace, the annual increase of elk numbers was significantly correlated with the population density of elk and the total biomass of other wild ungulates (Fig. 10). Randomization test has also detected a strong density dependence in the time series of elk numbers $(p=0.001)$. In the multiple regression analysis, $34 \%$ of variation in the rate of annual increase of elk population were explained, predominantly by variation in biomass of all other wild ungulates and elk density (Table 3 ).

Red and roe deer were characterized by both numbers and rates of population increase that were significantly affected by predation. Dramatic growths and declines of red deer numbers in 1890-1993 alternated with those of wolf density (Fig. 11). We emphasize, however, that over most of the time, human action determined those fluctuations (see Jędrzejewska et al. 1996). Extermination of wolves in the $1870 \mathrm{~s}-1890 \mathrm{~s}$ and persistent shooting of all immigrant wolves until 

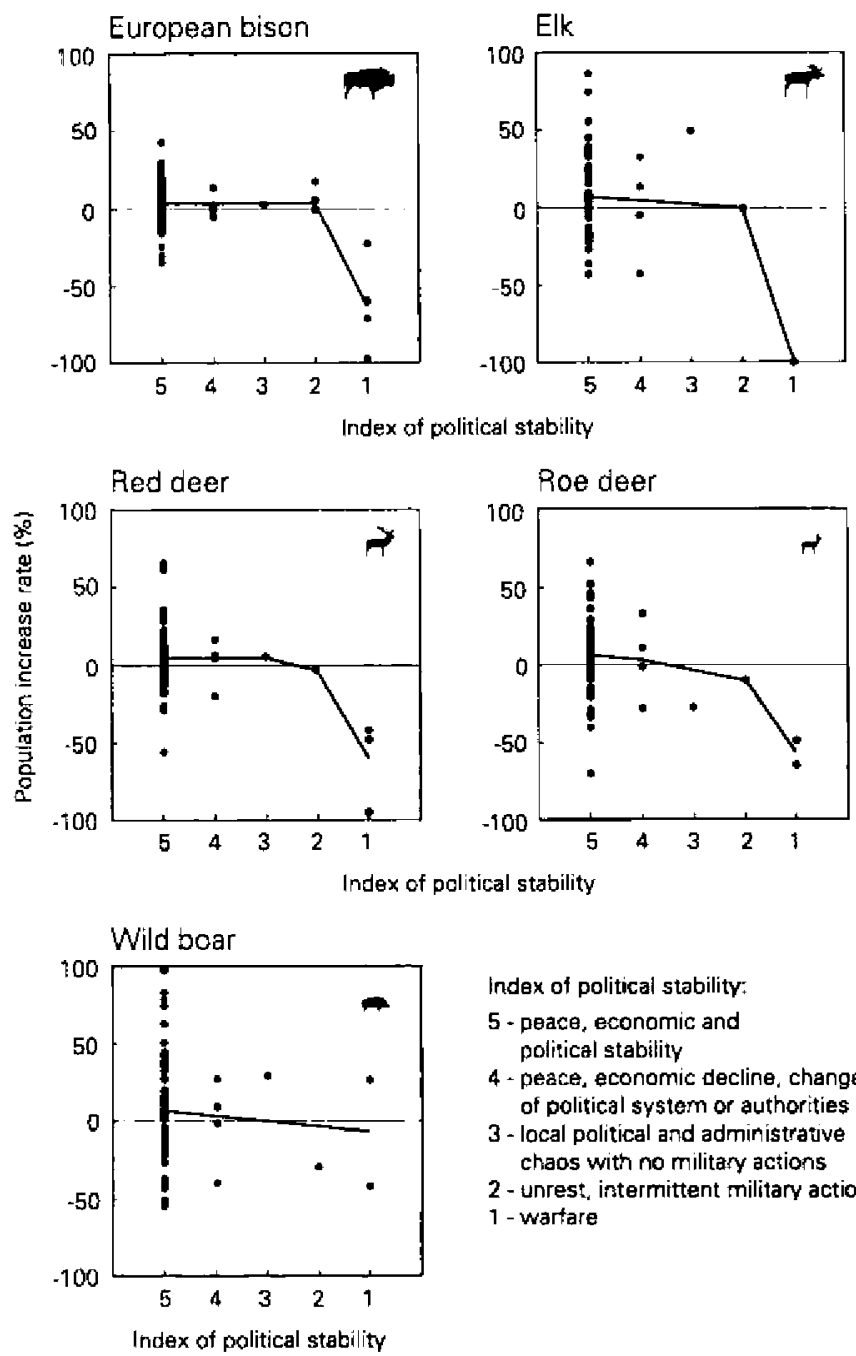

Index of political stability

5 - peace, economic and political stability

4- peace economic decline change of political system or authorities 3 - local political and administrative chaos with no military actions

2 - unrest, intermittent military actions

1 - wartare

Fig. 9. Rates of annual population increase of ungulates in relation to an arbitrary index of political stability in the region of BPF in 1809-1993. Each point denotes one year. Lines join the mean values in classes of political stability.

1915 had 'cleared the ground' for reintroduction of red deer and were conducive to their exponential increase. After 1915, within few years of warfare, red deer became nearly extirpated by humans, whereas wolves, relieved from control, rapidly resettled in the area. After a short period of resumed control (in the 1930s), wolves increased again during World War II. For about 30 years of high numbers of wolves (1920-1950), red deer densities remained very low. Extermination of wolves after WW II coincided with fast increase of red deer numbers. In the recent 
European bison

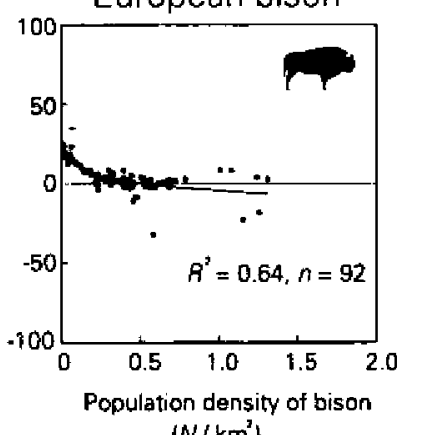

( $\left.N / \mathrm{km}^{2}\right\}$

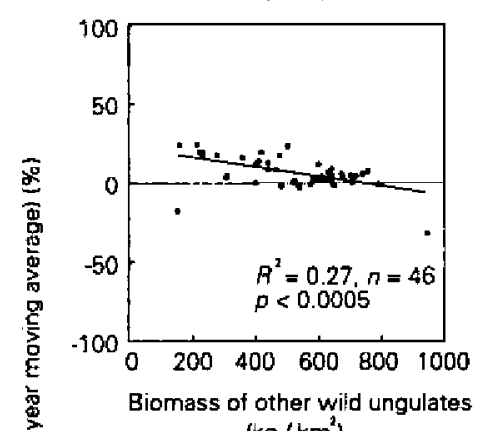

$\left(\mathrm{kg} / \mathrm{km}^{2}\right)$

Roe deer

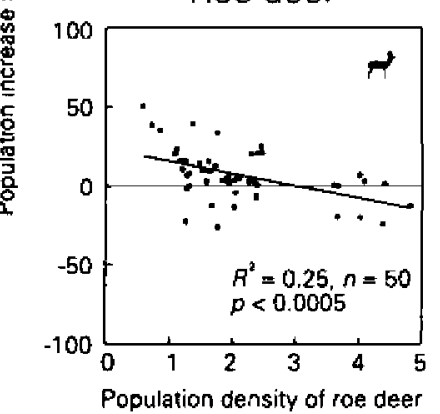

$\left(N / \mathrm{km}^{7}\right)$

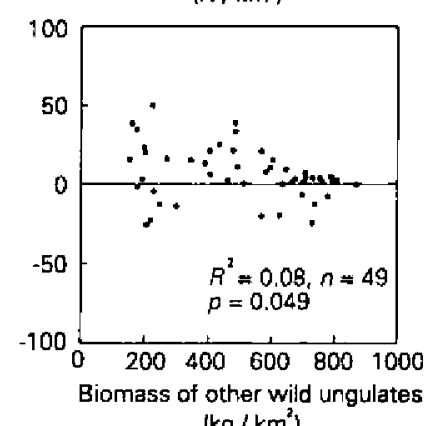

Elk

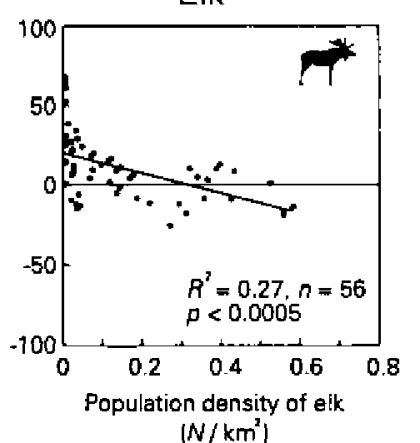

(N/ $\left.\mathrm{km}^{2}\right)$

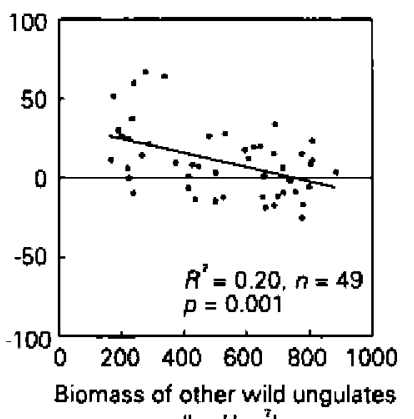

$\{\mathrm{kg} / \mathrm{km}$ )

Wild boar

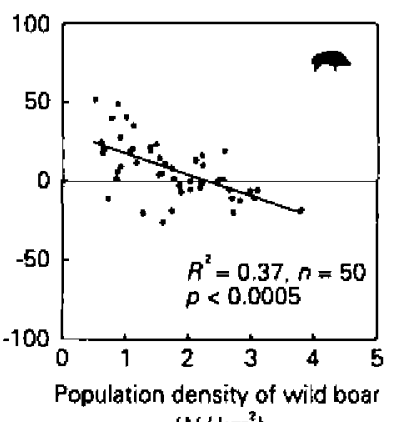

$\left(\mathrm{N} / \mathrm{km}^{\mathrm{2}}\right)$

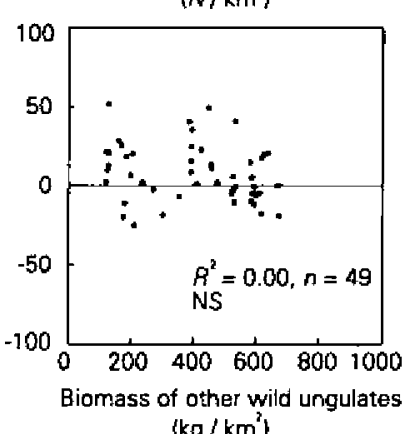

Red deer

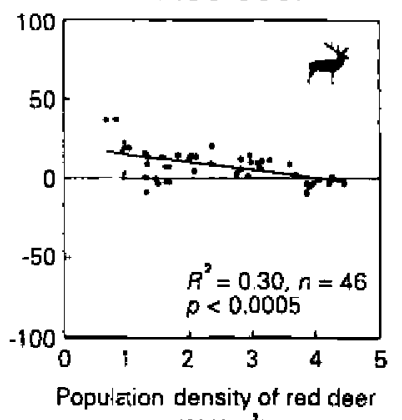

[N/ $\mathrm{km}$ ]

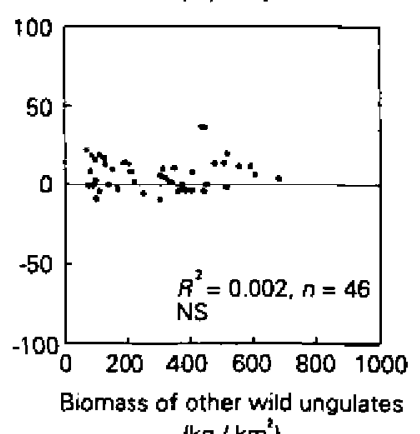

$\left\{\mathrm{kg} / \mathrm{km}^{2}\right\}$

Fig. 10. Rates of annual population increase (3-year moving average) of ungulates in relation to their own density (upper panels in each species) and biomass of all other wild ungulates (lower panels). 


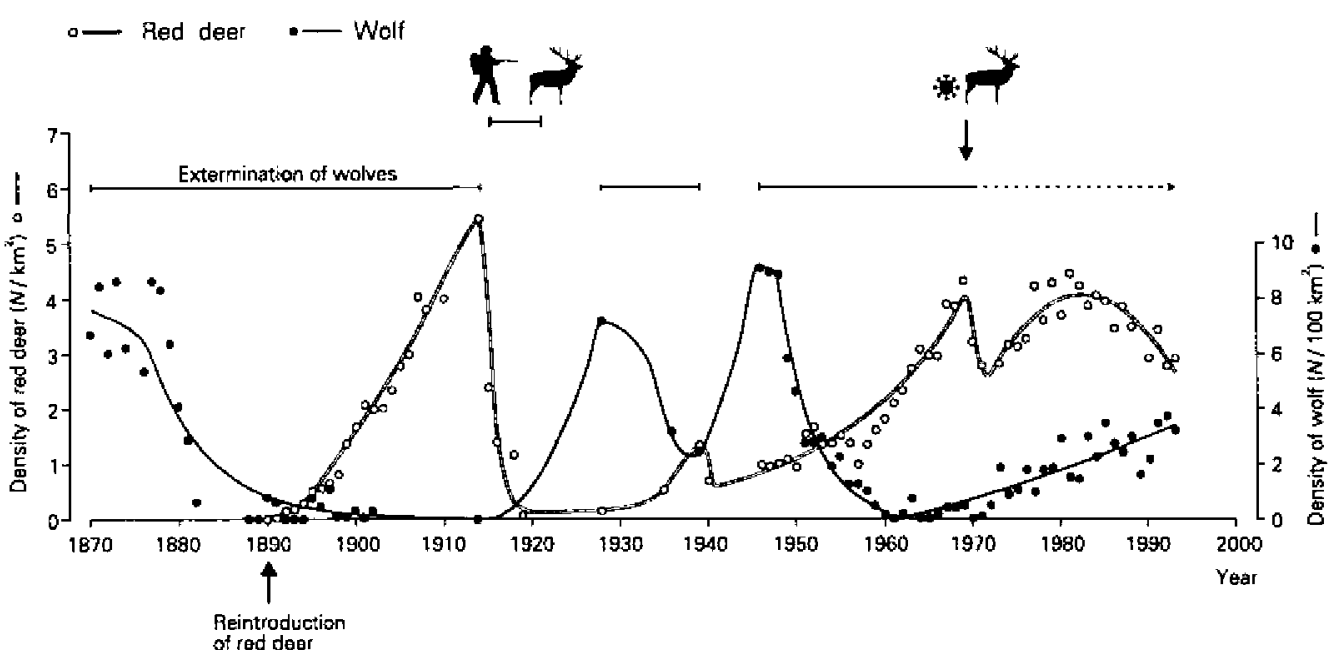

Fig. 11. Population dynamics of red deer and wolf in BPF in 1870-1993. Periods of wolf extermination are marked by thin lines, and years of heavy though not exterminating control by a thin broken line. Years of overexplnitation of red deer by poachers and soldiers during World War I are marked by a thick line. Arrow and snowflake denote decline of red deer numbers caused by the severe winter of 1969/70 (cf Fig. 3). Points are empirical data on red deer and wolf densities, and lines are smoothed population dynamics.

decades (1980s and 1990s), heavy but not exterminating harvest of wolves in the Belarussian part of the Forest and its protection in the Polish part allowed for persistence of wolf population at a level of about $40 \%$ of maximum recorded densities and even for steady increase of wolf numbers (Fig. 11). In 1897-1993, the densities of red deer were negatively correlated with those of wolves (Fig. 12). Multiple regression analysis revealed that also in comparison to other factors, wolf predation was the strongest determinant of red deer numbers (Table 2). Another significantly contributing factor was the mean annual temperature (positive effect). Variation in lynx numbers had no effect on red deer densities.

Density-dependent decline in the increase rate of deer population was well marked (Fig. 10). The regression equation indicates that red deer population growth would be halted by competition for food at mean densities of $4 \mathrm{inds} / \mathrm{km}^{2}$. Thus, densities of red deer attained around 1914, 1967-1969, and in 1975-1985 approached the upper level set by food limitation. Also, randomization test showed highly significant evidence for density dependence in the data on red deer numbers $(p=0.001)$. No decline in red deer population growth was observed with increasing biomass of all other ungulates (Fig. 10). The rate of deer population increase was negatively correlated with pooled densities of wolf and lynx (Fig. 12). As shown by multiple regression analysis, four factors (the most important being intraspecific competition and predation) explained totally $60 \%$ of variation in population 

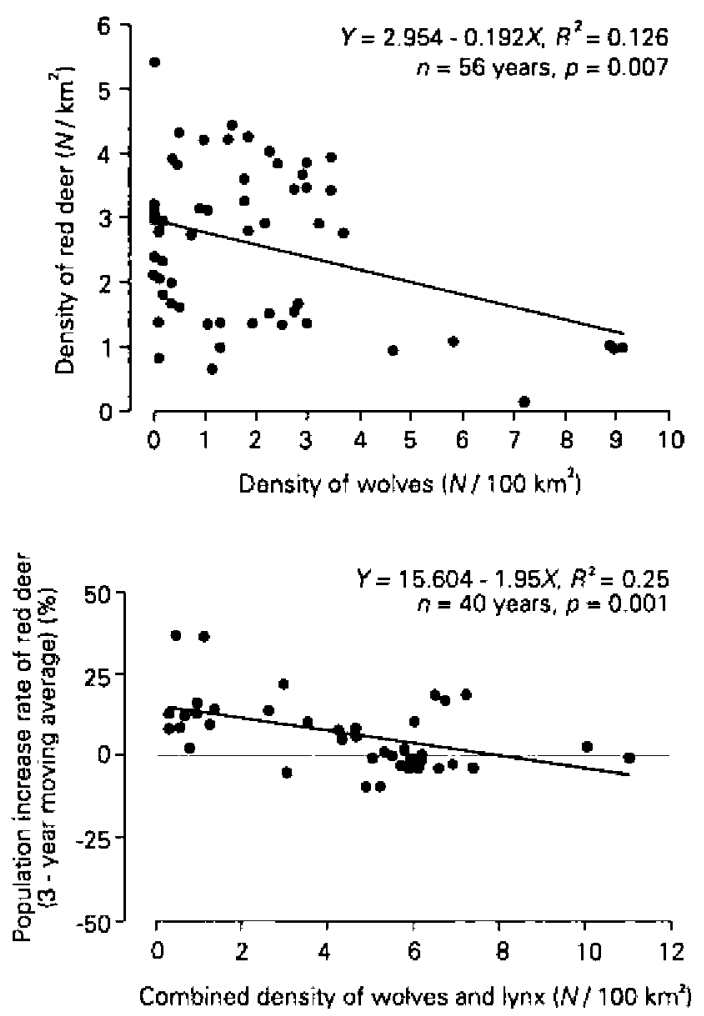

Fig. 12. Density of red deer in relation to wolf density in BPF in 1897-1993 (upper graph). Each point denotes one year. Population increase rate of red deer in relation to combined density of large predators (wolves and lynx) in BPF (lower graph).

increase rate of red deer in the entire series of data (Table 3). Human impact on red deer population growth was highly destructive in the years of wars, only (Fig.9).

The population of roe deer was fairly stable over the last century although it underwent two eruptions of numbers, both coinciding with extermination of the lynx, the roe deer's main predator (Fig. 13). However, the rapid declines of roe deer numbers (starting in 1915 and 1969/70) were not triggered by changes in predation rates, but by human overexploitation and a harsh winter, respectively. Interestingly, both declines coincided with the recovery of the lynx population relieved from persecution (see Jędrzejewski et al. 1996). In 1897-1993, when data on both roe deer and lynx numbers are available, densities of roe deer negatively correlated with those of the lynx (Fig. 14). Also, in the multiple regression analysis, lynx numbers appeared the essential factor shaping the densities of roe deer (Table 2). Variation in the mean annual temperature (positive effect) and political instability (negative effect) added very little to the total variation explained. 


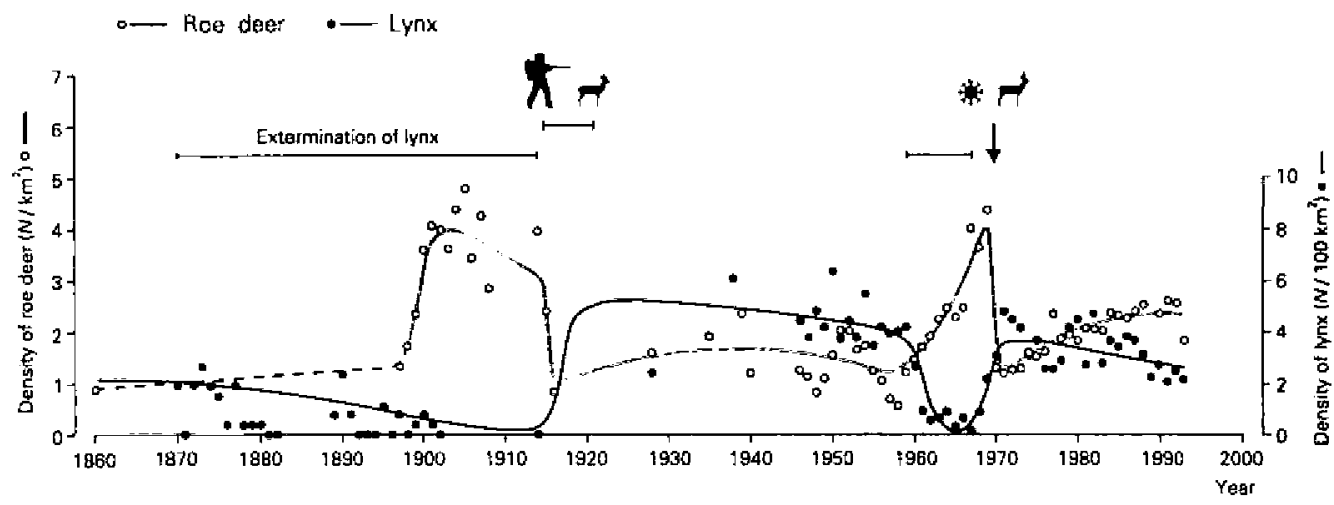

Fig. 13. Population dynamics of roe deer and lynx in BPF in 1860-1993. Periods of lynx extermination marked by thin lines. Years of overexploitation of roe deer by poachers and soldiers during World War I are marked by a thick line. Arrow and snowflake denote decline of roe deer numbers caused by the severe winter of $1969 / 70$. Points are empirical data on roe deer and lynx densities, lines are smoothed population dynamics.
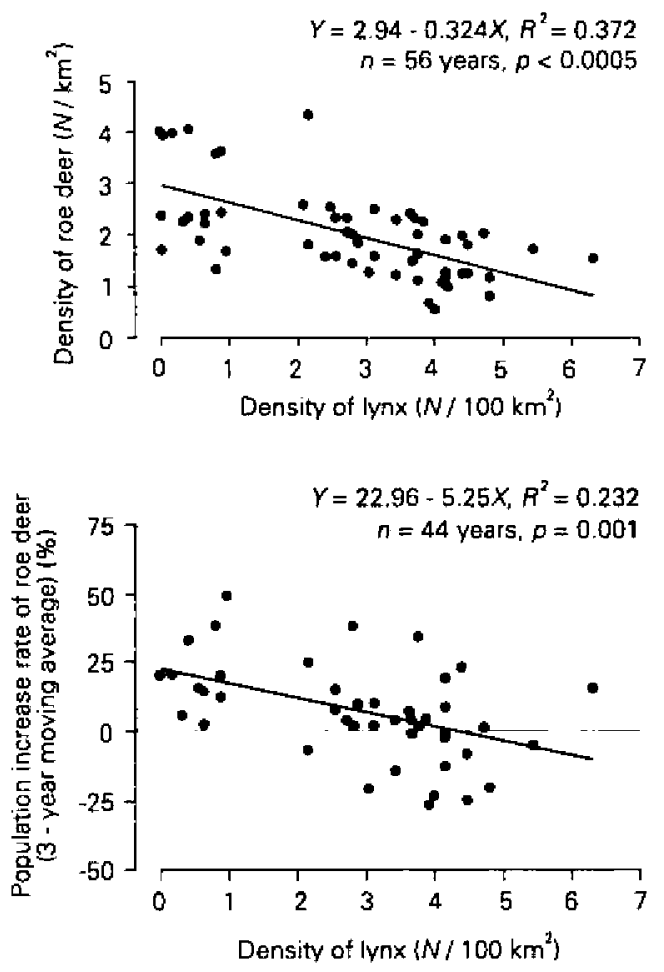

Fig. 14. Density of roe deer in relation to lynx density in BPF in 1896-1993 (upper graph) and population increase rate of roe deer in relation to the density of lynx in BPF (lower graph). 
Similarly, the population increase rate of roe deer was shaped predominantly by lynx density (Fig. 14). Furthermore, density-dependent decline in the rate of population growth was observed in roe deer (Fig. 10). The existence of density dependence in the time series of roe deer abundance was also evidenced by randomization test $(p=0.001)$. In the whole series of data, roe deer increase rate did not correlate with the biomass of other wild ungulates (Fig. 10). Political instability, especially the years of war caused dramatic declines in roe deer numbers (Fig. 9). In the multiple regression analysis, four factors explained $45 \%$ of the total variation in roe deer population growth from year to year; most important was lynx density (Table 3).

Densities of wild boar were positively correlated with mean annual temperature (Fig. 8). Both in the whole series of data on boar numbers (1860, 1890-1993) and in the analysis restricted to the period 1960-1993, the mean annual temperature played the primary role on shaping the densities of wild boar (Table 2). Another significant factor (but only in the long series of data) was wolf density (negative effect). Population increase rate of wild boar strongly correlated with the crop of oak seeds of the preceding autumn-winter season (Fig. 15). After 1945, heavy crops of oak seeds (wild boars' main food) occurred in 1949-1950, 1958, 1967, 1976, 1982, and 1989 (Pucek et al. 1993). Very pronounced increases in wild boar numbers were observed one year after the fall of acorn and were followed by substantial declines a year later (see Lebedeva 1956, and Okarma et al. 1995, for analysis of wild boar response to heavy crop of acorns). Marked declines of boar numbers were observed also during severe winters 1964/65, 1969/70, and 1986/87 (see Fig. 4). Furthermore, interspecific competition had a suppressing effect on

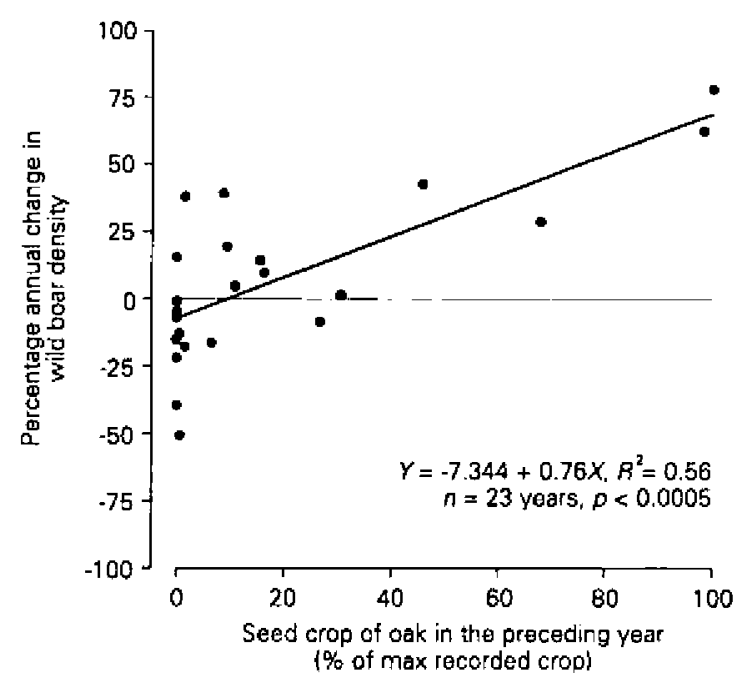

Fig. 15. Population increase rate of wild boar (from year $n-1$ to $n$ ) in relation to the crop of oak seeds in the preceding autumn-winter season (in calendar year $n-2$ ) in 1960-1993. 
the increase rate of wild boar population (Fig. 10). Indeed, a very strong density dependence in the time series of boar numbers was detected by the randomization test $(p=0.001)$. Compared to other ungulates, wild boar population growth was not lower during years of political instability (Fig. 9), obviously thanks to very high breeding potential of this species. Snow cover negatively affected increase rate of wild boar population ( $Y=19.1-1.236 X, R^{2}=0.09, p<0.05, n=43$ years), and the regression equation indicated that mean annual increase of boar population was $19 \%$ at snowless winters and it approached zero when mean daily snow cover in the cold season exceeded $15 \mathrm{~cm}$. In 1948-1993, the average snow depth was $10 \mathrm{~cm}$, thus wild boar population should have increased at a mean rate of $7 \%$ annually. In fact, despite wild fluctuations caused by acorn crops, boar numbers showed a trend of increase (see Fig. 4). Multiple regression analysis conducted for the whole series of data indicated that own density of boar and mean annual temperature were crucial factors affecting the rate of population increase of wild boar (Table 3). In the shorter series (1960-1993) data on acorn crops and snow cover were available; then, acorns appeared most important. Together with boar density and snow cover, it explained $75 \%$ of the total variation in population increase rate of wild boar.

In 1897-1993, the total crude biomass of wild ungulates varied 18-fold: from 65 to $1180 \mathrm{~kg} / \mathrm{km}^{2}$ (see Fig. 6). Multiple regression analysis revealed that only two factors significantly correlated with biomass of wild ungulates: mean annual temperature (positive effect) and abundance of large predators (negative effect). The relationship was described by the equation: $B=-949.06+239.81 T-36.30 P$ ( $n=54$ years, $R^{2}=0.456, p<0.0005$ ), where $B$ - total biomass of wild ungulates $\left(\mathrm{kg} / \mathrm{km}^{2}\right), T-5$-year moving average of the mean annual temperature $\left({ }^{\circ} \mathrm{C}\right)$, and $P$ - combined density of wolf and lynx $\left(N\right.$ inds $\left./ 100 \mathrm{~km}^{2}\right)$. In the series of 54 years for which data are available, the smoothed records of annual temperature varied from 6 to $8.5^{\circ} \mathrm{C}$ and abundance of large predators from 0 to 13.7 inds $/ 100 \mathrm{~km}^{2}$ (wolves and lynxes combined). The relative roles of the two independent variables were very similar: $s r^{2}=24.5 \%$ for temperature and $23.9 \%$ for predator numbers.

\section{Discussion}

Reliability of estimates and reconstructions of ungulate numbers

Undoubtedly, the estimates of bison numbers (the whole series available) are most accurate of all species of ungulates. As regards other species of wild ungulates, the data from 1946-1993 were several times verified by drive censuses, the most accurate technique available for censusing forest ungulates (Pucek et al. 1975, Aulak and Goszczyński 1986, Dzięciolowski et al. 1995). All possible crosschecking of data in particular years, and estimates of error based on regression analysis (details in Appendices II-V) indicate that, in 1946-1993, the error of estimate and reconstruction was from $10 \%$ at high numbers to $50 \%$ at low 
numbers of ungulates. In our analysis of historical data (before 1945), we had to rely on published reports but wherever possible, the reported numbers of ungulates were compared to other - descriptive and quantitative - information (eg hunting quotas). Thus, we think that the temporal changes and the level of wild ungulate abundance are documented reliably. Least reliable are the numbers of cattle pastured in $\mathrm{BPF}$, because numerical data were only available for 10 years (but luckily they included the maximum and minimum numbers recorded). Therefore, although the trend in cattle abundance in BPF is manifest, the numbers in particular years have to be treated as rough approximations.

As regards the community approach, the following points should be mentioned. All measures of abundance of wild ungulates are mid or late winter estimates (ie at the time of seasonally lowest numbers of ungulates). In the case of livestock, the available data are summer numbers (ie seasonally highest numbers). In winters, livestock were kept both at homesteads and at sheds and hay racks in the mown meadows along rivers in BPF. Their impact on the forest was negligible then. Therefore, comparing the summer numbers of cattle with winter numbers of wild ungulates may overestimate the role of cattle in the forest. However, this error is lowered by the fact that official numbers of cattle were underestimated. The percentage species (and biomass) structure of wild ungulate community (based on numbers) reliably approximates the relative abundance of each species. Data for the Polish part of BPF are supported by other sources: random samples of ungulate carcasses found between 1984-1994 (Okarma et al. 1995), visual observations of ungulates in BNP in 1986-1989 (Jędrzejewski et al. 1992), and hunting harvest. Furthermore, we emphasize that densities and biomass of ungulates shown in this paper are mean measures for the whole BPF, and the great spatial variation has not been analysed here (see Jędrzejewska et al. 1994 for detailed spatial analysis of the census in 1991). Generally, we believe that the entire series of data is a reliable approximation of mean values and their changes in the long time scale, but figures for particular years may be afflicted with substantial errors.

Multifactorial explanation of ungulate dynamics

The community of native wild ungulates of BPF includes species differing 20 times in crude body mass and 10 times in metabolic biomass (Table 4). Generally, larger species have slower reproduction rates then smaller ones but the wild boar outlies this relationship with faster reproduction compared to Artiodactyla of its size. The five studied species of ungulates forage on three major types of vegetal matter: (1) red deer, bison, elk and roe deer browse on twigs of shrubs and tree saplings; (2) roe deer, bison, red deer and elk graze on herbaceous ground vegetation, both under the forest canopy (predominantly dicotyledonous forbs) and in openings, clearcuts, river-side meadows and marshes (mainly monocotyledons); and (3) wild boar root the humus layer searching for bulbs, roots, fallen acorns, and soil invertebrates (Dzięciolowski 1970a, b, 1974, Gębczyńska and Krasińska 
1972, Kozlo 1975, Morow 1976, Gębczyńska 1980, Kossak 1983, 1991, 1992, Gębczyńska et al. 1991). Based on classification by Caughley and Sinclair (1994), we want to point at the differences between two kinds of food resources utilised by ungulates of the temperate forests: (1) browse and ground vegetation, and (2) acorn crop. Browse and ground vegetation exhibit no rapid year-to-year variation in abundance, hence they are predictable to consumers. Furthermore, the relationship between browse or ground vegetation and ungulates is interactive, ie ungulate dynamics reacts to the level of these resources but also the rate of renewal of browse and ground vegetation reacts to the number of animals using them. On the contrary, oak seed crops are extremely variable from year to year, with masts occuring at 6-9-year intervals and always followed by one or two barren years. Consumers of acorns have no influence on the rate of their renewal (reactive relationship), and hence do not influence on the amount of food available to the next generations. The two kinds of resources give bases to different population dynamics of ungulates feeding on them. Most variable from year to year, numbers of wild boar followed the variation in acorn crop, whereas all other species, feeding on more stable resources, exhibited multiannually relatively stable population dynamics.

After this brief description of ungulates and their resources, we attempt to interpret the mechanism of impact by each factor used as independent variable in the regression analyses. The analysed factors represented the roles of: (1) food (measured directly, ie acorn supply for wild boar, and indirectly, by climatic indices or expressed by slower increase rate at higher densities, interpreted as competition for food); (2) predation (approximated by the indices of wolf and lynx numbers); (3) weather conditions (direct impact of snow and temperature on mortality); and (4) humans (planned harvest and uncontrolled exploitation).

Density-dependent decline of ungulate population growth is assumed to reflect food competition (Messier 1991). Also, we think that the positive influence of temperature on all ungulates acted predominantly through improving food supply and feeding conditions. In 1948-1993, period of vegetative growth in BPF (ie number of days with mean daily temperature $>5^{\circ} \mathrm{C}$ ) lasted for 207.6 days, on average $(S D=10.8$ ), and it varied from 188 days in 1956 to 237 days in 1990 . Longer vegetative period and shorter duration of snow cover directly translate to better feeding conditions for all ungulates, particularly those obtaining part of or all their food from the ground layer. Moreover, variation in annual temperature causes long-term changes in food supply. Multiannual pattern of acorn crop is shaped by temperature, with mast years occurring at shorter intervals during periods of warming (Pucek et al. 1993). Most likely long-term trends in regeneration of deciduous trees and shrubs, including species of ungulates preferred browse, depend on climatic trends. This phenomenon, noted by forestry inventories and observations, needs thorough investigations. The direct impact of adverse weather conditions (especially severe winters with deep snow) on ungulate survival was 
also noted, but even then it acted together with forage deprivation (when snow is deep) and/or deterioration (during severe frost).

As regards the main factors responsible for population dynamics, the five studied species fell into three groups: (1) bison and elk, (2) red and roe deer, and (3) wild boar. Essential natural factors shaping bison and elk populations were mean annual temperature and competition. Checked in the shorter series of data (1948-1993), neither snow depth nor the mean temperature of cold season alone appeared to influence bison or elk densities and rate of increase. Also, direct recording of winter mortality of ungulates in 1984/85-1993/94 showed no correlation between bison or elk mortality and winter conditions (Okarma et al. 1995). Abundant supplementary fodder (hay stacks) has been provided for bison since at least the recent three centuries. This practice, continued to-day (Krasinski et al. 1994), has eliminated or reduced the negative impact of adverse winter conditions on bison survival. Thus, the positive influence of the mean annual temperature on bison and elk populations, found in this study, may act through improved supply and availability of forest food resources. Food was the prime natural factor limiting the population growth and densities of bison and elk in the temperate forests. Adults of these large ungulates have very high daily demands for food: $19-32 \mathrm{~kg}$ fresh weight in bison (Gębczynska and Krasinska 1972) and $16-20 \mathrm{~kg}$ in elk (Morow 1976). We propose that interspecific and intraspecific competition for food, acting through density-dependent decline of population increase, is the most reliable regulatory mechanism in bison and elk. The density at which population increase rate declined to zero may indicate the carrying capacity of Białowieza

Table 4. Basic biological features of five native ungulates of Bialowieża P'rimeval Forest. Sources of data: body masses - Dzięciolowski 1969, Miłkowski 1970. Pucek 1984, Krasińska 1988, Pielowski 1988; reproduction rates - Sablina 1955, Lebedeva 1956. L. Milkowski, unpubl., and authors' own data: Percent share in predators diet (whole reported range of multiannual and spatial variation in BPF is given) - Gavrin and Donaurov 1954, Geptner and Naumov 1972, p. 434, Bunevich 1988. Jędrzejewski et al. 1992, 1993, in prep., Jędrzejewska et al. 1994. Feeding ecology (browsing $=$ feeding on twigs of shrubs and small trees, grazing = feeding on ground vegetation: herbaceous vegetation and dwarf shrubs, rooting = obtaining food by moving the humus and upper layer of soil, and collecting food items from the ground - Dzięciolowski 1970b, Kozlo 1975, Morow 1976, Gębczyńska 1980, Gębezyńska et al. 1991

\begin{tabular}{|c|c|c|c|c|c|}
\hline Parameter & Bison & Elk & Red deer & Roe deer & Wild boar \\
\hline Mean body mass ( $\mathrm{kg}$ ) & 400 & 200 & 100 & 20 & 80 \\
\hline Metabolic body mass, $B M^{1175},(\mathrm{~kg})$ & 89 & 53 & 32 & 9 & 27 \\
\hline Feeding ecology: grazing $(\%)$ & 90 & 10 & 40 & 80 & - \\
\hline browsing $(x)$ & 10 & 90 & 60 & 20 & - \\
\hline rooting $(x)$ & - & - & - & - & 100 \\
\hline \multicolumn{6}{|l|}{ Annual reproduction rate } \\
\hline ( $N$ juv born/adult) & 0.17 & 0.40 & 0.43 & 0.66 & 0.93 \\
\hline Share in wolf diel (\%) & $0-1$ & $0-2$ & $11-83$ & $2-29$ & $11-39$ \\
\hline Share in lynx diet (\%) & 0 & 0 & $3-53$ & $40-81$ & $1-16$ \\
\hline
\end{tabular}


Forest for a given species of ungulate. If it is so, the densities of bison determined by food carrying capacity would be about $0.5 \mathrm{ind} / \mathrm{km}^{2}$. Maximum recorded densities of bison were about $1.5 \mathrm{ind} / \mathrm{km}^{2}$ in the absence of red deer (the 19th century), and $0.4 \mathrm{ind} / \mathrm{km}^{2}$ when red deer was present and when deliberate culling has been conducted (the 20th century). In elk, the respective densities were $0.6 \mathrm{ind} / \mathrm{km}^{2}$ (when no red deer in the community), and $0.2 \mathrm{ind} / \mathrm{km}^{2}$ (with red deer present). Carrying capacity of BPF for elk, as estimated from the regression equation (population increase rate versus density) would be about $0.3 \mathrm{ind} / \mathrm{km}^{2}$. Interestingly, after attaining densities near or above the carrying capacity of habitat, bison and elk populations began to decline. Predation did not limit the densities of bison and only weakly those of elk. This results from the fact that, in a multispecies community of ungulates, the two largest ungulates form a negligible contribution to predator's diets (Table 4).

Red and roe deer, species profoundly affected by predation, are the preferred prey to wolves and lynx, respectively (Table 4). It is noteworthy that the pattern of ungulate prey selection by wolves and lynxes described from Białowieza Primeval Forest is typical for temperate forests of the Palearctic region (Jędrzejewski et al. 1992, 1993, Okarma 1995). The cause-effect interpretation of the deer-predator correlations described in Results is corroborated by the fact that the long-term data represent a series of unintended experiments. First, each extermination or substantial reduction of predators was followed by increase in prey numbers. More importantly, an 'experiment' long postulated but so far never reported to had been done took place in BPF: reduction of prey numbers in the period of high numbers of predators (cf Skogland 1991, Van Ballenberghe and Ballard 1994). In 1915-1920, when wolves and lynxes quickly recolonised the forests of Białowieża, roe and red deer numbers had already been reduced by humans. Both wolf and lynx kept the populations of their main prey (red and roe deer, respectively) at low densities for 30-40 years, ic until the next temporary extermination of predators. In roe deer-lynx system, the same 'experiment' was 'replicated' when the severe winter of 1969/70 reduced the numbers of roe deer by $70 \%$. Again, high numbers of lynx hampered the recovery of roe deer population so much that 25 years later roe deer density was still half that recorded in 1969 . Further evidence of the crucial role of predation to red and roe deer was provided by our recent direct studies on the lynx and wolf impact on ungulates in 1991-1995 (Okarma et al. 1997, W. Jędrzejewski et al. in prep.). Densities of large predators and deer during the study period were moderate compared to the range of variation recorded in the recent two centuries. Every year, about $3 / 4$ of summer increase of red and roe deer due to reproduction was taken by large predators; in roe deer $64 \%$ by lynx and $9 \%$ by wolf; in red deer $40 \%$ by wolf and $33 \%$ by lynx.

Only when predators were exterminated, did the red deer and roe deer attain the level of densities at which they were regulated by competition for food. We think that about 5 inds $/ \mathrm{km}^{2}$ in each of these species, ie density with a mean growth rate approaching zero, is the level close to food carrying capacity of Bialowieza 
Forest to red and roe deer. It is likely that the rapid declines after 1915 and $1969 / 70$, although triggered by human overexploitation and very deep snow, were facilitated by already notable deterioration of ungulate conditions as a result of competition for food.

Wild boar represented pattern of population functioning different from those in the coexisting Artiodactyla. Their increase rate was shaped by highly variable supply of acorns and snow cover. The fluctuations of wild boar were short-term, rather dramatic, and were based on the fast reproduction rate of this species. However, the mean level of density around which wild boar numbers fluctuated, was determined by variation in the annual temperature. We think that the crucial component of the positive effect of climate warming on boar was the depth and duration of snow cover. To wild boar that get their food by rooting in the humus and upper layers of soil, deep snow obstructs the access to food however abundant. Predation, almost exclusively by wolves, played a minor role in limiting wild boar densities. In 1991-1995, wolves removed annually 10-17\% (on average 13\%) of the annual increase of wild boar due to breeding (W. Jędrzejewski et al. in prep.).

Coe et al. (1976), who examined the standing crop biomass of large mammalian herbivores in 30 localities in the savannas of east and southern Africa, found that it ranged from 405 to nearly $19930 \mathrm{~kg} / \mathrm{km}^{2}$ and was strongly positively correlated with the mean annual rainfall. Between-locality variation in rainfall explained $77 \%$ of the observed variation in the total biomass of large herbivores. Coe and co-workers interpreted this as a causal link operating through the effects of rainfall on primary production, ie food resources.

We propose that in the temperate zone it is not rainfall but mean annual temparture that is a limiting factor to ungulate abundance, operating both indirectly (through food supply) and directly. In Białowieża Forest, not only was the temporal variation of ungulate biomass related to trends in annual temperature but also the spatial variation in ungulate densities was determined by food resources. In the study conducted in 1991-1992 and covering the entire Polish part of BPF, we showed that combined densities of herbivorous ungulates (bison, elk, red deer, and roe deer) were positively correlated with the proportion of deciduous forests in various districts of BPF. Densities of wild boar were positively related to the proportion of mature treestands ( $>80$ years), obviously with numerous fructificating oaks (Jędrzejewska et al. 1994).

Sinclair (1985), who studied a multispecies community of ungulates in grasslands of Tanzania and Kenya, documented that various species were shaped by various dominant factors. The smallest species, Thomson's gazelle Gazella thomsoni and Grant's gazelle Gazella granti, were strongly influenced by predation. Medium-sized and large species, ie zebra Equus burchelli, topi Damaliscus korrigum, impala Aepyceros melampus, waterbuck Kobus defassa, warthog Phacochaerus aethiopicus, and possibly kongoni Alcelaphus buselaphus, were influenced by both predation and interspecific competition for food. Migratory wildebeest Connochaetus taurinus were limited by food. Our findings from the five-species 
community of ungulates in Bialowieża Forest showed similar pattern: small species were shaped largely by predation and large ones by inter- and intraspecific competition for food.

Acknowledgements: This paper is a result of cooperation agreement between the State National Park Belovezhskaya Pushcha (Belarus) and Mammal Research Institute, Polish Academy of Sciences (Bialowieza, Poland), and Bialowieża National Park (Poland). We sincerely thank Prof $Z$. Pucek and Drs $\mathrm{Cz}$. Okolów and V. Semakov for their support and providing facilities during our exchange visits in Bialowieza and Kamenyuki. We are grateful to the late A. Kawecki for his unpublished data on ungulate snowtracking in Bialowieza National Park in 1957-1962, and to Polish and Belarussian game wardens, and the staff of BNP, who took part in censuses of ungulates. L. Szymura and E. Bajko helped in analysing the snowtracking data. $K$, Zub drew the figures. Dr Cz. Okolów provided invaluable help in our search for archival data and sources. We thank Prof $R$. Śnieżko for her help with sources of climatic literature. Critical reviews by Profs Z. Pucek, S. Lovari, A. Eomnicki, Dr R J. Putman and two anonymous referees are gratefully acknowledged. We sincerely thank Prof A. tomnicki and $\mathrm{M}$. Cichon for writing a computer program for us to perform the randomization test. The study was financed by the grant KBN 444169102 .

\section{References}

Aulak W. and Babińska-Werka J. 1990. Estimation of roe deer density based on the abundance and rate of disappearance of their faeces from the forest. Acta Theriologica 35: 111-120.

Aulak W. and Goszczynski J. 1986. An inventory of hoofed populations driven through entire forest complexes. Wiadomości Ekologiczne 32: 403-413. [In Polish with English summary]

Bobek B. 1977. Summer food as the factor limiting roe deer population size. Nature 268: 47-49.

Bobrovskii P, 1863. [Materials on geography and statistics of Russia, collected by officers of the General Staff; Grodno District]. Sankt Petersburg. [In Russian]

Brincken J. 1828. Memoire descriptif sur la foret imperiale de Bialowieża en Lithuanie. N. Glucksberg, Varsovie: 1-127.

Buchalczyk T. 1980. The brown bear in Poland. [In: Bears - their biology and management. C. J. Martinka and K. L. McArthur, edsl. Bear Biologists Association Conference, Series 3: 229-232.

Bunevich A. N. 1988. [Dynamics of numbers and food of the wolf in Belovezha Primeval Forestl. Zapovedniki Belorussii 12: 108-113. [In Russian]

Caughley G. and Sinclair A. R. E. 1994. Wildlife ecology and management. Blackwell Scientific Publications, Boston: 1-334.

Chatfield C. 1989. The analysis of time series. An introduction. Fourth edition. Chapman and Hall, London: 1-241.

Coe N. J., Cumming D. H. and Phillipson J. 1976. Biomass and production of large African herbivores in relation to rainfall and primary production. Oecologia (Berlin) 22: 341-354

Dublin H. T., Sinclair A. R. E., Boutin S., Anderson M. and Arcese P. 1990. Does competition regulate ungulate populations? Further evidence from Serengeti, Tanzania. Oecologia (Berlin) 82: 283-288.

Dyakowski B. 1925. IOn ancient hunts and ancient game]. Wydawnictwo M. Arcta, Warszawa: 1-212. (Reprinted in 1989 by: Hubertus Classic Sp. z o.o., Warszawa) [In Polish]

Dzięciolowski R. 1969. [Weight of our lowland red deerl. Lowiec Polski 19: 4. [In Polish]

Dzięciolowski R. 1970a. Variation in red deer (Cervus elaphus L.) food selection in relation to environment. Ekologia Polska 18: 635-645.

Dzięciolowski R. 1970b. Foods of the red deer as determined by rumen content analyses. Acta Theriologica 15: 89-110.

Dzięciolowski R. 1974. Selection of browse twigs by moose. Acta Theriologica 19: 273-281.

Dzięciolowski R., Goszczyñski J., Wasilewski M. and Babiñska-Werka J. 1995. Numbers of red deer in the Slowinski National Park, Poland. Acta Theriologica 40:45-51. 
Faliński J. B. (ed) 1968. The national park in Bialowieża Primeval Forest. Państwowe Wydawnictwo Rolnicze i Leśne, Warszawa: 1-504. [In Polish]

Faliński J. B. 1986. Vegetation dynamics in temperate lowland primeval forests, Ecological studies in Bialowieża forest. Dr W. Junk Publishers, Dordrecht: 1-537.

Filonov, K. P. 1989. Ungulates and large predators in wildlife reserves. Izdatelstvo Nauka, Moskva: 1-246. [In Russian]

Gasaway W. C., Boertje R. D., Grangaard D. V., Kelleyhouse D. G., Stephenson R. O. and Larsen D. G. 1992. The role of predation in limiting moose at low densities in Alaska and Yukon and implications for conservation. Wild life Monographs 120: 1-59.

Gasaway W. C., Stephenson R. O., Davis J. L., Sherherd P. E. K. and Burris O. E. 1983. Interrelationships of wolves, prey and man in interior Alaska. Wildlife Monographs 84: 1-50.

Gavrin V. F. and Donaurov S. S. 1954. [The wolf in Belovezha Primeval Forestl. Zoologicheskij Zhurnal 33: 904-924. [In Russian]

Genko N. 1902-1903. [Description of Białowieża Primeval Forest and historical data about it]. Lesnoï Zhurnal 22(5): 1014-1056; 22(6): 1269-1302; 23(1): 22-56. [In Russian]

Geptner V. G. and Naumov N. P. (eds) 1972. [Mammals of the Soviet Union, Vol. II, part 2, Predators (hyenas and cats)]. Izdatelstvo Vysshaya Shkola, Moskva: 1-551. [In Russian]

Gębczyriska Z. 1980. Food of the roe deer and red deer in the Białowieża Primeval Forest. Acta Theriologica 25; 487-500.

Gębczyńska Z., Gębczyński M. and Martynowicz E. 1991. Food eaten by the free-living European bison in Białowieza Forest. Acta Theriologica 36: 307-313.

Gębczyriska Z. and Krasińska M. 1972. Food preferences and requirements of the European bison. Acta Theriologica 17; 105-117.

Gloger Z. 1881. [Excursion to Bialowieża]. Biblioteka Warszawska, Pismo poświęcone naukom, satukom i przemyslowi 161: 424-432. [In Polish]

Gordiyuk N. M. 1985. Winter ecology of Cervus elaphus sibiricus in south Urals. Zoologicheskif Zhurnal 64: 98-106. [In Russian with English summaryl

Hartman W. 1939. (Burning of potash, primitive bee-keeping, and hunting in ancient Biatowieża Primeval Forest]. Echa leśne 15(7): 154; 15(8): 177-178; 15(9): 205. [In Polish]

Hedemann O. 1935. [Ordinance of Paul I on elk]. Echa leśne 20: 9. [In Polish]

Hedemann O. 1936. [From ancient Bialowieża. Repercussions of wars]. Echa leśne 13: 2-3. [In Polish]

Hedemann O. 1939. L'histoire de la foret de Bialowieza (jusqu'a 1798). Institut de recherches des forets domaniales, Travaux et comptes rendus, Ser. A, 41: 1-310. Warszawa. [In Polish with French summary]

Henttonen H., Oksanen T., Jortikka A, and Haukisalmi V. 1987. How much do weasels shape microtine cycles in the northern Fennoscandian taiga? Oikos 50: 353-365.

Hussovianus N. 1523. Carmen de statura, feritate ac venatione bisonatis. H. Vietor, Cracow. [In Latinl (Reprinted in 1994 by: Publishing Division of Bialowieża National Park, Bialowieża, in Latin and Polish)

Jarocki F. P. 1830. [About Bialowieża Primeval Forest and its more prominent animals]. Warszawa. [In Polish]

Jędrzejewska B., Bunevich A. N. and Jędrzejewski W. 1995. Observations of brown bear Ursus arctos in Białowieża Primeval Forest in 1948-1950. Parkj Narodowe i Rezerwaty Przyrody 14(4): 87-90. [In Polish with English summary]

Jędrzejewska B., Jędrzejewski W., Bunevich A. N., Miłkowski L. and Okarma H. 1996. Population dynamics of wolves Canis lupus in Bialowieza Primeval Forest (Poland and Belarus) in relation to hunting by humans, 1847-1993. Mammal Review 26: 103-126.

Jędrzejewska B., Okarma H., Jędrzejewski W. and Miłkowski L. 1994. Effects of exploitation and protection on forest structure, ungulate density and wolf predation in Bialowieża Primeval Forest, Poland. Journal of Applied Ecology 31: 664-676. 
Jędrzejewski W. and Jędrzejewska B. 1995. Proposed National Park of Bialowieża Primeval Forest. Chrońmy Przyrode Ojczysta 51(3): 16-36. [In Polish with English summary]

Jędrzejewski W., Jędrzejewska B., Okarma H, and Ruprecht A. L. 1992. Wolf predation and snow cover as mortality factors in the ungulate community of the Biatowieza National Park, Poland Oecologia (Berlin) 90: 27-36.

Jędrzejewski W., Jędrzejewska B., Okarma H., Schmidt K., Bunevich A. N. and Milkowski L. 1996 Population dynamics (1869-1994), demography, and home ranges of the lynx in Bialowieza Primeval Forest (Poland and Belarus). Ecography 19: 122-138.

Jędrzejewski W., Schmidt K., Miłkowski L., Jędrzejewska B. and Okarma H. 1993. Foraging by lynx and its role in ungulate mortality: the local (Bialowieza Forest) and the Palaearctic viewpoints. Acta Theriologica 38: $385-403$.

Karcov G. 1903. (Beloyezha Primeval Forest. Historical description, contemporary game management, and monarchial hunts in the Forest]. A. Marks, Sankt Petersburg: 1-414. [In Russian]

Karpiński J. J. 1951. [The elk (Alces alces L.) in Biatowieża Primeval Forest]. Chrońmy Przyrodę Ojczysta 11-12: 40-48. [In Polish]

Korochkina L. N. 1973. IRegion of occurrence and spatial distribution of European bison in Belovezha Primeval Forest]. Belovezhskaya Pushcha 7: 148-165. [In Russian]

Kossak S. 1983. Trophic relations of roe deer in a fresh deciduous forest. Acta Theriologica 28: $83-127$.

Kossak S. 1991. Environmental and intraspecific interrelation with the nutritional behaviour of roe deer (Capreolus capreolus L.) in forest environment. Prace Instytutu Badawczego Leśnictwa 723: 1-96. [In Polish with English summary]

Kossak S. 1992. Foraging habits and behaviour of moose calves in virgin forests. Acta Theriologica 37 : $51-61$.

Kozlo P. G. 1975. [Wild boar]. Izdatelstvo Uradzhai, Minsk: I-223. [In Russian!

Krasińska M. 1988. Hybrids of European bison and domestic cattle. Ossolineum, Prace habilitacyjne, Wroclaw: 1-188. [In Polish with English summary]

Krasiński Z. 1967. Free living European bisons. Acta Theriologica 12: 391-405.

Krasiński Z. A. 1978. Dynamics and structure of the European bison population in the Bialowieża Primeval Forest. Acta Theriologica 23: 3-48.

Krasińskj Z. A. 1993. Bison, a relict of ancient times. Publishing Division of Bialowieża National Park, Bialowieża: 1-18.

Krasiński Z. A., Bunevich A. N. and Krasińska M. 1994. Characteristics of the European bison populations in the Polish and Belarussian parts of the Bialowieza Forest. Parki Narodowe $i$ Rezerwaty Przyrody 13(4): 25-67. IIn Polish with English summaryl

Lebedeva L. S. 1956. [Ecological characteristics of the wild boar in Belovezha Primeval Forest]. Uchenye Zapiski Moskovskogo Gorodskogo Pedagogicheskogo Instituta im. V. P. Potemkina 61: 105-271. [In Russian]

McLaren B. E. and Peterson R. O. 1994. Wolves, moose, and tree rings on Isle Royale. Science 266: $1555-1558$.

Messier F. 1991. The significance of limiting and regulating factors on the demography of moose and white-tailed deer. Journal of Animal Ecology 60: 377-393.

Milkowski L. 1969. [Experience in censusing big game in Bialowieża Primeval Forest], Łowiec Polski 22(1361): 4-5. [In Polish]

Miłkowski L. 1970. [Hunting in Bialowieża Primeval Forest. Guide for hunters]. Wydawnictwo Wojewódzki Ośrodek Infomacji Turystycznej, Białystok: 1-71. [In Polish]

Miłkowski L. 1982. [Management plan of hunting districts in forest administration units: Bialowieza, Browsk, Hajnówka in Bialowieża Primeval Forest for the period 01.01.1979-31.12.1988]. Unpublished report, Okręgowy Zarząd Lasów Pañstwowych w Białymstoku, Bialystok: 1-181. [In Polish]

Morow K. 1976. Food habits of moose from Augustów Forest. Acta Theriologica 21: 101-116. 
Okarma H. 1995. The trophic ecology of wolves and their predatory role in ungulate communities of forest ecosystems in Europe. Acta Theriologica 40: 335-386.

Okarma H., Jędrzejewska B., Jędrzejewski W., Krasinski Z. A. and Mitkowski L. 1995. The roles of predation, snow cover, acorn crop, and man-related factors on ungulate mortality in Bialowieża Primeval Forest, Poland. Acta Theriologica 40: 197-217.

Okarma H., Jędrzejewski W., Schmidt K., Kowalczyk R. and Jędrzejewska B. 1997. Predation of Eurasian lynx on roe deer and red deer in Białowieża Primeval Forest, Poland. Acta Theriologica 42: $203-224$

Paczos S. 1993. Thermic characteristic of the Polish territory in the last 200 years. IIn: Thermal characteristic of Poland. T. Kozlowska-Szczęsna, D. Limanówka, T. Niedżwiedź, Z. Ustrnul and $\mathbf{S}$. Paczos, edsl. Zeszyty Instytutu Geografii i Przestrzennego Zagospodarowania, Polska Akademia Nauk 18: 49-81. [In Polish with English summaryl

Peek J. M. 1980. Natural regulation of ungulates (what constitutes a real wilderness?) Wildlife Society Bulletin 8: 217-227.

Peterson R. O., Page R. E. and Dodge K. M. 1984. Wolves, moose, and the allometry of population cycles. Science 224: $1350-1352$.

Pielowski Z. 1988. [Roe deer], 3rd edn. Państwowe Wydawnictwo Rolnicze i Leśne, Warszawa: 1-293. [In Polish]

Pollard E., Lakhani K. H. and Rothery P. 1987. The detection of density-dependence from a series of annual censuses. Ecology 68: 2046-2055.

Priklonsky S. G. 1965. Coefficients to treat the data of winter transect method of census taking of game animals by their traces. Byulleten Moskovskogo Obshchestva Ispytatelei Prirody, Otdelenie Biologii 70(6): 5-12. [In Russian with English summary]

Pucek Z. 1984, [Key for identification of Polish mammals], 2nd edn. PWN - Polish Scientific Publishers, Warszawa: 1-384. [In Polish]

Pucek Z. 1991a. History of the European bison and problems of its protection and management. IIn: Transactions of the 18th Congress of International Union of Game Biologists, Kraków 1987. B. Bobek, K. Perzanowski and W. Regelin, eds]. Swiat Press, Kraków - Warszawa: 19-39.

Pucek Z. 1991b. Conservation strategy for European bison. Proceedings of the International Symposium Ongules/Ungulates 91 (Touluse-France, Sept. 2-6, 1991): 589-594.

Pucek Z., Bobek B., Labudzki L., Miłkowski L., Morow K. and Tomek A. 1975. Estimates of density and number of ungulates. Polish Ecological Studies 1(2): 121-135.

Pucek Z., Jędrzejewski W., Jędrzejewska B. and Pucek M. 1993. Rodent population dynamics in a primeval deciduous forest (Bialowieza National Park) in relation to weather, seed crop, and predation. Acta Theriologica 38: 199-232.

Putman R. J. and Sharma S. K. 1987. Long-term changes in New Forest deer populations and correlated environmental change. Symposia of the Zoological Society of London 58: 167-179.

Putman R. J., Langbein J., Hewison A. J. M. and Sharma S. K. 1996. Relative roles of density-dependent and density-independent factors in population dynamics of British deer. Mammal Review 26: 81-101.

Ratcliffe P. R. 1984. Population dynamics of red deer (Cervus elaphus L.) in Scottish commercial forests. Proceedings of the Royal Society of Edinburgh 82B: 291-302.

Rusakov O. S. and Timofeeva E, K, 1984. [The wild boar - ecology, resources, and economic importance in the north-west USSR]. Izdatelstvo Leningradskogo Universiteta, Leningrad: 1-206. [In Russian]

Sablina T. B. 1955. [Ungulates of Belovezha Primeval Forest]. Trudy Instituta Morfologii Zhivotnykh im. A. N. Severcova, Akademiya Nauk SSSR 15: 1-191. [In Russian]

Saether B,-E. 1997. Environmental stochasticity and population dynamics of large herbivores: a search for mechanisms. Trends in Ecology and Evolution 12: 143-149.

Schaller G. B. 1972. The Serengeti lion: a study of predator-prey relationships. University of Chicago Press, Chicago: 1-480. 
Seip D. R. 1992. Factors limiting woodland caribou populations and their interrelationships with wolves and moose in southeastern British Columbia. Canadian Journal of Zoology 70; 1494-1503

Shostak S. V. 1978. [Relationships of red deer numbers with other ungulates]. Zapovedniki Belorussii 2: 130-139. [In Russian]

Sinclair A. R. E. 1985. Does interspecific competition or predation shape the African ungulate community? Journal of Animal Ecology 54: 899-918.

Sinclair A. R. E. and Norton-Griffith M. 1982. Does competition or facilitation regulate migrant ungulate populations in the Serengeti? A test of hypotheses. Oecologia (Berlin) 53: 364-369.

Skogland T. 1985. The effects of density-dependent resource limitation on the demography of wild reindeer. Journal of Animal Ecology 54: 359-374.

Skogland T. 1991. What are the effects of predators on large ungulate populations? Oikos 61 $401-411$.

Skolasinski J., Piotrowska $K$. and Machaj Z. 1966. Investigations on the growth of the Polish black+and-white cattle. Roczniki Nauk Rolniczych B 87: 464-486. In Polish with English summaryl

Staines B. W. and Ratcliffe P. R. 1987. Estimating the abundance of red deer (Ceruts elaphtus L.) and roe deer (Capreolus capreolus L.) and their current status in Great Britain. Symposia of the Zoological Society of London 58: 131-152.

Tabachnick B. G. and Fidel] L. S. 1983. Using multivariate statistics. Harper and Row, New York: $1-509$.

Timofeeva E. K. 1974. [The elk]. lzdatelstvo Leningradskogo Universiteta, Leningrad: 1-168. [In Russian]

Tomialojc L., Wesolowski T. and Walankiewicz W. 1984. Breeding bird community of a primeval temperate forest (Bialowieza National Park, Poland). Acta Ornithologica 20: 241-310.

Tomiałojc L. and Wesolowski T. 1994. Die Stabilität der Vogelgemeinschaft in einem Urwald der gemässigten Zone: Ergebnisse einer 15jăhrigen Studie aus dem Nationalpark von Białowieża (Polen). Der Ornitologische Beobachter 91: 73-110.

Van Ballenberghe $V$. and Ballard W. B. 1994. Limitation and regulation of moose populations: the role of predation. Canadian Journal of Zoology 72: 2071-2077.

Vereshchagin N. K. and Rusakov O. S. 1979. [Ungulates of the north-west USSR]. Nauka, Leningrad: 1-308. [In Russian]

Voit E. 1917. Die Erischliessung des Urwaldes. Bialowies in Deutscher Verwaltung. Heft I. Paul Parey, Berlin: 9-54.

Więcko E. 1963. The Bialowieża Forest in 1795-1918. Kwartalnik Historii Kultury Materialnej 11(2); 297-352. [In Polish with English summary]

Więcko E. 1984. [Bialowieza Primeval Forest]. PWN - Polish Scientific Publishers, Warszawa: 1-309. [In Polish]

Wróblewski K. 1927. [European bison of Białowieża Primeval Forest]. Wydawnictwo Polskie, Poznań: 1-219. [In Polish]

Yurkevich I. D. 1941. [Belovezha Primeval Forest]. Lesnoe Khozaistvo 5: 34-42. [In Russian]

Received 7 September 1995, revised 15 November 1996, accepted 4 September 1997. 
Appendix I. Numbers of European bison in 1802-1993.

(1) Numbers of bison (censused by snowtracking and counts at winter feeding sites) in 1802-1919. Data from Karcov 1903, Dyakowski 1925, Wróblewski 1927, Hartman 1939, and Pucek 1991a, b. Numbers include free-living population and animals kept in enclosures (since the 1860s, usually about 20 inds), because it was not possible to consistently extract the captive bison from the total population (for details see Pucek 1991a). To calculate densities $\left(N\right.$ bison/ $\mathrm{km}^{2}$, shown in Fig. 4), numbers were divided by the area of BPF (it varied but we could not reconstruct year-to-year changes, so we used $1250 \mathrm{~km}^{2}$ for the period $1798-1945$ )

\begin{tabular}{|c|c|c|c|c|c|c|c|c|c|}
\hline Year & $N$ bison & Year & $N$ bison & Year & $N$ bison & Year & $N$ bison & Year & $N$ bison \\
\hline 1802 & 200 & 1835 & 845 & 1858 & 1434 & 1883 & 592 & 1904 & 708 \\
\hline 1809 & 350 & 1836 & 858 & 1860 & 1575 & 1884 & 384 & 1905 & 651 \\
\hline 1813 & 363 & 1837 & 860 & 1861 & 1447 & 1885 & 433 & 1906 & 663 \\
\hline 1816 & 483 & 1838 & 906 & 1862 & 1251 & 1886 & 427 & 1907 & 741 \\
\hline 1817 & 497 & 1839 & 932 & 1863 & 874 & 1887 & 438 & 1908 & 696 \\
\hline 1818 & 546 & 1840 & 817 & 1865 & 724 & 1889 & 380 & 1910 & 600 \\
\hline 1819 & 504 & 1841 & 946 & 1868 & 559 & 1890 & 403 & 1914 & 737 \\
\hline 1820 & 528 & 1843 & 984 & 1869 & 541 & 1891 & 479 & 1915 & 739 \\
\hline 1821 & 508 & 1844 & 993 & 1870 & 542 & 1892 & 491 & 1916 & 216 \\
\hline 1822 & 477 & 1845 & 1025 & 1871 & 528 & 1893 & 494 & 1917 & 167 \\
\hline 1823 & 515 & 1846 & 1095 & 1873 & 527 & 1894 & 496 & 1919 & 0 \\
\hline 1824 & 572 & 1848 & 1264 & 1874 & 536 & 1895 & 561 & & \\
\hline 1826 & 653 & 1849 & 1354 & 1875 & 558 & 1896 & 561 & & \\
\hline 1827 & 690 & 1850 & 1560 & 1876 & 561 & 1897 & 637 & & \\
\hline 1829 & 711 & 1851 & 1642 & 1877 & 559 & 1898 & 662 & & \\
\hline 1830 & 772 & 1852 & 1748 & 1878 & 565 & 1899 & 661 & & \\
\hline 1831 & 657 & 1853 & 1802 & 1879 & 574 & 1900 & 727 & & \\
\hline 1832 & 770 & 1854 & 1824 & 1880 & 579 & 1901 & 747 & & \\
\hline 1833 & 768 & 1856 & 1771 & 1881 & 574 & 1902 & 665 & & \\
\hline 1834 & 810 & 1857 & 1898 & 1882 & 600 & 1903 & 703 & & \\
\hline
\end{tabular}


(2) Numbers of bison in 1946-1994 (on December 31st each year). In the Polish and Belarussian parts, censuses were done by snowtracking and counts at winter feeding sites. Data from Korochkina 1973, Krasiński 1978, and Krasiński et al. 1994. Densities $\left(N / \mathrm{km}^{2}\right)$ were calculated using total number of bison (sum of numbers in the Polish and the Belarussian parts) and the area of BPF.

\begin{tabular}{|c|c|c|c|c|c|c|c|}
\hline $\begin{array}{l}\text { Winter } \\
\text { season }\end{array}$ & $\begin{array}{c}N \text { bison in } \\
\text { the Polish } \\
\text { part }\end{array}$ & $\begin{array}{c}N \text { bison } \\
\text { in the } \\
\text { Belarussian } \\
\text { part }\end{array}$ & $\begin{array}{c}\text { Area of } \\
\text { BPF } \\
\left(\mathrm{km}^{2}\right)\end{array}$ & $\begin{array}{l}\text { Winter } \\
\text { season }\end{array}$ & $\begin{array}{c}N \text { bison in } \\
\text { the Polish } \\
\text { part }\end{array}$ & $\begin{array}{c}N \text { bison } \\
\text { in the } \\
\text { Belarussian } \\
\text { part }\end{array}$ & $\begin{array}{l}\text { Area } \\
\text { BPF } \\
\left(\mathrm{km}^{2}\right)\end{array}$ \\
\hline $1945-1951$ & 0 & 0 & 1262 & $1972 / 73$ & 236 & 77 & 1418 \\
\hline $1951 / 52$ & 0 & 0 & 1269 & $1973 / 74$ & 253 & 82 & 1421 \\
\hline $1952 / 53$ & 2 & 7 & 1277 & $1974 / 75$ & 245 & 87 & 1423 \\
\hline $1953 / 54$ & 5 & 13 & 1284 & $1975 / 76$ & 234 & 90 & 1426 \\
\hline $1954 / 55$ & 5 & 16 & 1292 & $1976 / 77$ & 210 & 101 & 1428 \\
\hline $1955 / 56$ & 4 & 19 & 1299 & $1977 / 78$ & 218 & 114 & 1431 \\
\hline $1956 / 57$ & 3 & 27 & 1306 & $1978 / 79$ & 219 & 132 & 1432 \\
\hline $1957 / 58$ & 6 & 30 & 1314 & $1979 / 80$ & 230 & 143 & 1432 \\
\hline $1958 / 59$ & 18 & 28 & 1321 & $1980 / 81$ & 242 & 159 & 1432 \\
\hline $1959 / 60$ & 28 & 30 & 1329 & $1981 / 82$ & 250 & 156 & 1432 \\
\hline $1960 / 61$ & 34 & 28 & 1336 & $1982 / 83$ & 247 & 169 & 1432 \\
\hline $1961 / 62$ & 44 & 33 & 1344 & $1983 / 84$ & 261 & 196 & 1432 \\
\hline $1962 / 63$ & 56 & 37 & 1352 & $1984 / 85$ & 256 & 206 & 1432 \\
\hline $1963 / 64$ & 68 & 21 & 1361 & $1985 / 86$ & 243 & 204 & 1432 \\
\hline $1964 / 65$ & 87 & 40 & 1369 & $1986 / 87$ & 224 & 226 & 1432 \\
\hline $1965 / 66$ & 102 & 46 & 1377 & $1987 / 88$ & 235 & 242 & 1432 \\
\hline $1966 / 67$ & 119 & 50 & 1385 & $1988 / 89$ & 228 & 255 & 1432 \\
\hline $1967 / 68$ & 141 & 53 & 1393 & $1989 / 90$ & 254 & 263 & 1432 \\
\hline $1968 / 69$ & 157 & 60 & 1402 & $1990 / 91$ & 272 & 315 & 1432 \\
\hline $1969 / 70$ & 180 & 63 & 1410 & $1991 / 92$ & 271 & 315 & 1432 \\
\hline $1970 / 71$ & 197 & 63 & 1418 & $1992 / 93$ & 259 & 295 & 1432 \\
\hline $1971 / 72$ & 211 & 66 & 1418 & & & & \\
\hline
\end{tabular}

Appendix II. Numbers of elk in 1798-1993.

(1) Numbers of elk (as censused by snowtracking) in 1798-1935. Data from Jarocki 1830, Karcov 1903, Hartman 1939, and Miłkowski 1970, 1982. To calculate densities, numbers of elk were divided by the area of BPF $\left(1250 \mathrm{~km}^{2}\right)$.

\begin{tabular}{|c|c|c|c|c|c|c|c|c|c|}
\hline Yеаг & $N$ elk & Year & $N$ elk & Year & $N$ elk & Year & $N$ elk & Year & $N$ elk \\
\hline 1798 & 125 & 1893 & 460 & 1899 & 730 & 1905 & 340 & 1919 & 0 \\
\hline 1830 & rare & 1894 & 404 & 1900 & 700 & 1906 & 250 & 1928 & 0 \\
\hline 1850 & rare & 1895 & 490 & 1901 & 700 & 1907 & 222 & 1935 & 0 \\
\hline 1890 & 375 & 1896 & 500 & 1902 & 450 & 1908 & 144 & & \\
\hline 1891 & 535 & 1897 & 545 & 1903 & 370 & 1914 & 58 & & \\
\hline 1892 & 430 & 1898 & 660 & 1904 & 392 & 1915 & 50 & & \\
\hline
\end{tabular}


(2) Data on elk in 1946-1993 from game inventories conducted in the Polish and Belarussian parts of BPF, and calculated total numbers of elk in the whole Forest. Polish part: boldface type - results of drive censuses, which are close to absolute numbers; italics - snowtracking (a single count during winter) and/or assessment based on year round observations, known harvest quotas, measures of other wortality and reproduction rate; figures in italics are, on average, 2 times lower than absolute numbers, as shown by field testing of the census methods (Pucek et al. 1975). Little data are available on elk in Biatowieza National Park. In 1957-1961, censuses conducted there by snowtracking recorded no elk. In 1987, 0.05 elk tracks $\mathrm{km}^{-1}$ day $^{-1}$ were recorded by Jędrzejewski et al. (1992), which is equivalent to $3 \mathrm{elk}$ in the whole BNP (Priklonsky's method, described in Appendix III; mean daily movement distance of elk $1.37 \mathrm{~km}$, after Timofeeva 1974). In 1992, 7 elk were recorded in BNP by snowtracking in the entire area, but drive censuses done on $11.2 \mathrm{~km}^{2}$ in 1991 and 1992 did not record any elk. Thus, elk occurring in BNP constituted from 0 to $4 \%$ of the whole population only. So, except for the two years with data available, in calculating the total number of elk in BPF, we did not attempt to correct for animals living in BNP. Belarussian part of BPF: roman type - results of snowtracking with double count (on two days) to improve detectability; the numbers may be somewhat underestimated in comparison to the absolute numbers. ? - no data. Total numbers of elk in BPF: sum of numbers in the Polish part (snowtracking indices multiplied by 2 or absolute numbers obtained by drive censuses) and numbers in the Belarussian part. Densities ( $/ \mathrm{km}^{2}$, shown in Fig. 4) were calculated using the area of BPF listed in Appendix I.

\begin{tabular}{|c|c|c|c|c|c|c|c|}
\hline Year & $\begin{array}{l}N \text { elk in the } \\
\text { Polish part }\end{array}$ & $\begin{array}{c}N \text { elk in the } \\
\text { Belarussian } \\
\text { part }\end{array}$ & $\begin{array}{l}\text { Total } N \\
\text { in BPF }\end{array}$ & Year & $\begin{array}{l}N \text { elk in the } \\
\text { Polish part. }\end{array}$ & $\begin{array}{c}N \text { elk in the } \\
\text { Belarussian } \\
\text { part }\end{array}$ & $\begin{array}{l}\text { Total } N \\
\text { in BPF }\end{array}$ \\
\hline 1946 & 0 & 2 & 2 & 1970 & 7 & 40 & 54 \\
\hline 1947 & 0 & 2 & 2 & 1971 & 12 & 77 & 101 \\
\hline 1948 & 0 & 4 & 4 & 1972 & 18 & 73 & 109 \\
\hline 1949 & 0 & 5 & 5 & 1973 & $2 I$ & 60 & 102 \\
\hline 1950 & 0 & 9 & 9 & 1974 & 22 & 70 & 114 \\
\hline 1951 & 0 & 7 & 7 & 1975 & 35 & 73 & 143 \\
\hline 1952 & 0 & 9 & 9 & 1976 & 49 & 73 & 171 \\
\hline 1953 & 0 & 9 & 9 & 1977 & 44 & 110 & 198 \\
\hline 1954 & 0 & 11 & 11 & 1978 & 55 & 99 & 209 \\
\hline 1955 & 0 & 31 & 31 & 1979 & 33 & 112 & 178 \\
\hline 1956 & 0 & 34 & 34 & 1980 & 36 & 98 & 170 \\
\hline 1957 & 2 & 32 & 36 & 1981 & 44 & 110 & 198 \\
\hline 1958 & $I$ & 19 & 21 & 1982 & 67 & 138 & 272 \\
\hline 1959 & 0 & 33 & 33 & 1983 & 73 & 112 & 258 \\
\hline 1960 & 0 & 41 & 41 & 1984 & 45 & 157 & 247 \\
\hline 1961 & 0 & 56 & 56 & 1985 & 42 & 128 & 212 \\
\hline 1962 & 0 & 60 & 60 & 1986 & 38 & 220 & 296 \\
\hline 1963 & 0 & $?$ & $?$ & 1987 & $29(+3$ in $\mathrm{BNP})$ & 198 & 259 \\
\hline 1964 & 0 & $?$ & $?$ & 1988 & 35 & 209 & 279 \\
\hline 1965 & 0 & $?$ & $?$ & 1989 & 39 & $?$ & $?$ \\
\hline 1966 & 0 & $?$ & $?$ & 1990 & 66 & 186 & 318 \\
\hline 1967 & 3 & 27 & 33 & 1991 & 203 & 104 & 307 \\
\hline 1968 & 3 & 43 & 49 & 1992 & $54(+7$ in $\mathrm{BNP})$ & 115 & 176 \\
\hline 1969 & 3 & 62 & 68 & 1993 & 75 & 125 & 200 \\
\hline
\end{tabular}


Appendix III. Numbers of red deer in 1750-1993.

(1) Numbers of red deer in 1750-1940, after Brincken 1828, Karcov 1903, Yurkevich 1941, Shostak 1978, and Milkowski 1970, 1982. In 1890-1895, deer were censused by snowtracking, and in 1896-1914 by snowtracking and counts at feeding sites. Rapid increase of numbers in 1891-1896 was mainly due to release of enclosure-bred deer to the wild. To calculate densities $\left(N / \mathrm{km}^{2}\right.$, shown in Fig. $4)$, the numbers were divided by $1250 \mathrm{~km}^{2}$.

\begin{tabular}{|c|c|c|c|c|c|c|c|c|c|}
\hline Year & $N$ red deer & Year & $N$ red deer & Year & $N$ red deer & Year & $N$ red deer & Year & $N$ red deer \\
\hline$\sim 1750$ & $50-60$ & 1894 & 373 & 1901 & 2600 & 1908 & 4769 & 1928 & 210 \\
\hline 1800 & 0 & 1895 & 665 & 1902 & 2500 & 1910 & 5000 & 1935 & 687 \\
\hline 1889 & 0 & 1896 & 717 & 1903 & 2530 & 1914 & 6800 & 1939 & 1700 \\
\hline 1890 & 4 & 1897 & 849 & 1904 & 2935 & 1915 & 3000 & 1940 & 900 \\
\hline 1891 & 28 & 1898 & 1046 & 1905 & 3500 & 1916 & 1769 & & \\
\hline 1892 & 200 & 1899 & 1742 & 1906 & 3750 & 1917 & 1473 & & \\
\hline 1893 & 250 & 1900 & 2100 & 1907 & 5054 & 1919 & few dozen & & \\
\hline
\end{tabular}

(2) Data on red deer in 1946-1993 from game inventorjes conducted in the Polish and Belarussian parts, and calculated total numbers of red deer in the whole Forest. Polish part of BPF: boldface type - results of drive censuses, which are close to absolute numbers; italics - snowtracking (a single count during winter) and/or assessment based on year round observations, known harvest quotas, measures of other mortality and reproduction rate. Figures in italies are on average 2.6 times $(\mathrm{SE}=0.183$, $\mathrm{CV}=17.6 \%$ ) lower than absolute numbers, as shown by six sets of testing conducted in BPF: by Sablina (1955) in 1949 (ratio of snowtracking to drive census results 1:3.00), Pucek et al. (1975) in 1969,1971 , and 1973 (ratios $1: 2.86,1: 2.47$ and $1: 1.73$ ). L. Milkowski (unpubl) in 1991 (1:2.52), and Jędrzejewska et al. (1994) and the staff of BNP in 1992 (1:2.72). Thus, for calculation of the numbers of red deer in the whole BPF, results of snowtracking in the Polish part were multiplied by 2.6 . For years with no data $(1947-1949,1951-1955,1968,1970)$, estimates of numbers were reconstructed based on a highly significant correlation between the numbers of red deer in the exploited forests of the Polish part $(N \mathrm{P})$ and in the Belarussian part $\left(N_{\mathrm{B}}\right)$ in 1946-1980: $N \mathrm{P}=621.364+0.678 \mathrm{X}, n=24$ years, $R^{2}=0.672, p<0.0001\left(N_{\mathrm{P}}\right.$ were estimates of numbers already multiplied by 2.6 ). Standard error of prediction was, on average, $13 \%$ (range $5-21 \%$ ) of the reconstructed numbers of deer. Białowieża National Park: Roman type - snowtracking censuses with 1-4 censuses during each winter; boldface type - drive censuses. Numbers of red deer in BNP ( $\left.N_{\mathrm{BNP}}\right)$ were significantly correlated with those in the exploited forests of the Polish part: $\log _{\mathrm{ge}}\left(N_{\mathrm{BPN}}\right)=4.031+0.001 N_{\mathrm{P}}, n=5$ years, $R^{2}=0.898, p=0.014$. This equation, however, could not have been used for reconstructing numbers of red deer in BNP, because data points were clumped in two groups: around very low and very high densities. Instead, we calculated that, on average, deer numbers in $\mathrm{BNP}$ made $18 \%(\mathrm{SD}=5$ ) of those in the exploited forests of the Polish part, and we used this estimate for all years with no data on deer in BNP. Belarussian part: roman type - results of snowtracking with double count (on two consecutive days) to improve detectability (part of the series was published earlier by Shostak 1978); the numbers may be somewhat underestimated in comparison to the absolute numbers. Total number of red deer in BPF was calculated as the sum of: (1) censused or reconstructed numbers of deer in the exploited forests of the Polish part, (2) censused or reconstructed numbers in BNP, and (3) numbers in the Belarussian part. To obtain densities $\left(N / \mathrm{km}^{2}\right)$, the numbers were divided by the area of BPF listed in Appendix I. ? - no data and reconstruction not possible. Blank spaces - lack of data but reconstruction was passible. 


\begin{tabular}{|c|c|c|c|c|c|c|c|c|c|}
\hline \multirow[t]{2}{*}{ Year } & \multicolumn{2}{|c|}{$\begin{array}{c}N \text { red deer in the } \\
\text { Polish part }\end{array}$} & \multirow{2}{*}{$\begin{array}{l}N \text { red deer } \\
\text { in the } \\
\text { Belarussian } \\
\text { part }\end{array}$} & \multirow{2}{*}{$\begin{array}{c}\text { Total } N \\
\text { red deer } \\
\text { in BPF }\end{array}$} & \multirow[t]{2}{*}{ Year } & \multicolumn{2}{|c|}{$\begin{array}{l}N \text { red deer in the } \\
\text { Polish part }\end{array}$} & \multirow{2}{*}{$\begin{array}{l}N \text { red deer } \\
\text { in the } \\
\text { Belarussian } \\
\text { part }\end{array}$} & \multirow{2}{*}{$\begin{array}{c}\text { Total } N \\
\text { red deer } \\
\text { in BPF }\end{array}$} \\
\hline & $\begin{array}{l}\text { Exploited } \\
\text { forests }\end{array}$ & BNP & & & & $\begin{array}{l}\text { Exploited } \\
\text { forests }\end{array}$ & BNP & & \\
\hline 1946 & 290 & & 380 & 1270 & 1970 & & & 2090 & 4540 \\
\hline 1947 & & & 274 & 1232 & 1971 & 1420 & & 2290 & 3966 \\
\hline 1948 & & & 310 & 1298 & 1972 & $?$ & & 2430 & $?$ \\
\hline 1949 & & & 360 & 1388 & 1973 & 1435 & & 2290 & 3983 \\
\hline 1950 & 228 & & 510 & 1210 & 1974 & 775 & & 2100 & 4478 \\
\hline 1951 & & & 680 & 1971 & 1975 & 760 & & 2120 & 4452 \\
\hline 1952 & & & 770 & 2135 & 1976 & 827 & & 2120 & 4657 \\
\hline 1953 & & & 560 & 1753 & 1977 & 1145 & & 2500 & 6013 \\
\hline 1954 & & & 570 & 1771 & 1978 & 965 & & 2200 & 5161 \\
\hline 1955 & & & 680 & 1971 & 1979 & 930 & & 3260 & 6113 \\
\hline 1956 & 341 & & 760 & 1807 & 1980 & 1051 & & 2050 & 5275 \\
\hline 1957 & 256 & 107 & 540 & 1313 & 1981 & 1310 & & 2654 & 6364 \\
\hline 1958 & 380 & 103 & 700 & 1791 & 1982 & 1340 & & 2260 & 6055 \\
\hline 1959 & 430 & & 820 & 2139 & 1983 & 1121 & & 2360 & 5535 \\
\hline 1960 & 495 & & 900 & 2419 & 1984 & 1043 & & 2833 & 5787 \\
\hline 1961 & 584 & 202 & 1100 & 2820 & 1985 & 920 & & 3048 & 5653 \\
\hline 1962 & 671 & 143 & 1250 & 3138 & 1986 & 765 & & 2780 & 4946 \\
\hline 1963 & 774 & & 1330 & 3704 & 1987 & 1041 & & 2566 & 5514 \\
\hline 1964 & 846 & & 1600 & 4196 & 1988 & 1030 & & 2065 & 4982 \\
\hline 1965 & 776 & & 1700 & 4081 & 1989 & 875 & & $?$ & $?$ \\
\hline 1966 & 798 & & 1630 & 4078 & 1990 & 892 & & 1660 & 4186 \\
\hline 1967 & 821 & & 2880 & 5399 & 1991 & 2755 & 540 & 1620 & 4915 \\
\hline 1968 & & & 2550 & 5377 & 1992 & 1575 & 670 & 1720 & 3965 \\
\hline 1969 & 2900 & & 2650 & 6072 & 1993 & 1650 & & 2230 & 4177 \\
\hline
\end{tabular}

(3) Snowtracking censuses of red deer in Bialowieża National Park. Snowtracking conducted by A. Kawecki and co-workers in 1957-1962 in BNP yielded the numbers of ungulates calculated as the difference of incoming and leaving tracks in each forest compartment $(1066 \times \mathbf{1 0 6 6} \mathrm{m})$. Additionally, we had at our disposal the detailed field maps of their censuses, and we calculated the mean index $N$ tracks km${ }^{-1}$ day $^{-1}$ for each census. According to the method by Priklonsky (1965), this index ( $N_{\mathrm{t}}$ ) can be used to calculate densities $D\left(N / \mathrm{km}^{2}\right) . N_{\mathrm{t}}$ is multiplied by a constant 1.57 to obtain the total length $(L)$ of trails of a given animal species laid on an average square kilometer during one day. $L$ divided by the average daily movement distance (DMD) of an animal gives the number of animals present per $1 \mathrm{~km}^{2}$. The rationale of Priklonsky's method is that an animal moves along any curve within a circular home range. The constant $1.57(=1 / 2 \pi)$ is the average length of animal trail inside a square of a side $=1$, provided that each side of the square is crossed once. The accuracy of Priklonsky's method critically depends on the correct value of the daily movement distance of a given species in a given area. In BNP, we had censuses where both the tracking index $\left(N_{t}\right)$ and density $(D)$ where known, so we derived the DMD values from those data and used them to calculate the density for other years, when only $N_{\mathrm{t}}$ were available. The application of Priklonsky's method to the snowtracking of red deer in BNP showed that the daily movement distance of red deer was on average $1.54 \mathrm{~km}$ (SD $=0.3 \mathrm{I}$ ). This conformed to the values given by Sablina $(1955 ; 1.85 \mathrm{~km}$ on average, but one extreme movement of $18.8 \mathrm{~km}$ excluded) and Gordiyuk $(1985 ; 1.44 \mathrm{~km})$. The data are also in accordance with the results of concurrent drive and snowtracking censuses conducted in Slowinski National Park ( $N$ Poland) by Dzięciolowski et al. (1995). In their study, snowtracking index 14.0 tracks $\mathrm{km}^{-1} \mathrm{day}^{-1}$ was equivalent to 9.2 red deer $/ \mathrm{km}^{2}$. In BNP, densities of red deer calculated by 
Priklonsky's method in 1959 and 1987 (marked by ${ }^{\mathrm{R}}$ ) were compared to those reconstructed in part (2) (ie numbers in BNP as $18 \%$ of numbers in the exploited forests; given in parentheses). The difference between the two estimates were $2 \%$ and $21 \%$.

\begin{tabular}{lccc}
\hline Date of snowtracking & $N$ tracks km $\mathrm{km}^{-1} \mathrm{~d}^{-1}$ & Density $\left(N / \mathrm{km}^{2}\right)$ & Reconstructed DMD $(\mathrm{km})$ \\
\hline 28 January 1957 & 2.724 & 2.25 & 1.90 \\
25 January 1958 & 2.032 & 2.36 & 1.35 \\
22 February 1958 & 3.048 & 2.95 & 1.62 \\
24 February 1958 & 1.633 & 1.83 & 1.40 \\
21 March 1958 & 0.992 & 1.54 & 1.01 \\
16 January 1959 & 4.076 & $4.15^{\mathrm{R}}$ & \\
20 January 1959 & 2.580 & $2.63^{\mathrm{R}}$ & \\
28 January 1959 & 4.676 & $4.77^{\mathrm{R}}$ & \\
24 February 1959 & 4.882 & $5.00^{\mathrm{R}}$ & \\
Mean for 1959 & 4.054 & $4.13^{\mathrm{R}}(4.23)$ & \\
14 January 1961 & 4.835 & 4.25 & 1.79 \\
15 March 1962 & 3.295 & 3.01 & 1.72 \\
March 1987 & 7.660 & $7.81^{\mathrm{R}}(9.47)$ & \\
\hline
\end{tabular}

Appendix IV. Numbers of roe deer in 1890-1993.

(1) Numbers of roe deer in 1890-1940. Data from Karcov 1903, Yurkevich 1941, and Milkowski 1982. In 1890-1895 roe deer were censused by snowtracking, only, so the numbers are underestimated. In 1986-1914, besides snowtracking, counts at winter feeding sites were done annually, thus the estimates of abundance are more reliable. To calculate densities ( $N$ roe deer $/ \mathrm{km}^{2}$, shown in Fig. 4 ), the numbers were divided by $1250 \mathrm{~km}^{2}$.

\begin{tabular}{|c|c|c|c|c|c|c|c|c|c|}
\hline Year & $N$ roe deer & Year & $N$ roe deer & Year & $N$ roe deer & Year & $N$ roe deer & Year & $N$ roe deer \\
\hline 1890 & 541 & 1896 & 1345 & 1902 & 5000 & 1908 & 5382 & 1935 & 2400 \\
\hline 1891 & 729 & 1897 & 1690 & 1903 & 4560 & 1909 & 3473 & 1939 & 2938 \\
\hline 1892 & 434 & 1898 & 2178 & 1904 & 5495 & 1914 & 4966 & 1940 & 1500 \\
\hline 1893 & 685 & 1899 & 2960 & 1905 & 6000 & 1915 & 3000 & & \\
\hline 1894 & 835 & 1900 & 4500 & 1906 & 4300 & 1916 & 1063 & & \\
\hline 1895 & 959 & 1901 & 5100 & 1907 & 5329 & 1928 & 2000 & & \\
\hline
\end{tabular}

(2) Data on roe deer in 1946-1993 from game inventories conducted in the Polish and Belarussian parts and calculated total numbers of roe deer in the whole BPF. Polish part: boldface type - results of drive censuses which are close to absolute numbers. Italies in parentheses (1946-1968) snowtracking (a single count during winter) and/or assessment based on year round observations, known harvest quotas, measures of other mortality and reproduction rate. These figures are heavily underestimated and were not used for calculating the total population size in BPF. The pilot drive census of roe deer in the exploited forests of the Polish part conducted in 1968 showed that customary snowtracking yielded the numbers of roe deer 8 times lower than real numbers recorded by drive census (Mikkowski 1969). Nonetheless, the indices of numbers from 1946-1968 correctly showed the trend in population dynamics of roe deer; they are significantly correlated with those in the Belarussian part ( $n=13$ years, $r=0.79, p<0.01$ ). Italies $(1974-1990)$ - snowtracking (a single count during winter) and/or assessment based on year round observations, known harvest quotas, measures of other mortality and reproduction rate. These figures are based on a few years of experience in concurrent drive censuges and snowtracking (conducted in 1969, 1971 and 1973). In effect, the detectability of tracks increased. Snowtracking estimates from 1974-1990 are, on average, 2.9 times 
$(\mathrm{SE}=0.238, \mathrm{CV}=18.4 \%)$ lower than absolute numbers, as shown by five sets of testing conducted in BPF: by Sablina (1955) in 1949 (ratio of snowtracking to drive census results $1: 2.5$ ), Pucek et al. (1975) in 1969, 1971, and 1973 (ratios 1:2.94, 1:3.50 and 1:2.23), and Jędrzejewska et al. (1994) and the staff of BNP in 1992 (1:3.3). Data on roe deer numbers in the exploited forests of the Polish part in 1946-1968, 1970 and 1972 were reconstructed based on a highly significant correlation between the numbers of roe deer in the exploited forests of the Polish part ( $N \mathrm{p})$ and in the Belarussian part $\left(N_{\mathrm{B}}\right)$ in 1969-1980: $N_{\mathrm{P}}=-123.467+2.151 X, n=10$ years, $R^{2}=0.845, p=0.0002\left(N_{\mathrm{P}}\right.$ were snowtracking estimates of numbers already multiplied by 2.9 or results of drive censuses). In the reconstructed numbers, the average standard error of prediction was $15 \%$ of roe deer numbers (From $6 \%$ at high numbers to $53 \%$ at very low ones). The reconstructed numbers for 1946-1968 are, on average, 5.25 times (SD $=1.8$ ) higher than the game wardens estimates. Bialowieża National Park: roman type - snowtracking with 1-4 counts each winter; boldface type - drive censuses. The densities of roe deer were always very low in BNP (see also part 3 of this Appendix). In 1991-1992, when drive censuses were conducted, roe deer inhabiting BNP formed merely $4-5 \%$ of the combined numbers of roe deer in the Belarussian part and the exploited forests of the Polish part. Thus, except for years with data from BNP available, we did not attempt to correct the total number of roe deer for the lacking estimates from BNP. Belarussian part: roman type - results of snowtracking with double count (on two days) to improve detectability; the numbers may be somewhat underestimated in comparison to the absolute numbers. Total numbers of roe deer in BPF were calculated as the sum of deer numbers (censused or reconstructed) in the Polish and Belarussian parts. Densities $\left(N / \mathrm{km}^{2}\right)$ were calculated using the area of BPF listed in Appendix I. ? - no data and reconstruction not possible. Blank spaces - lack of data but reconstruction was possible.

\begin{tabular}{|c|c|c|c|c|c|c|c|c|c|}
\hline \multirow[t]{2}{*}{ Year } & \multicolumn{2}{|c|}{$\begin{array}{c}N \text { roe deer in the } \\
\text { Polish part }\end{array}$} & \multirow{2}{*}{$\begin{array}{l}N \text { roe deer } \\
\text { in the } \\
\text { Belarussian } \\
\text { part }\end{array}$} & \multirow{2}{*}{$\begin{array}{l}\text { Total } N \\
\text { roe deer } \\
\text { in BPF }\end{array}$} & \multirow[t]{2}{*}{ Year } & \multicolumn{2}{|c|}{$\begin{array}{c}N \text { roe deer in the } \\
\text { Polish part }\end{array}$} & \multirow{2}{*}{$\begin{array}{c}N \text { roe deer } \\
\text { in the } \\
\text { Belarussian } \\
\text { part }\end{array}$} & \multirow{2}{*}{$\begin{array}{l}\text { Total } N \\
\text { roe deer } \\
\text { in BPF }\end{array}$} \\
\hline & $\begin{array}{l}\text { Exploited } \\
\text { forests }\end{array}$ & BNP & & & & $\begin{array}{l}\text { Exploited } \\
\text { forests }\end{array}$ & $\mathrm{BNP}$ & & \\
\hline 1946 & $(420)$ & & 547 & 1600 & 1970 & & & 620 & 1830 \\
\hline 1947 & & & 497 & 1443 & 1971 & 1120 & & 570 & 1690 \\
\hline 1948 & & & 371 & 1046 & 1972 & & & 610 & 1799 \\
\hline 1949 & & & 480 & 1389 & 1973 & 1040 & & 800 & 1840 \\
\hline 1950 & $(140)$ & & 670 & 1988 & 1974 & 550 & & 690 & 2285 \\
\hline 1951 & & & 850 & 2555 & 1975 & 505 & & 690 & 2155 \\
\hline 1952 & & & 850 & 2555 & 1976 & 500 & & 850 & 2300 \\
\hline 1953 & & & 710 & 2114 & 1977 & 850 & & 900 & 3365 \\
\hline 1954 & & & 750 & 2240 & 1978 & 620 & & 880 & 2678 \\
\hline 1955 & & & 550 & 1610 & 1979 & 584 & & 1070 & 2764 \\
\hline 1956 & & & 480 & 1389 & 1980 & 621 & & 820 & 2621 \\
\hline 1957 & & & 330 & 916 & 1981 & 760 & & 772 & 2976 \\
\hline 1958 & $(150)$ & 22 & 270 & 749 & 1982 & 695 & & 920 & 2936 \\
\hline 1959 & $(210)$ & 15 & 550 & 1625 & 1983 & 662 & & 986 & 2906 \\
\hline 1960 & $(230)$ & & 660 & 1956 & 1984 & 701 & & 1372 & 3405 \\
\hline 1961 & $(250)$ & 32 & 750 & 2272 & 1985 & 675 & & 1367 & 3325 \\
\hline 1962 & $(261)$ & 19 & 850 & 2574 & 1986 & 615 & & 1482 & 3266 \\
\hline 1963 & $(410)$ & & 1000 & 3027 & 1987 & 698 & 32 & 1418 & 3474 \\
\hline 1964 & $(505)$ & & 1100 & 3343 & 1988 & 855 & & 1142 & 3622 \\
\hline 1965 & $(524)$ & & 1030 & 3122 & 1989 & 740 & & $?$ & $?$ \\
\hline 1966 & $(598)$ & & 1100 & 3343 & 1990 & 845 & & 923 & 3374 \\
\hline 1967 & $(578)$ & & 1800 & 5548 & 1991 & 2500 & 176 & 1060 & 3736 \\
\hline 1968 & $(526)$ & & 1650 & 5075 & 1992 & 2495 & 128 & 1050 & 3673 \\
\hline 1969 & 4170 & & 1950 & 6120 & 1993 & 1490 & & 1140 & 2630 \\
\hline
\end{tabular}


(3) Snowtracking censuses of roe deer in Bialowieża National Park, conducted by A. Kawecki and co-workers in 1957-1962. Based on their data, we calculated the densities according to Priklonsky's method (see description in Appendix III). The reconstructed daily movement distance of roe deer was, on average, $1.20 \mathrm{~km}(\mathrm{SD}=0.29$ ). Using this value, we calculated the densities of roe deer in 1959 and 1987 (marked by ${ }^{R}$ ). Vereshchagin and Rusakov (1979) reported that daily movement distance of roe deer can vary from 0.5 to $10.5 \mathrm{~km}$.

\begin{tabular}{lccc}
\hline Date of snowtracking & $N$ tracks k m $\mathrm{d}^{-1}$ & Density $\left(N / \mathrm{km}^{2}\right)$ & Reconstructed DMD (km) \\
\hline 28 January 1957 & 0.454 & 0.46 & 1.54 \\
25 January 1958 & 0.424 & 0.67 & 0.99 \\
22 February 1958 & 0.268 & 0.40 & 1.05 \\
24 February 1958 & 0.287 & 0.34 & 1.34 \\
21 March 1958 & 0.167 & $0.22^{\mathrm{R}}$ & \\
16 Jaruary 1959 & 0.277 & $0.36^{\mathrm{R}}$ & \\
20 January 1959 & 0.325 & $0.43^{\mathrm{R}}$ & \\
28 January 1959 & 0.156 & $0.20^{\mathrm{R}}$ & \\
24 February 1959 & 0.232 & $0.30^{\mathrm{K}}$ & \\
Mean for 1959 & 0.248 & $0.32^{\mathrm{R}}$ & \\
14 January 1961 & 0.633 & 0.67 & 1.47 \\
15 March 1962 & 0.206 & 0.40 & 0.81 \\
March 1987 & 0.520 & $0.68^{\mathrm{R}}$ & \\
\hline
\end{tabular}

Appendix V. Numbers of wild boar in 1890--1993.

(1) Numbers of wild boar in 1890-1940. Data from Bobrovskii 1863, Karcov 1903, Yurkevich 1941, and Milkowski 1970, 1982. In 1890-1893 wild boar were censused by snowtracking, and in 1896-1914 snowtracking was supplemented by counts at winter feeding sites. Because wild boar do not utilise feeding sites as readily as deer or bison, these counts were unlikely to improve the detectability of boar. Thus, based on experiences in censusing wild boar in 1946-1990, these numbers (written in italics) were multiplied by 1.7 (mean ratio of drive censuses to snowtracking results; see part 2 of this Appendix) to get more reliable estimates. Also, the results of monarchial hunts in 1890-1902 (Table 1) evidenced that wild boar proportion in the ungulate community could have been higher than that shown by inventories. To calculate densities (N/km ${ }^{2}$, shown in Fig. 4$)$, the numbers (multiplied by 1.7 ) were divided by $1250 \mathrm{~km}^{2}$.

\begin{tabular}{|c|c|c|c|c|c|c|c|c|c|}
\hline \multirow{2}{*}{$\frac{\text { Year }}{1890}$} & \multirow{2}{*}{$\frac{N \text { wild boar }}{329}$} & \multicolumn{2}{|c|}{ Year $N$ wild boar } & \multicolumn{2}{|c|}{ Year $N$ wild boar } & \multicolumn{2}{|c|}{ Year $N$ wild boar } & \multicolumn{2}{|c|}{ Year $N$ wild boar } \\
\hline & & 1897 & 1100 & 1902 & 1800 & 1907 & 1639 & 1928 & 250 \\
\hline 1891 & 900 & 1898 & 653 & 1903 & 1140 & 1908 & 1412 & 1935 & 1240 \\
\hline 1892 & 758 & 1899 & 750 & 1904 & 1033 & 1910 & 1842 & 1939 & 1900 \\
\hline 1893 & 890 & 1900 & 1500 & 1905 & 1500 & 1914 & 2320 & 1940 & $1 \pm 10$ \\
\hline 1896 & 1026 & 1901 & 2000 & 1906 & 1200 & 1917 & 440 & & \\
\hline
\end{tabular}

(2) Data on wild boar in 1946-1993 from game inventories conducted in the Polish and Belarussian parts, and cafculated total numbers of wild boar in the whole Forest. Polish part: boldface type - results of drive censuses, which are close to absolute numbers. Italies - snowtracking (a single count during winter) and/or assessment based on year round observations, known harvest quotas, measures of other mortality and reproduction rate. These figures are on average 1.7 times $(\mathrm{SE}=0.197, \mathrm{CV}=25.1 \%$ ) lower than absolute numbers, as shown by five sets of testing conducted in BPF: by Sablina (1955) in 1949 (ratio of snow tracking to drive census results 1:2.00), Pucek et al. (1975) in 1969, 1971, and 1973 (ratios 
1:1.86, 1:1.11 and 1:1.53), and Jędrzejewska et al. (1994) and the staff of BNP in 1992 (1:2.24). Thus, for calculation of total numbers of wild boar, results of snowtracking in the Polish part were multiplied by 1.7. For years with no data (1947-1949, 1951-1957), estimates of numbers were reconstructed based on a highly significant correlation between the numbers of wild boar in the exploited forests of the Polish part $\left(N_{\mathrm{P}}\right)$ and in the Belarussian part $\left(N_{\mathrm{B}}\right)$ in 1946-1980: $N_{\mathrm{P}}=372.183+0.419 N_{\mathrm{B}}, n=25$ years, $R^{2}=$ $0.521, p=0.0007\left(N_{\mathrm{P}}\right.$ were snowtracking estimates of numbers already multiplied by 1.7 or results of drive censuses). Standard error of prediction was, on average, 16\% (range 6-26\%) of the reconstructed numbers of wild boar. Białowieza National Park: roman type - snowtracking censuses with 1-4 censuses during each winter; boldface type - drive censuses. Numbers of wild boar in BNP (NBNP) were significantly correlated with those in the exploited forests of the Polish part $\left(N_{\mathrm{P}}\right)$ : $\operatorname{Loge}_{\mathrm{B}}\left(N_{\mathrm{BPN}}\right)=3.1+$ $0.002 N_{P_{1}} n=6$ years, $R^{2}=0.812, p=0.014$. This equation was used for reconstructing the numbers of wild boar in BNP whenever field census data for exploited forests were available. Belarussian part: roman type - results of snowtracking with double count (on two days) to improve detectability; the numbers may be somewhat underestimated in comparison to the absolute numbers. Numbers of wild boar in the whole BPF were calculated as a sum of (1) censused or reconstructed numbers of wild boar in the exploited forests of the Polish part, (2) numbers in BNP, and (3) numbers in the Belarussian part. To obtain densities $\left(\mathrm{N} / \mathrm{km}^{2}\right)$, total numbers were divided by the area of BPF listed in Appendix I. Index of acorn (oak seed) crop - percentages of the maximal annual purchase of acorns (50100 kg in 1982) from the local people, who gathered them in Bialowieza Forest District (exploited forests of the Polish part of $\mathrm{BPF}$ ). ? - no data and reconstruction not possible. Blank spaces - lack of data but reconstruction was possible.

\begin{tabular}{|c|c|c|c|c|c|}
\hline \multirow[t]{2}{*}{ Year } & \multicolumn{2}{|c|}{$\begin{array}{l}N \text { wild boar in the } \\
\text { Polish part }\end{array}$} & \multirow{2}{*}{$\begin{array}{l}N \text { wild boar } \\
\text { in the } \\
\text { Belarussian } \\
\text { part }\end{array}$} & \multirow{2}{*}{$\begin{array}{c}\text { Total } N \\
\text { wild boar } \\
\text { in BPF }\end{array}$} & \multirow{2}{*}{$\begin{array}{l}\text { Percentage } \\
\text { index of } \\
\text { acorn crop }\end{array}$} \\
\hline & $\begin{array}{l}\text { Exploited } \\
\text { forests }\end{array}$ & $\mathrm{BNP}$ & & & \\
\hline 1 & 2 & 3 & 4 & 5 & 6 \\
\hline 1946 & 265 & & 694 & 1174 & $?$ \\
\hline 1947 & & & 327 & 841 & $?$ \\
\hline 1948 & & & 506 & 1096 & $?$ \\
\hline 1949 & & & 723 & 1405 & $?$ \\
\hline 1950 & 230 & & 1068 & 1483 & $?$ \\
\hline 1951 & & & 510 & 1102 & $?$ \\
\hline 1952 & & & 1166 & 2036 & $?$ \\
\hline 1953 & & & 894 & 1649 & $?$ \\
\hline 1954 & & & 403 & 949 & $?$ \\
\hline 1955 & & & 325 & 838 & $?$ \\
\hline 1956 & & & 310 & 817 & $?$ \\
\hline 1957 & & 64 & 176 & 690 & $?$ \\
\hline 1958 & 490 & 52 & 332 & 1217 & 98.3 \\
\hline 1959 & 510 & 98 & 478 & 1443 & 10.9 \\
\hline 1960 & 550 & & 1325 & 2364 & 0 \\
\hline 1961 & 580 & 138 & 1370 & 2494 & $?$ \\
\hline 1962 & 530 & 64 & 1380 & 2345 & 26.6 \\
\hline 1963 & $62 I$ & & 1360 & 2560 & $?$ \\
\hline 1964 & 492 & & 1450 & 2366 & 46.8 \\
\hline 1965 & 297 & & 550 & 1088 & 1,6 \\
\hline 1966 & 450 & & 724 & 1567 & 8.7 \\
\hline 1967 & 500 & & 1250 & 2183 & 67.9 \\
\hline 1968 & 514 & & 2100 & 3063 & 0.6 \\
\hline 1969 & 1410 & & 2200 & 3980 & $?$ \\
\hline
\end{tabular}




\begin{tabular}{|c|c|c|c|c|c|}
\hline 1 & 2 & 3 & 4 & 5 & 6 \\
\hline 1970 & 340 & & 1360 & 1978 & $?$ \\
\hline 1970 & 340 & & 1360 & 1978 & $?$ \\
\hline 1971 & 610 & & 1549 & 2203 & $?$ \\
\hline 1972 & 505 & & 1378 & 2321 & $?$ \\
\hline 1973 & 1445 & & 1674 & 3525 & $?$ \\
\hline 1974 & 725 & & 1719 & 3182 & $?$ \\
\hline 1975 & 760 & & 1454 & 3016 & 9.4 \\
\hline 1976 & 742 & & 2121 & 3631 & 30.4 \\
\hline 1977 & 920 & & 2230 & 4351 & 0 \\
\hline 1978 & 900 & & 2396 & 4435 & 6.5 \\
\hline 1979 & 766 & & 2219 & 3798 & 0 \\
\hline 1980 & 769 & & 1600 & 3188 & 0 \\
\hline 1981 & 770 & & 2095 & 3686 & 0.1 \\
\hline 1982 & 655 & & 1910 & 3192 & 100 \\
\hline 1983 & 470 & & 2173 & 3044 & 0 \\
\hline 1984 & 927 & & 3286 & 5438 & $?$ \\
\hline 1985 & 805 & & 2573 & 4273 & 1.5 \\
\hline 1986 & 670 & & 2400 & 3718 & 15.5 \\
\hline 1987 & 739 & & 1571 & 3072 & 0 \\
\hline 1988 & 845 & & 1680 & 3514 & 4.8 \\
\hline 1989 & 790 & & $?$ & $?$ & 16.2 \\
\hline 1990 & 935 & & 1680 & 3868 & 0 \\
\hline 1991 & 1780 & 850 & 1620 & 4250 & 0 \\
\hline 1992 & 1040 & 280 & 1265 & 2585 & 14.0 \\
\hline 1993 & I 230 & & 1112 & 2571 & 14.0 \\
\hline
\end{tabular}

(3) Snowtracking censuses of wild boar in Bialowieża National Park, conducted by A. Kawecki and co-workers in 1957-1962. Based on their data, we calculated the densities according to Priklonsky's method (description in Appendix III). The reconstructed daily movement distance (DMD) of wild boar was, on average, $1.69 \mathrm{~km}$ ( $\mathrm{SD}=0.40$ ). Using this value, we calculated the densities of wild boar in 1959 and 1987 (marked by ${ }^{\mathrm{R}}$ ). When compared to those calculated by the method described in part (2) (given in parentheses), they appeared to differ by $6 \%$ and $13 \%$, only. DMD calculated by us is shorter than 3.96 and $3.4 \mathrm{~km}$, the values given by Sablina (1955) and Rusakov and Timofeeva (1984), respectively.

\begin{tabular}{lccc}
\hline Date of snowtracking & $N$ tracks km $\mathrm{km}^{-\mathbf{i}}$ & Density $\left(\mathrm{N} / \mathrm{km}^{2}\right)$ & Reconstructed DMD $(\mathrm{km})$ \\
\hline 28 January 1957 & 1.745 & 1.35 & 2.03 \\
25 January 1958 & 1.226 & 1.49 & 1.29 \\
22 February 1958 & 1.208 & 0.88 & 2.16 \\
24 February 1958 & 0.906 & 1.24 & 1.15 \\
2 March 1958 & 0.741 & 0.76 & 1.55 \\
16 January 1959 & 2.559 & $2.38^{\mathrm{R}}$ & \\
20 January 1959 & 1.958 & $1.82^{\mathrm{R}}$ & \\
28 January 1959 & 2.343 & $2.18^{\mathrm{R}}$ & \\
24 February 1959 & 3.366 & $3.13^{\mathrm{R}}$ & \\
Mean for 1959 & 2.556 & $2.38^{\mathrm{R}}(2.08)$ & \\
14 January 1961 & 3.789 & 2.90 & 2.05 \\
15 March 1962 & 1.386 & 1.35 & 1.61 \\
March 1987 & 6.580 & $6.11^{\mathrm{R}}(5.77)$ & \\
\hline
\end{tabular}


Appendix VI. Numbers of introduced fallow deer in 1890-1935.

Data on free-liwing population of fallow deer from Karcov (1903) and Milkowski (1982). In 1890-1914. censuses of fallow deer were done by snowtracking and were supplemented (since 1894-1896) by counts at winter feeding sites. Rapid increase of deer numbers soon after introduction was mainly due to release of enclosure-bred deer to the wild. To calculate densities $\left(N / \mathrm{km}^{2}\right)$, the numbers were divided by $1250 \mathrm{~km}^{2}$.

\begin{tabular}{|c|c|c|c|c|c|c|c|}
\hline Year & $N$ fallow deer & Year & $N$ fallow deer & Year & $N$ fallow deer & Year & $N$ fallow deer \\
\hline 1889 & 0 & 1896 & 118 & 1903 & 618 & 1916 & 209 \\
\hline 1890 & 12 & 1897 & 189 & 1904 & 645 & 1919 & 5 \\
\hline 1891 & 11 & 1898 & 310 & 1905 & 750 & 1920 & 0 \\
\hline 1892 & 25 & 1899 & 451 & 1906 & 800 & 1928 & 0 \\
\hline 1893 & 30 & 1900 & 600 & 1907 & 1250 & 1935 & 0 \\
\hline 1894 & 32 & 1901 & 740 & 1908 & 1209 & & \\
\hline 1895 & 96 & 1902 & 700 & 1914 & 1488 & & \\
\hline
\end{tabular}

Appendix VII. Indices of cattle abundance in 1700-1992.

Data from Jarocki 1830, Genko 1902-1903, Karcov 1903, Wróblewski 1927, Hedemann 1939, Więcko 1963, Faliński 1968, S. Kujawiak (pers. comm.), forest inventories, management plans and Letopis Prirody (Nature Chronicle) of the Belarussian part of BPF, and forest inventory and management plan of Bialowieża Forest District, Poland.

(1) Descriptive indices of the extent of cattle grazing in BPF.

\begin{tabular}{|c|c|}
\hline Year & Information \\
\hline 1700 & Cattle officially allowed on $250-300 \mathrm{~km}^{2}$ of BPF \\
\hline $1820-1830$ & $\begin{array}{l}\text { Pasturing in forests forbidden; cattle allowed on meadows in the valleys of forest rivers } \\
\text { and around villages }\end{array}$ \\
\hline 1846 & Private fields and meadows within BPF borders covered $60.22 \mathrm{~km}^{2}$ \\
\hline 1861 & Private fields and meadows within BPF borders covered $135.67 \mathrm{~km}^{2}$ \\
\hline 1869 & $\begin{array}{l}16 \text { villages located outside BPF got rights to pasture their cattle in meadows and forests } \\
\text { of BPF }\end{array}$ \\
\hline 1973 & Pasturing of cattle in the Polish part of BPF forbidden \\
\hline
\end{tabular}


(2) Indices of cattle numbers. Roman type - official statistics of cattle numbers. Italics - numbers of cattle calculated based on total annual income from pasturing and average charges paid by cattle owners per head of cattle. ${ }^{a}$ data for the Belarussian part; ${ }^{b}$ data for the Polish part; ${ }^{\mathbf{c}}$ official data for the Bialowieża Forest District $\left(67.15 \mathrm{~km}^{2}\right)$; these figures are underestimates but they correctly show the trend of decline; " figures approximate; in 1971, the commune of Bialowieza located in the central part of BPF pastured $450-460$ cattle, which constituted about $1 / 3$ of the total number of cattle in BPF.

\begin{tabular}{|c|c|c|c|}
\hline Year & $\begin{array}{l}\text { Area grazed by cattle }\left(\mathrm{km}^{2}\right) \\
\text { (in parentheses: total area } \\
\text { for which data are } \\
\text { available) }\end{array}$ & Number of cattle & $\begin{array}{l}\text { Total income to } \\
\text { BPF headquarters } \\
\text { from pasturing } \\
\text { (in roubles) }\end{array}$ \\
\hline 1875 & $456.67(1250)$ & & \\
\hline 1886 & & 5500 & 3701 \\
\hline 1887 & & 6250 & 4206 \\
\hline 1888 & & 6348 & 4273 \\
\hline 1889 & $474.73(1250)$ & 7330 & 4934 \\
\hline 1900 & $286.40(1250)$ & 7440 & 6943 \\
\hline 1901 & & 6590 & 6149 \\
\hline 1902 & & 6330 & 5909 \\
\hline 1909 & $260.00(1250)$ & 8342 & $?$ \\
\hline $1951^{\mathrm{d}}$ & $48.00 \quad(718)$ & 415 & no charges \\
\hline $1952^{\mathrm{i}}$ & $73.00 \quad(725)$ & 657 & $\pi$ \\
\hline $1953^{\mathrm{a}}$ & $84.25 \quad(733)$ & 753 & ${ }^{n}$ \\
\hline $1954^{\#}$ & $71.00 \quad(740)$ & 631 & $\pi$ \\
\hline $1955^{\sharp}$ & $140.00 \quad(748)$ & 1068 & $"$ \\
\hline $1964^{\mathrm{b}}$ & $112.50 \quad(580)$ & & $n$ \\
\hline $1964^{\mathrm{c}}$ & $10.42(67.15)$ & 176 & $"$ \\
\hline $1965^{\mathrm{c}}$ & $10.56(67.15)$ & 185 & $n$ \\
\hline $1966^{\mathrm{c}}$ & $8.26(67.15)$ & 108 & $n$ \\
\hline $1967^{\mathrm{c}}$ & $5.80(67.15)$ & 86 & $"$ \\
\hline 1971 & & $1300-1400^{d}$ & $"$ \\
\hline $1992^{n}$ & $68.72(874)$ & 594 & $n$ \\
\hline
\end{tabular}

